\title{
La mission Labraunda 2013
}

Rapport préliminaire

Olivier Henry, Ayşe Güliz Bilgin Altınöz, Jesper Blid, Ömür Dünya Çakmaklı, Andrew Dufton, Agneta Freccero, Linda Gosner, Ragnar Hedlund, Pascal Lebouteiller, Vasilica Lungu, Felipe Rojas, Fredrik Tobin, Baptiste Vergnaud et Andrew Waters

\section{(2) OpenEdition}

1 Journals

Édition électronique

URL : http://journals.openedition.org/anatoliaantiqua/317

DOI : $10.4000 /$ anatoliaantiqua.317

Éditeur

IFEA

Édition imprimée

Date de publication : 1 janvier 2014

Pagination : 255-325

ISBN : 9782362450136

ISSN : $1018-1946$

Référence électronique

Olivier Henry, Ayşe Güliz Bilgin Altınöz, Jesper Blid, Ömür Dünya Çakmaklı, Andrew Dufton, Agneta Freccero, Linda Gosner, Ragnar Hedlund, Pascal Lebouteiller, Vasilica Lungu, Felipe Rojas, Fredrik Tobin, Baptiste Vergnaud et Andrew Waters, «La mission Labraunda 2013 », Anatolia Antiqua [En ligne], XXII | 2014, mis en ligne le 30 juin 2018, consulté le 18 décembre 2020. URL : http://

journals.openedition.org/anatoliaantiqua/317 ; DOI : https://doi.org/10.4000/anatoliaantiqua.317 


\section{ANATOLIA ANTIQUA ESKI ANADOLU}

\section{XXII}

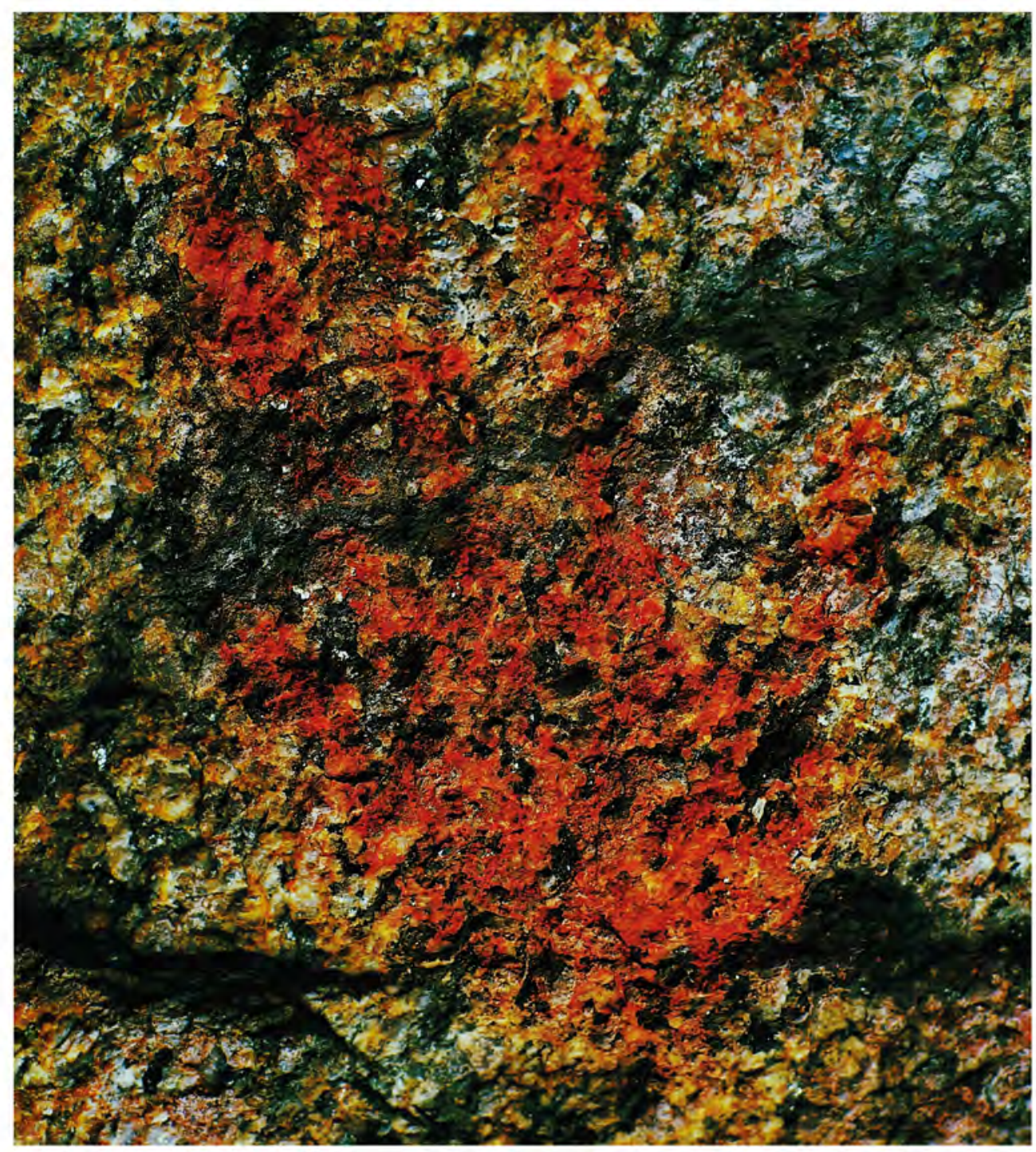

INSTITUT FRANÇAIS D'ETUDES ANATOLIENNES GEORGES-DUMEZIL CNRS USR 3131

DE BOCCARD 


\section{TABLE DES MATIERES}

Emma BAYSAL,

A preliminary typology for beads from the Neolithic and Chalcolithic levels of Barcın Höyük

William ANDERSON, Jessie BIRKETT-REES, Michelle NEGUS CLEARY,

Damjan KRSMANOVIC et Nikoloz TSKVITINIDZE,

Archaeological survey in the South Caucasus (Samtskhe-Javakheti, Georgia):

Approaches, methods and first results

Eda GÜNGÖR ALPER,

Hellenistic and Roman period ceramic finds from the Balatlar Church excavations in

Sinop between 2010-2012

Ergün LAFLI et Gülseren KAN ŞAHİN,

Hellenistic ceramics from Southwestern Paphlagonia

Oğuz TEKIN,

Weights of Lysimachea from the Tekirdağ Museum and various collections

Oğuz TEKIN,

Three weights of Lampsacus

Julie DALAISON et Fabrice DELRIEUX,

La cité de Néapolis-Néoclaudiopolis : histoire et pratiques monétaires

Martine ASSENAT et Antoine PEREZ,

Amida 4. Constance II et Amida

Sencan ALTINOLUK et Nilüfer ATAKAN,

Abrasax: A magical gem in the Istanbul Archaeological Museums

Bahadır DUMAN,

A group of local production Middle Byzantine period pottery from Tripolis:

'Micaceous White Painted Ware'

CHRONIQUES DES TRAVAUX ARCHEOLOGIQUES EN TURQUIE, 2014

Jean-Charles MORETTI,

avec la collaboration de Nicolas BRESCH, Isabel BONORA, Jean-Jacques MALMARY et

Olivier RISS,

Claros, le Temple d'Apollon : travaux réalisés en 2013

Suat ATEŞLIER,

On the excavations of the Zeus Temple of Alabanda 
Olivier HENRY,

avec Ayşe Güliz BİLGIN ALTINÖZ, Jesper BLID, Ömür Dünya ÇAKMAKLI, Andrew DUFTON, Agneta FRECCERO, Linda GOSNER, Ragnar HEDLUND, Pascal LEBOUTEILLER,

Vasilica LUNGU, Felipe ROJAS, Fredrik TOBIN, Baptiste VERGNAUD et

Andrew WATERS,

La mission Labraunda 2013 - Rapport préliminaire

Dominique BEYER, Isabelle CHALIER, Françoise KIRNER,

Françoise LAROCHE-TRAUNECKER et Aksel TIBBET,

Zeyve Höyük - Porsuk. Rapport préliminaire sur la campagne 2013

Çĭ̆dem MANER,

Preliminary report on the first season of the Konya-Ereğli (KEYAR) survey 2013 


\section{Olivier HENRY* \\ avec Ayşe Güliz BİLGİN ALTINÖZ, Jesper BLID, Ömür Dünya ÇAKMAKLI, Andrew DUFTON, Agneta FRECCERO, Linda GOSNER, Ragnar HEDLUND, Pascal LEBOUTEILLER, Vasilica LUNGU, Felipe ROJAS, Fredrik TOBIN, Baptiste VERGNAUD et Andrew WATERS}

\section{LA MISSION LABRAUNDA 2013 - RAPPORT PRELIMINAIRE}

La mission Labraunda 2013 s'est déroulée du 05 août au 27 septembre 2013. La date de début, initialement prévue le 22 juillet, a dû être reportée à deux reprises suite à des difficultés administratives. Les opérations 2013 se sont déroulées sous l'égide du Musée archéologique de Milas, en cette période de transition de la direction du site, et nous sommes particulièrement redevable à Mr Ali Sinan Özbey, directeur du Musée, et à son représentant Suleyman Özgen pour l'aide et le soutien qu'ils nous ont apportés tout au long de la campagne.

La mission de cette année fut probablement la plus intense depuis les larges opérations de fouille des années 1970, puisqu'elle s'est déroulée avec 39 archéologues et 17 ouvriers plus une équipe de 11 personnes travaillant au projet de conservation/restauration de l'Andron A. Le budget particulièrement conséquent de cette année a pu être monté sur la base d'une collaboration internationale et en faisant intervenir des partenariat publics et privés ${ }^{1}$.

Cette année nous avons tenté, avec succès, de mener trois actions de front : fouille, documentation, restauration et mise en valeur. Les fouilles ont concerné pour l'essentiel des zones qui se trouvent soit à l'intérieur soit à proximité immédiate de l'aire sacrée. Les programmes de documentation que nous avons mis en place depuis l'année dernière tentent de mettre à plat nos connaissances du site et des fouilles anciennes, qu'il s'agisse du matériel mis au jour ou de structures. Les conservations ont porté sur le matériel architectural en marbre et sur l'Andron A d'Idrieus. Enfin, la mise en valeur a été particulièrement efficace cette année et a porté à la fois sur une meilleure sécurisation du site, une meilleure information concernant ses vestiges et un déblayage des remblais de fouilles anciennes.

Les résultats de cette année ont été extrêmement satisfaisants. L'équipe internationale et interdisciplinaire que nous avons mise en place a fonctionné à plein rendement et offre de belles promesses pour l'avenir ${ }^{2}$. Le caractère international de cette équipe explique l'utilisation des langues françaises et anglaises dans le rapport qui suit.

*) IFEA-USR3131, Istanbul.

1) Nous tenons à remercier ici l'ensemble des partenaires qui ont participé, directement ou indirectement, au financement de la mission 2013: ESAN/Eczacibaşı, la fondation J.M. Kaplan, Labrandasällskapet, la municipalité de Milas, le Musée de Milas, la Vitterhetsakademien, le Ministère français des Affaires étrangères et du développement international, l'Université de Brown, le Swedish Research Institute in Istanbul, l'Université d'Uppsala, l'Institut Français d'Etudes Anatoliennes, Sven Kristensons resestipendium, The Royal Swedish Academy of Letters, History and Antiquities, A.W. Persson travel grants (Uppsala University), the Harald and Tonny Hagendahs memorial Foundation, The Helge Ax:son Johnson Foundation, Harald och Tonny Hagendahls minnesfond.

2) Les membres de l'équipe 2013 ont été (par ordre d'apparition sur le terrain): Olivier Henry, Ömür Çamakl1, Baptiste Vergnaud, Jesper Blid, Felipe Rojas, Andy Dufton, Linda Gosner, Marco Ziff, Laura Leddy, Christina DiFabio, Andrew Waters, Hilal Kuntuz, Ragnar Hedlund, İpek Dağlı, Melissa Cormier, Pascal Lebouteiller, Fredrik Tobin, Lars Karlsson, Agneta Freccero, Erika Andersson, Victoria Bly, Anna Enberg, Kanwal Quadri, Anna Plahn, Adam Justin-Moll, Pontus Hellström, Katerina Stathi, Cansu Erik, Mehmet Cam, İsmail Coğalan, Yasin Durnaoğlulları, Can Karavul, Vasilica Lungu, Güneș Sargüney, Merve Erkut, Célia Decalonne, Klara Borgström, Ömer Güngörmüş ; auxquels il faut ajouter l'équipe ayant travaillé à l'élaboration du projet de restauration de l'Andron : Kemal Gülcen, Tamer Topal, Ŭğurhan Akyüz, Ayşe Güliz Bilgin Altınöz, Neriman Şahin Güçhan, Göze Akoğlu, Yasemin Didem Aktaş Erdem, Suna Kabasakal Coutignies, Yavuz Kaya, Filiz Diri, Barış Erdil. 


\section{LES PROJETS DE RESTAURATION/CONSERVATION}

\subsection{Conservation project of Andron A: intervention proposals as a response to values and problems (par A.G. Bilgin Altınöz, METU)}

The Andron A, a monumental banquet hall built by Idrieus, is one of the most important remains of the archaeological site of Labraunda (Fig. 1). Since the re-discovery of Labraunda by the early excavations of the Swedish team in 1948, Andron A has been a central focus for both the field archaeologists as well as the visitors because of its exceptional state of preservation. As one of the most and first visible monumental building while approaching the site,

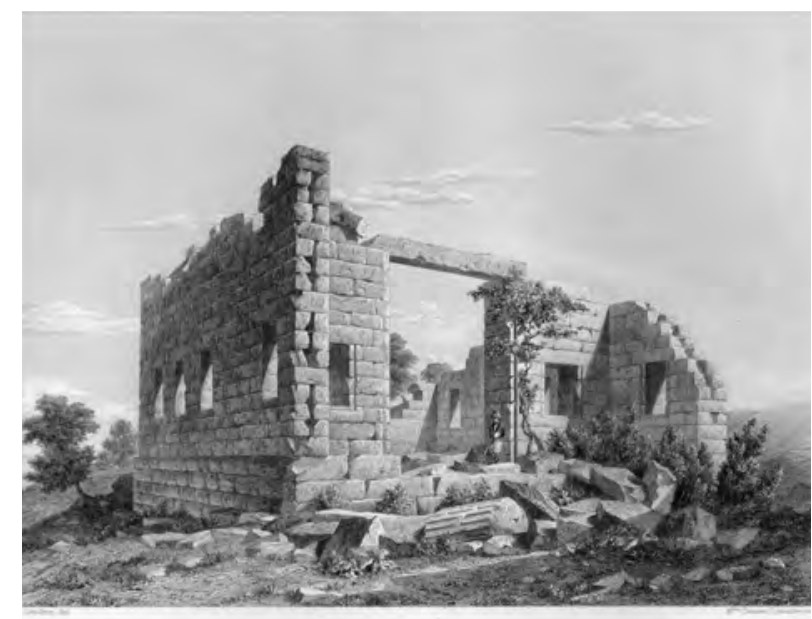

Fig. 1 : The 'image' of Andron A within its physical and natural context in 1840s in Eugène Landron's drawings (Philippe Le Bas, Voyage archéologique en Grèce et en Asie Mineure sous la direction de M. Philippe Le Bas (1842-1844). Planches de topographie, de sculpture et d'architecture, gravées d'après les dessins de E. Landron, publiées et commentées par Salomon Reinach, Paris 1888 : 47-48).

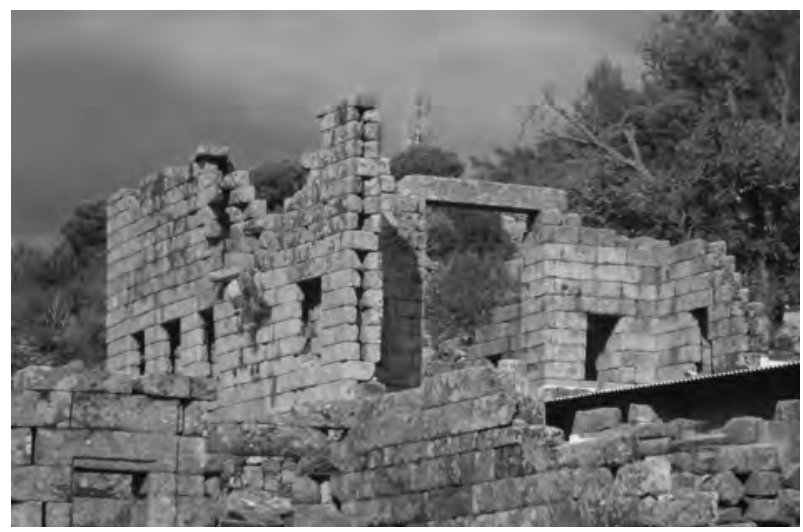

Fig. 2 : The 'image' of Andron A within its physical and natural context in 2012 (METU Project Team, 2012).

the image of Andron A has come to be a symbol for the site (Fig. 2). Due to its importance, since its discovery until today, the Andron A has been documented various times with different techniques.

Despite the fact that Andron A is still a partially unexcavated structure, due to various architectural, structural and material problems threatening the building and making it very fragile, there occurred an urgent need for an emergency conservation program. In this regard, a protocol between IFEA and METU was signed for the conservation project of Andron A, financially supported by the J.M. Kaplan Fund. The protocol covered research, documentation, analysis and laboratory studies, restitution and restoration projects, interim and final reports, technical documents for the implementation phase and program for monitoring and control after the implementation of the project. The project is led by a multidisciplinary team of specialists from METU in collaboration with the specialists from the archaeological team at Labraunda ${ }^{3}$. The project started in September 2012 and all the final documents and projects were sub-

3) The team is composed of the following members: A. Güliz Bilgin Altınöz [Asst. Prof. Dr., METU] Architect / Conservation Specialist, (Project Director); Suna Coutignies, [METU] Architect / Conservation Specialist; Filiz Diri [Specialist, METU] Architect / Conservation Specialist; Neriman Şahin Güçhan [Assoc. Prof. Dr., METU] Architect, Conservation Specialist (Consultant); Özgün Özçakır [Res. Asst., METU] Architect / Conservation Specialist; Leyla Etyemez [Res. Asst., METU] Architect / Conservation Specialist; Uğurhan Akyüz [Prof. Dr., METU] Civil Engineer; Barış Erdil [Res. Asst. Dr., Van 100. Yıl University] Civil Engineer; Tamer Topal [Prof. Dr., METU] Geological Engineer ; Göze Akoğlu [Asst. Prof. Dr., Mustafa Kemal University] Physicist, Specialist In Arhaeometry and Conservation; Yavuz Kaya [Res. Assist., METU] Geological Engineer; Kemal Gülcen [Specialist, METU] Cartographer, Photogrammetry Specialist; Pontus Hellström [Prof. Dr., Uppsala University, Department of Classical Archaeology and History of Ancient Period] Archaeologist; Thomas Thieme, [Dr.] Architect; Olivier Henry [Assoc. Prof. Dr., IFEA] Archaeologist, (Director of Labraunda Excavations]; Lars Karlsson [Prof. Dr., Uppsala University, Department of Classical Archaeology and History of Ancient Period] Archaeologist (Swedish Excavation Team Leader 2004-2012). All studies are prepared with the valuable help of each of the members of all the excavation team to whom we owe gratitude. 
mitted to IFEA as well as Muğla Regional Conservation Council for approval on June $2013^{4}$.

The conservation project for Andron A is prepared with a holistic approach considering all the architectural, geological, material, structural and contextual parameters. Consequently, architectural and contextual studies, geological and material studies, and structural studies are considered as the main tracks of the project all through the phases of research, survey, analysis and assessments. The outcomes of the studies of these tracks were supported and integrated with each other at the end of each phase as well as at the final stage while defining the conservation principles and interventions for Andron A.

The architectural research, survey, analysis and assessment track started with the documentation of the building together with its context ${ }^{5}$. The first phase of this was a metric and photographic documentation, which ended up with up-to-date measured drawings of the building and its nearby context. This provided a basis for the studies on the graphic restitution of the building, aiming at understanding the original building form and the changes occurring in time. The information coming from the excavation team and based on the archaeological evidences, measurements, documentations and observations at the site as well as the historical research and comparative studies were the main sources of information for restitution. Due to the fact that the archaeological research and excavations about Andron A have not been completed yet, the information about the building is also incomplete and hypothetic to a certain degree. Besides, as the Andrones in Labraunda are almost unique structures with no known totally similar and standing examples, it also becomes difficult to extract precise information from the comparative studies. Therefore, the restitution project had hypothetical or rather less reliable aspects. For this reason, the degrees of reliabilities were also shown over the restitution drawings. All in all, the restitution project helped to understand the possible original state of the building, keeping in mind that it can change in the future due to new findings together with a systematic archaeological excavation and research.

The outcomes of this track helped to define some of the intervention principles and criteria of the conservation project. Accordingly, the proposed conservation interventions should not prevent future interventions and excavations, thus they should be re-treatable. Besides, as the building is a still standing as a well-preserved and rare example of its type, its authenticity was considered as an important parameter. Thus the interventions were defined so as to have minimum intrusion on the original material, structure and details of the building and reversible as much as possible. Last but not least, due to the importance of the building for the site and its integrity with its context, Andron A cannot be regarded as an isolated building, but should be treated as part of an archaeological, previously sacred site and a broader cultural landscape that reflects a sense and spirit of the place. Therefore, the project on Andron A should aim at conservation, sustainability and the presentation of the building within its context, considering the balances within the site, site image and spirit of the whole site. As a result, the likely effects of interventions proposed by the project should not only be assessed while taking into account the building itself, but also as part of a whole.

The research, survey, analysis and assessment track on geology and materials started with the analysis of the geological aspects of the $\operatorname{area}^{6}$. These studies showed that Labraunda is within the first degree seismically active area. When a comparison between the state of the building in late 1940s with its current state is made, based on photographs taken during the early excavations, it can be seen that almost no recognizable change has occurred since then, even though important earthquakes happened in this region during this period. However, during the field survey, a systematic movement in south direction was observed in the stone blocks of different buildings at the site, possibly due to earthquake. Therefore, seismicity became one of the main parameter while considering the conservation project.

4) The architectural, geological, material, structural research, survey, analysis and assessments as well as the restitution project were completed in 2012. The outcomes of these studies were already published by myself in Henry et al. 2013, 310-322. The 2013 studies covered the final assessments. Based on these assessments the development of alternatives, and the preparation of the Restoration Project for Andron A including the interventions, their implementation processes and monitoring after implementations. As this article aims to cover the whole project, 2012 studies are re-mentioned in addition to 2013 studies.

5) The studies in this track, including the architectural survey, restitution project and restoration project, were made by Asst. Prof. Dr. A. Güliz Bilgin Altınöz, Cons. Arch. Suna Coutignies, Cons. Arch. Filiz Diri, Assoc. Prof. Dr. Neriman Şahin Güçhan. The measurings were made by Architectural Surveyor Kemal Gülcen and Cons. Arch. Filiz Diri. Prof. Dr. Pontus Hellström and Dr. Thomas Thieme contributed to the restitution project. Cons. Arch. Özgün Özçakır and Cons. Arch. Leyla Etyemez contributed during the preparation of the final drawings of the restoration project.

6) The studies in this track were conducted by Prof. Dr. Tamer Topal, Asst. Prof. Dr. Göze Akoğlu and Res. Asst. Yavuz Kaya. 


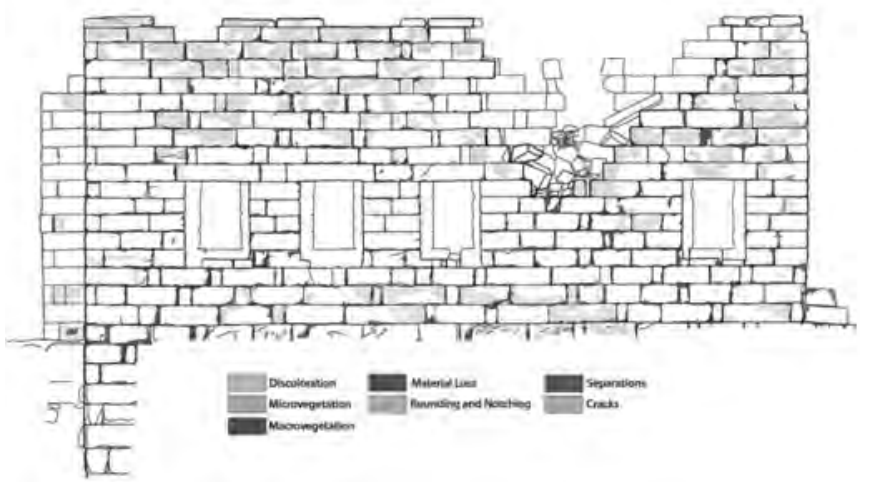

Fig. 3 : Mapping of visual weathering forms on south facade (C METU, 2012).

As a part of the geological and material studies, stone samples with no archaeological importance were collected for laboratory analysis. Density, sound velocity, porosity, XRD mineralogical analysis and petrographic analyzes by optical microscopy of thin sections were conducted over these samples, in order to define the physical and physico-mechanical properties of these rocks. It revealed that the building stones used in the Andron A are gneiss, with high unit weight, effective porosity, low water absorption and cation-exchange capacity. Hence, their field performances are good, as long as they are used horizontally parallel to their foliation planes and as long as their contact with water is controlled through good drainage. The observations during the site survey also proved that most of the material problems such as discoloration, flaking, surface relief, rounding and notching at the edges of the blocks and material loss in the upper parts of the building are due to repeated contact with rainwater from surfaces and from the top (Fig. 3).

Thereupon, providing water drainage and delimiting the water entry in between the gneiss blocks from the top or from surfaces of the walls have been among the main concerns of the conservation project. Besides, another common form of degradation is the loss of material by eruptions due to the effects of plant roots growing on the walls, which necessitated intervention. There are also micro vegetation such as fungi, algae and lichens. However, as no clear adverse effects of them could be visualized and as removing them is a destructive process causing loss of material from the surface, it is proposed not to intervene on them at the moment, but to monitor their effects on the stone walls in time.

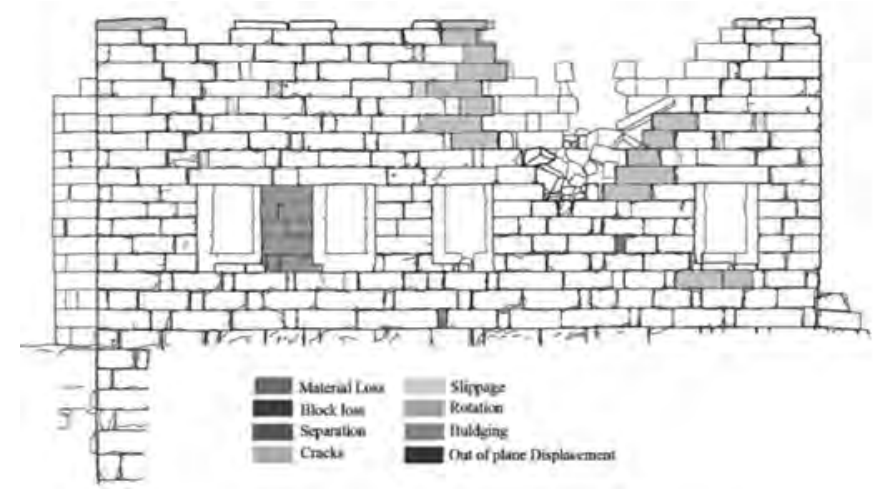

Fig. 4 : Mapping of structural problems on south facade (C METU, 2012).

The major conservation issue in Andron A is related to its structural stability. Thereupon, comprehensive understanding of the structural condition and of the structural damages became one of the major concerns and tracks of the project ${ }^{7}$. As the first stage of the structural studies, structural problems were detected during the site survey, which were then mapped on the measured drawings of the building. Accordingly, material loss, block loss, separation, slippage, rotation, bulging and out of plane displacement are the structural problems which can be visualized in Andron A (Fig. 4).

For further analysis and assessments of the structural behavior and problems of the building, a finite element model with a macro modeling approach was created based on the measured drawings (Fig. 5). The analysis over the model helped both understanding the current structural condition and behavior of the building as well as making projections about its future condition and behavior under different forces.

All these studies revealed that the main problem of the building is the out-of-plane movement under possible seismic forces acting in a north-south direction. The structural problems are mostly concentrated on the south wall, which is leaning towards the south. This leaning causes the separation of the two wall shells, which can be easily visualized through the recessed headers. There are also noticeable vertical cracks on the west wall and the back-wall of the pronaos due to the leaning of the south wall. In addition to this, on the upper part of the south wall a triangular area is totally destructed. Moreover, a horizontal bulging at the base part of the south wall can be visualized. Considering the seismic sen-

7) The track on structural studies including the structural survey, analysis, assessments and the development of proposals for strengthening, were conducted by Prof. Dr. Uğurhan Akyüz and Asst. Prof. Dr. Barış Erdil. Dr. Yasemin Didem Aktaş contributed to this track during the preliminary modeling stage. 


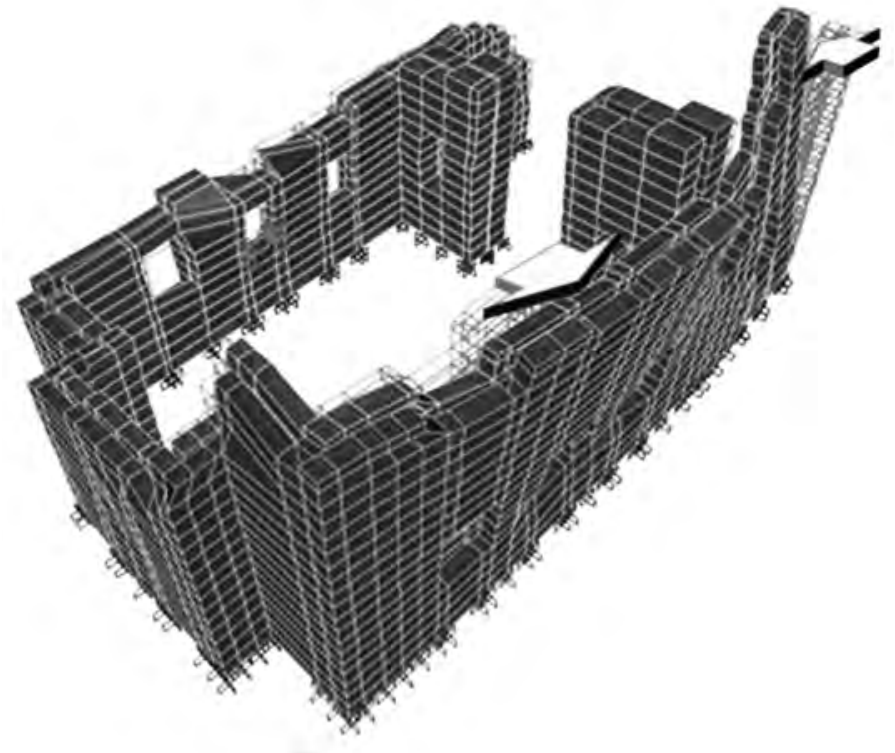

Fig. 5 : Finite element model of Andron A (C) METU, 2012).

sitivity of the site revealed by the geological studies, even with a small vibration, there is high risk of collapse of the south wall, which will affect the stability of the whole building. As a result of all these problems, the building becomes structurally fragile and open to further destruction. Thereupon, the major concern of the conservation project has been providing the structural stability and sustainability of the building by creating a regular force distribution, preventing the separation and decreasing the displacements associated with drifts, and increasing the stiffness of the south wall.

The procedure, approach, principles and the intervention criteria of the conservation project of $\mathrm{An}$ dron $\mathrm{A}$ are defined in consideration with the character, properties and problems of the building together with its context and in view of the international conservation principles and criteria ${ }^{8}$, which are defined as minimum intervention, reversibility, re-treatability, sustainability, authenticity, spirit of place, integrity, safety and stability.

As a next step, different alternatives were developed in order to provide the structural stability of the building. All of the alternatives were then assessed according to the settled conservation principles and criteria.
In this regard, the first alternative proposed strengthening by reconstructing the south wall. This requires the dismantling of the south wall block by block, and then reconstructing it by using the original stone blocks in their original places as much as possible. In this case, as the friction and integrity between the stone blocks will be lost due to dismantling, it will be necessary while re-constructing to increase the stiffness by using shear keys made of steel bars and longitudinal reinforcements. Therefore, each block would need to be connected with the adjacent ones by the help of longitudinal bars placed via epoxy injection into the holes that should be drilled in each block. Although this alternative does not disturb the 'image' of Andron A, the intervention itself is too invasive and not reversible. Besides, it needs a perfect workmanship, otherwise the end result can be a failure. All these remarks led us to discard this alternative.

Strengthening with channel profiles or with IPE profiles were two other alternatives. However, both of these interventions were neither minimum nor reversible, while they also were disturbing the image of the building and consequently the sense of place too much.

The fourth alternative considered strengthening the south wall with truss from exterior. In this alternative, there are no direct intervention on the wall itself and the whole process is non-destructive and reversible. However, this alternative would seriously disturb the 'image' of Andron A and the sense of place. Besides, if this alternative is realized then it cannot be possible to conduct further excavations outside the building, which surely will be necessary in the near future.

The fifth and last alternative aims at strengthening the wall with truss from the interior. Contrary to the previous one, this alternative is re-treatable; it will have a very small visual effect on the 'image' of $A n$ dron $\mathrm{A}$ and the sense of place from the outside. However from inside, there will be a visible steel structure. In this alternative, the steel structure will be connected to the wall through steel bars. Therefore, some slight destructive interventions are unavoidable, as holes are needed for steel bars. However, in order to make this intervention as minimum as possible the steel bars are located to pass through the joints in-between the stone blocks.

8) Main International documents referred to are: (1992) European Convention on the Protection of the Archaeological Heritage (revised), Council of Europe, Valetta; (1999) Burra Charter: Charter for the Conservation of Places of Cultural Significance, Australia ICOMOS, Burra; (2003) ISCARSAH Principles. ICOMOS Charter- Principles for the Analysis, Conservation and Structural Restoration of Architectural Heritage; (2008) Ename Charter: ICOMOS Charter for the Interpretation and Presentation of Cultural Heritage Sites, ICOMOS, Québec; (2008) Québec Declaration on the Preservation of the Spirit of Place, ICOMOS, Québec. 

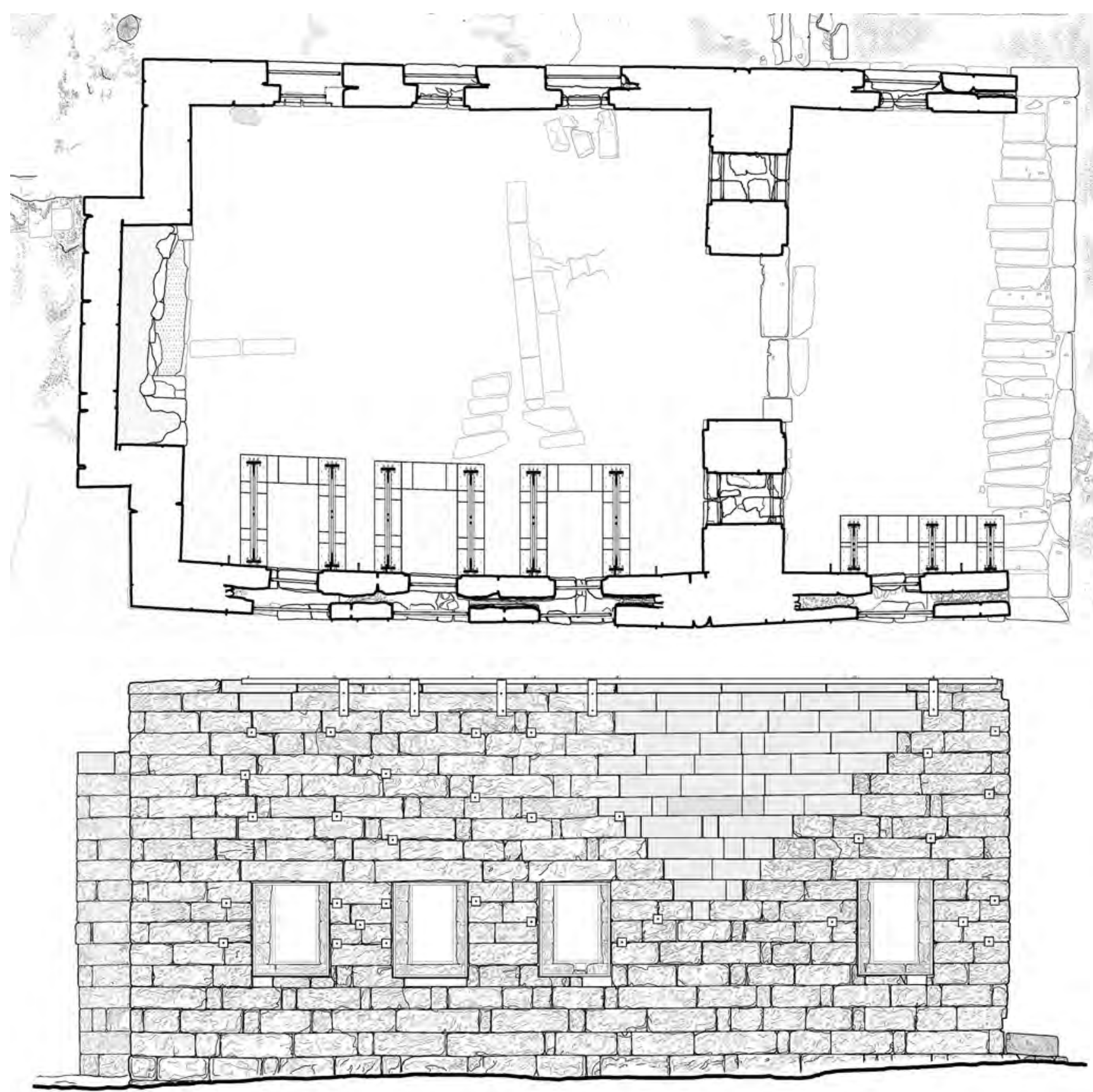

Fig. 6 : The restoration drawings: plan and south facade (C METU, 2013).

The assessment of all these alternatives denoted that none of them could totally fulfill all the defined conservation principles and criteria. Among all, the fifth alternative, which is strengthening with truss from the interior, is the most proper one. Therefore, the conservation project of Andron A is prepared according to this solution. The conservation project covered the restoration drawings as well as the presentation of the conservation interventions together with their detailed descriptions and implementation processes (Fig. 6).

Accordingly, conservation project covers the following interventions implemented in a sequence:

- doing the preparatory works for conservation interventions and conservation of the original floor plasters;

- supporting the south wall with a temporary scaffolding; 


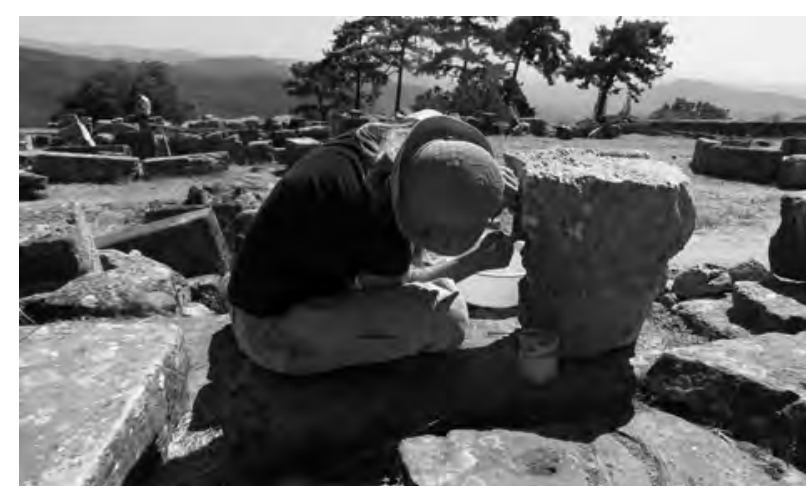

Fig. 7 : Cleaning of a corinthian capital from the north Stoa (photo : A. Freccero).

- taking down the unstable and unsafe stone blocks on the south façade; frames;

- supporting the window openings with steel

- filling the cracks and gaps on the walls with repair mortar;

- intervening to the macro vegetation;

- re-stabilizing the lost and deformed parts of the south and east walls by putting back the slipped or slided stones into their original places, changing the existing blocks in bad condition with new gneiss blocks and constructing the lost part of the south facade with gneiss stone blocks in order to provide the structural stability between the south wall and the back wall of the pronaos;

- constructing the steel truss strengthening system;

- capping the top of the walls in order to avoid water penetration in between the walls from the top.

This conservation project has not been an end, but it should be considered as a beginning of an ongoing process for conservation and sustainability of Andron A. Only after the implementation of this project, it will be possible to start the archaeological excavations which can reveal new evidences about the building. Then after, based on more solid data, the conservation project can be revised and new interventions can be proposed and implemented. Meanwhile, within this process a conservation and management plan for Labraunda should also be prepared, which will provide a holistic approach and an integrated consideration towards different excavations and conservation interventions taking place in different parts of the site.

\subsection{The Marble conservation at Labraunda}

(par A. Freccero, restauratrice indépendante)

During last year's campaign the conservator graduate and the two archaeologists participating were able only to stay at the site during one week and I worked on my own for the remaining two weeks. At the end of the period it was impossible to anticipate the situation for next year and therefore conservation was planned for one or two persons. Instead, the conservation group expanded and four students from the building conservation program at the University of Gotland joined the project. Erika Andersson, graduate of the conservation program at Gothenburg University, participated for the third time, now as my assistant. Conservation was carried through as a two-week stage. Traditional graphical and verbal documentation methods were part of the training, which in its practical part consisted of cleaning, consolidation, attachment of fragments, and preparation of stucco for infillings. Excursions to the archaeological sites at Iasos, Euromos, Stratonikeia and Lagina were part of the program, aiming at making the students familiar with the Mediterranean culture at different periods in antiquity, as well as looking at marble and discussing conservation methods and problems related to the different sites. We also visited antique quarries at Euromos and Iasos. Evaluation of previously made conservation was made during the first working day, as was the annual inspection of the test slab - the large slab on which a series of different consolidation substances were previously tested.

Conservation was concentrated to the North Stoa and the five Corinthian capitals of the colonnade that remain (Fig. 7). Two capitals had been prepared last year when they were treated with biocide, as was the large column drum at Andron B (Fig. 8). Two objects found in earth this year were cleaned and consolidated. One of these was a frail fragment of an anta capital, and the second was a large fragment of an architrave with inscription (inv. K81) at the South Propylaea. After being found and registered in 1949, the fragment had at some time fallen and been broken into two parts with the inscribed side in the earth. As the broken blocks were lifted the inscription was identified and placed to the left of the entrance of the gateway. A portion of the central part including some letters is missing (Fig. 9). A few minor rearrangements were made at the South Propylaea in connection with the replacement of the broken architrave. The first part of the left side of the architrave, inv. K4, was placed beside the inscribed part, and a fragment of the pediment positioned upon it. Further, the capital of the left anta was placed on an inscribed anta block, thereby approximately mirroring the arrangement on the right hand side, with the anta capital conserved in 2011. 


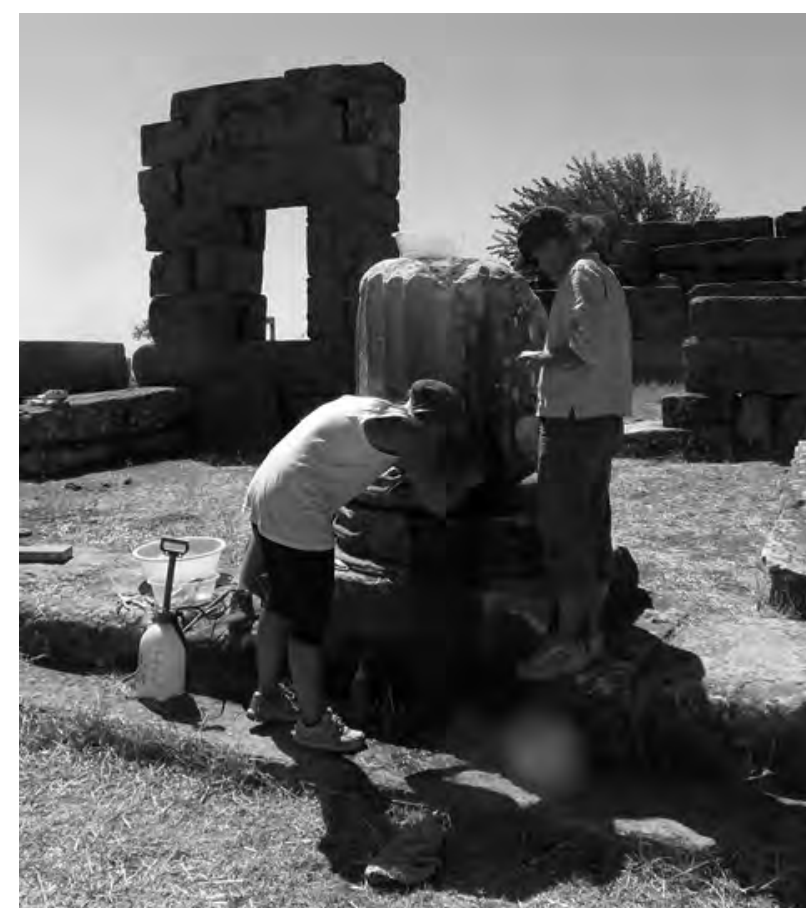

Fig. 8 : Cleaning of a column drum in pronaos of Andron B (photo : A. Freccero).

As mentioned in last year's report, the principle of conservation within this project has been to perform the minimum intervention needed with the lightest means possible. The goal was never to produce white artifacts but to clean and consolidate and, not to forget, to do regular maintenance interventions on conserved objects, such as brushing off soil and rinsing with spring water when needed.

One of the last days we made a survey to look at the items conserved and at the many objects in need of conservation, in order to discuss the selection of items for next year. This was intended as a practical part of conservation theory; we need to be aware of the impact of personal taste and preferences and should formulate our reasons for selecting one object instead of another for preservation in the near future. Selection may be due to the values we attach to objects of various kinds. Values may be historical such as inscriptions, artistic such as reliefs and finely cut decorations, but selection may otherwise be made by practical reasons such as treatments being possible to carry out in the limited time available, or aesthetic reasons such as the position of the object in the context, just to mention a few variables.

We do not know if the conservation group will be large or small next year. We do not either know the period of time, which may be two weeks or longer. Such uncertainties make planning difficult. If there is one person only, one week would be enough for maintenance and cleaning. A group of persons would create a team, and a team should preferably work together during a longer period, maybe four weeks. A team has the capacity of doing more complex interventions if there is enough time, and if the proper kinds of tools and materials are available. In any case, planning has to be done, and a biocide treatment one year before conservation is very efficient and does not harm the marble if conservation is not carried out. Therefore, this year we selected items that were not too problematic, of reasonable size, and close to each other in order to be able to create groups of persons working. Focus next year will be at the South Propylaea and/or the area of the Oikoi and the Temple of Zeus.

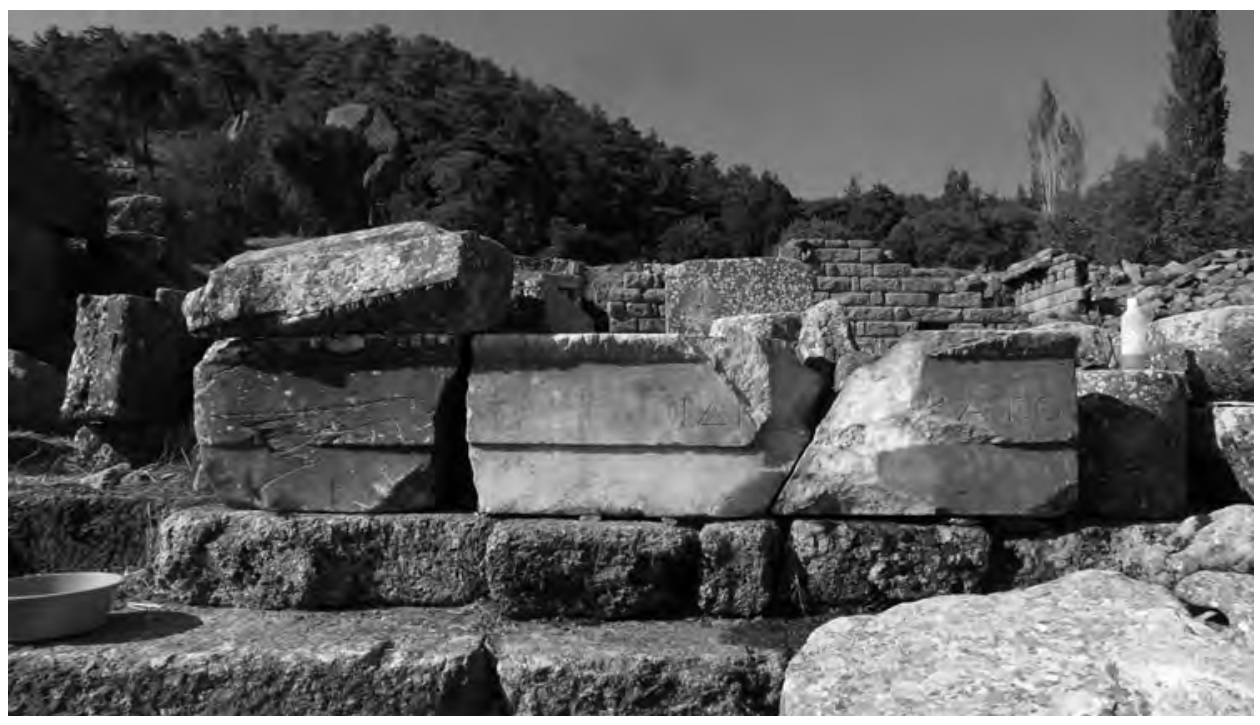

Fig. 9 : The architraval dedication of the south Propylon after cleaning (photo : A. Freccero). 


\section{LA MISE EN VALEUR DU SITE}

\subsection{Exposition Labraunda/Çomakdă̆}

\section{A Istanbul (Fig. 10)}

En 2010, l'équipe de fouille de Labraunda avait participé à l'organisation d'une exposition photographique ainsi qu'à la production d'un important catalogue consacré à Labraunda et sa région. Apres avoir voyagé en Scandinavie, l'exposition, inaugurée par Mr le Consul Général de France à Istanbul, Hervé Magrot,, a été présentée à l'Institut culturel français de Taksim (Istanbul) du 05 décembre 2012 au 12 janvier 2013.

\section{A Milas (Fig. 11)}

Suite au succès de la présentation de l'exposition à Taksim, nous avons décidé de monter cette exposition à Milas même, la ville la plus proche du site de Labraunda. L'exposition s'est déroulée du 17 au 31 mai 2013 et correspondait à la semaine du patrimoine en Turquie. Elle a été organisée en collaboration avec le Musée archéologique ainsi qu'avec la Mairie. L'inauguration s'est faite en présence du maire de Milas et du directeur du Musée archéologique.

\section{A Izmir}

L'exposition s'est ensuite déplacée plus au Nord pour être accrochée à l'Institut français culturel d'Izmir du 11 juillet au 28 août 2013, où elle a connu un grand succès, particulièrement grâce aux nombreux étudiants et touristes venus visiter la ville pendant les vacances d'été.

\subsection{Travaux sur le site}

\section{Nettoyage (Fig. 12)}

La mission 2013 a commencé par un nettoyage général du site. Cette année ce nettoyage, réalisé pendant 10 jours par 15 ouvriers, a largement dépassé les limites strictes du temenos et a permis de découvrir plusieurs nouvelles structures (voir notamment infra la section 3.3).

Mise aux normes des panneaux de signalisation et peinture

L'une de nos premières actions a été de remplacer les deux principaux panneaux de signalisation sur le site par une version mise à jour du plan du site et du texte qui tient compte des dernières découvertes. $\mathrm{Ce}$ remplacement était par ailleurs nécessaire pour répondre aux critères dictés par la direction générale du patrimoine (Fig. 13).
Un troisième panneau de très grande taille a été placé au cœur du site. Il ne vise pas seulement à informer sur les structures mais davantage sur l'histoire du sanctuaire dans son contexte régional et local (Fig. 14).

Enfin, l'ensemble des 18 panneaux de bâtiment ont été revus, réparés et leur cadre repeint lorsque cela était nécessaire.

Les trois grandes barrières en bois du site : à l'entrée, autour de la maison du gardien et au niveau des bains sud (voir section suivante) ont été entièrement repeintes.

\section{Sécurisation des sondages profonds}

Deux sondages profonds, l'un au niveau des bains sud et datant d'une quinzaine d'année, et l'autre au Nord du bâtiment hypostyle (voir infra la section 4.4) ont été sécurisés. Une barrière en bois interdit désormais l'accès au premier, tandis qu'une couverture métallique a été appliquée au-dessus du second (Fig. 15).

\section{Clôtures du site}

Dans le cadre de la mise en valeur du site, nous avons procédé à un grand réaménagement de la parcelle qui longe la route asphaltée au pied du site (voir infra la section 4.5). Cette parcelle est limitée au Nord par un très long mur de terrasse hellénistique et au Sud s'y trouvait un mur moderne en pierre sèche dont une grande section était effondrée. Nous avons supprimé ce dernier qui empêchait d'ailleurs de voir le long mur de terrasse et implanté une barrière de panneau métallique de plus de $110 \mathrm{~m}$ de long (Fig. 16). Cet aménagement permet aussi d'augmenter la visibilité du bâtiment hypostyle, situé à l'extrémité sud-est du site.

La zone occidentale du site a, elle aussi, été clôturée à l'aide d'un grillage, afin d'éviter que les troupeaux de vaches ne pénètrent à l'intérieur du temenos.

\section{Enlèvement des remblais de fouille et murs de parcelles}

Un des importants travaux réalisés cette année consistait en l'enlèvement de très larges remblais de fouille datant des années 1960. Ceux-ci avaient été déposés à l'entrée du site, devant le propylon sud dont il masquait les vestiges aux visiteurs (Fig. 17). Malgré la grande taille des remblais on n'a noté qu'une très faible quantité de matériel céramique 

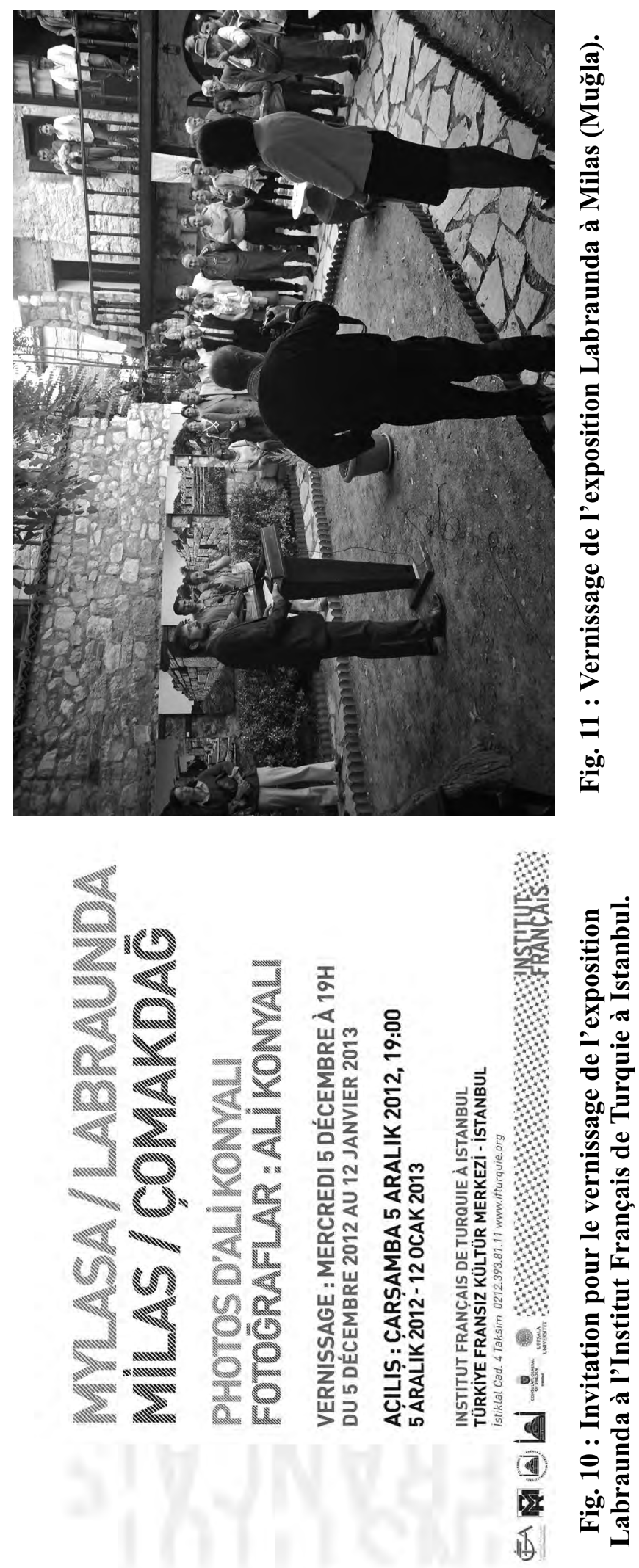

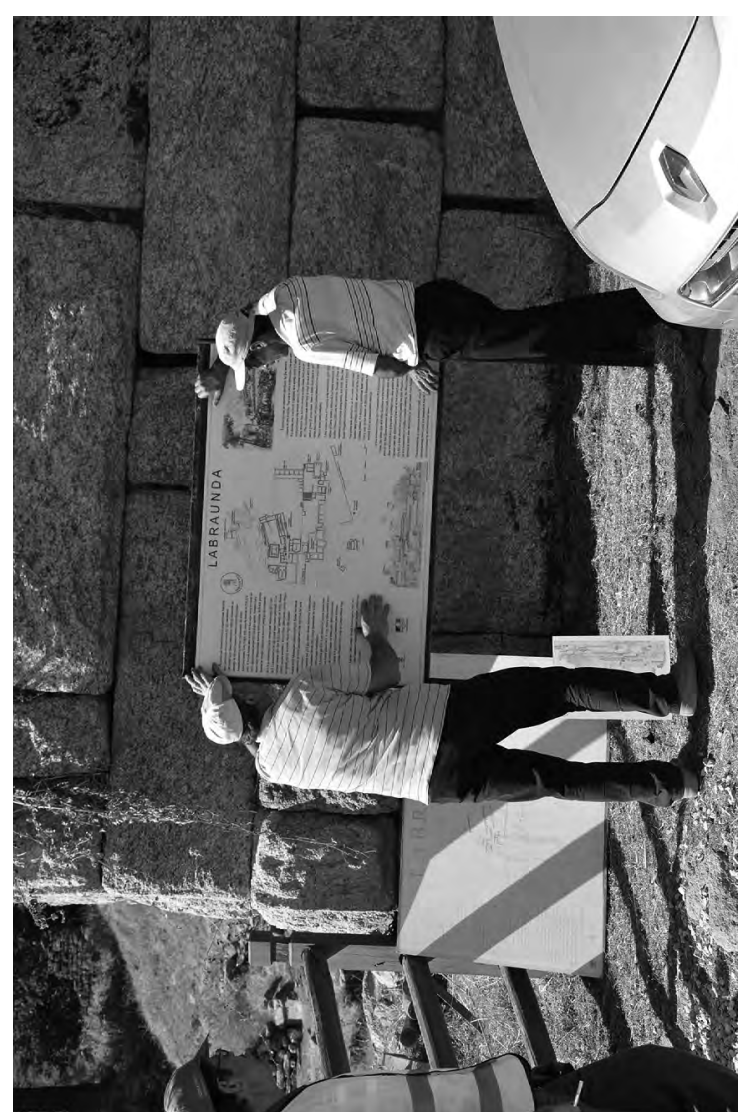

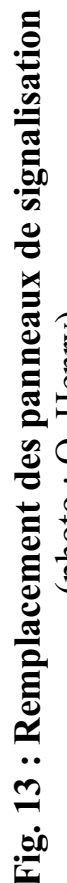

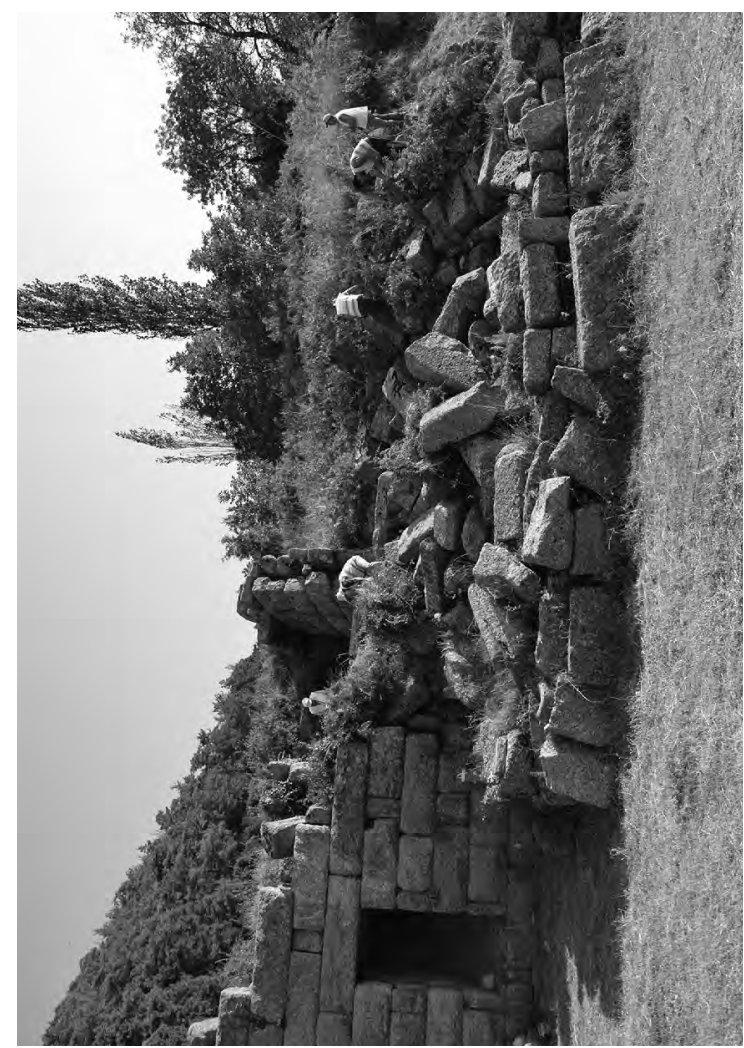



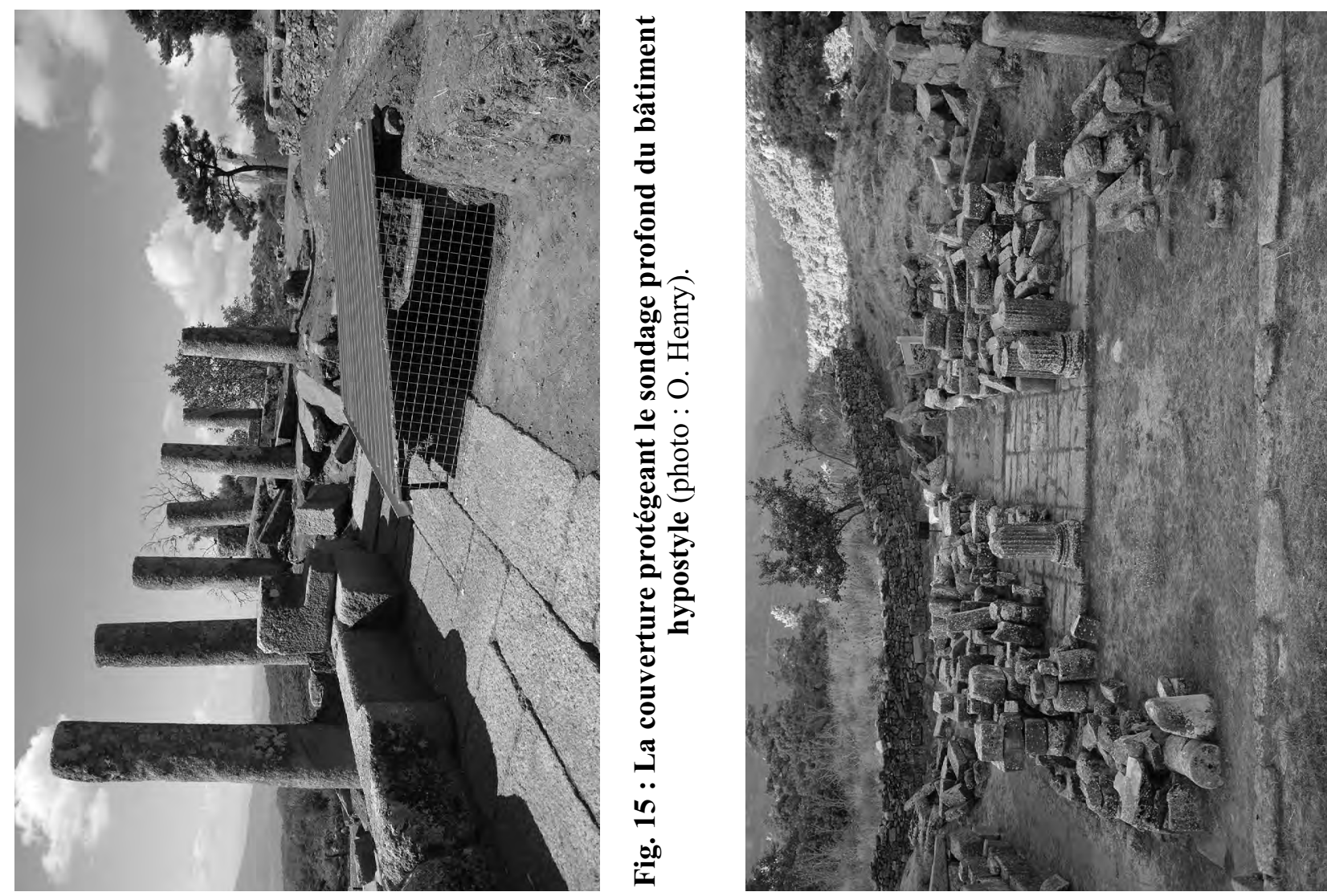

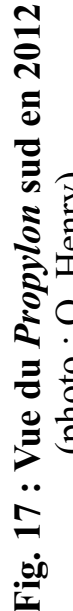
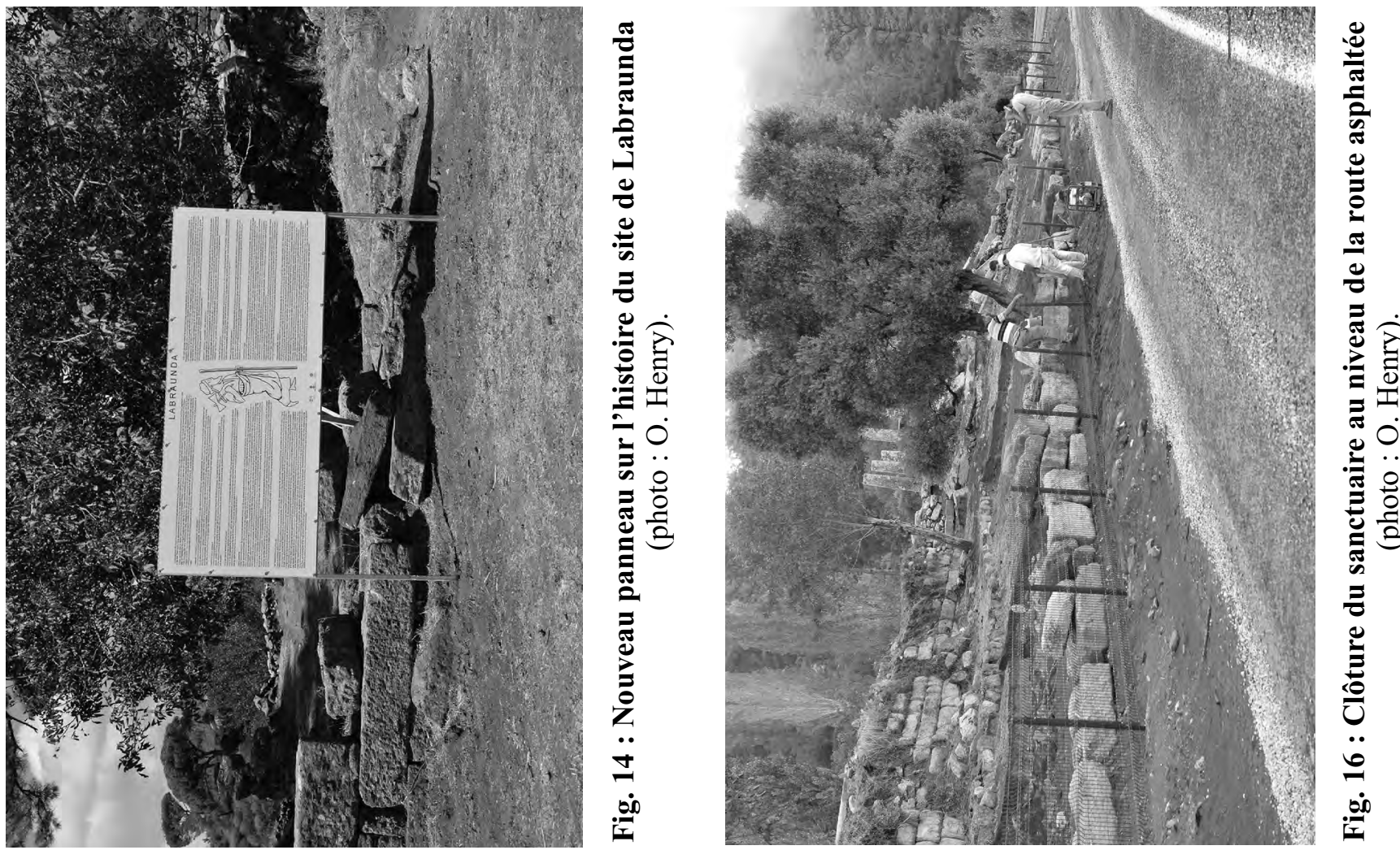


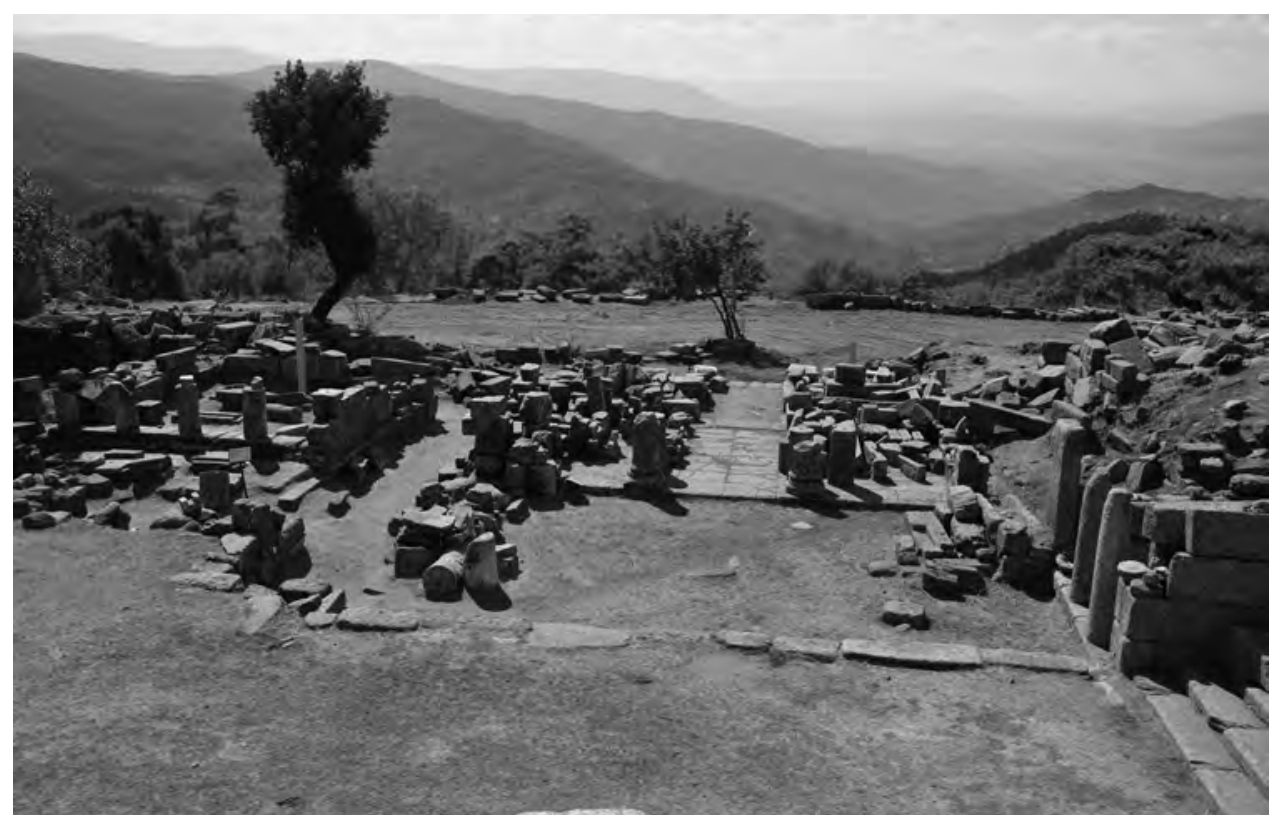

Fig. 18 : Vue du Propylon sud après l'enlèvement des remblais (photo : O. Henry).

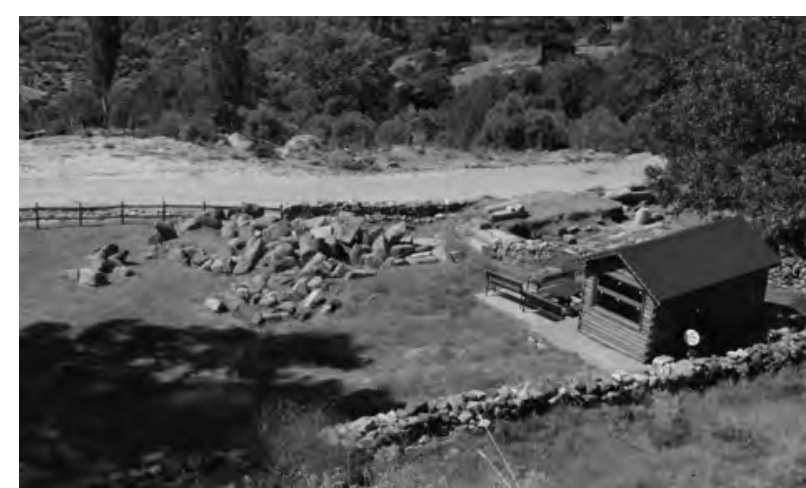

Fig. 19 : Vue de l'entrée du site en 2012 (photo: O. Henry).

(essentiellement des tuiles) (Fig. 18). Par contre on $\mathrm{y}$ a trouvé de très nombreux blocs de gneiss, provenant probablement des niveaux de destruction des structures dont sont issues ces terres. Les blocs ont été organisés de manière à ne pas gêner la circulation et placés les uns à côtés des autres le long de l'extrémité sud de la terrasse sud du site.

En outre, nous avons procédé à l'élimination de plusieurs murs de parcelles modernes, composés de petits blocs, qui subsistaient de l'exploitation ancienne des terrasses du sanctuaire en jardin.

Enfin, à l'entrée du site se trouvait un très large tas de blocs (Fig. 19), provenant du dégagement de la partie occidentale du mur de terrasse sud en 2004. Ces blocs ont été déménagés (Fig. 20) de l'entrée et alignés le long de la route asphaltée, derrière la barrière métallique construite cette année.

\section{Renforcement du point électrique}

L'équipe de cette année ayant été beaucoup plus importante qu'à l'accoutumée il a fallu parer aux besoins en matière de ressource électrique (ordinateur, imprimante, téléphone, etc.). Le site de Labraunda n'est effectivement pas desservie par une ligne électrique et nous avons dû improviser un nouveau système.

Nous avons donc fait appel à une société locale, spécialisée en énergie solaire, pour développer un point électrique sur le site. L'emplacement de ce point électrique est localisé au niveau de la maison du gardien (Fig. 21).

\section{Aménagement des dépôts de fouille}

Du fait du nombre important d'intervenants sur le site cette année, nous avons procédé au réaménagement des dépôts de fouille. Ainsi, le dépôt 1 qui servait également de salle de travail est dorénavant entièrement voué à recevoir le matériel céramique mis au jour lors des fouilles. A cet égard nous avons fait construire de nouvelles étagères métalliques qui recouvrent désormais l'intégralité des trois murs libres de la pièce (Fig. 22).

Le dépôt 2 qui servait autrefois de débarras pour les outils de fouille a été transformé en salle de travail. On y a fait parvenir l'électricité par câblage depuis la maison du gardien. Deux de ses murs ont été aménagés avec de grandes étagères en bois qui ont vocation à recevoir le matériel en cours de traitement (Fig. 23). 

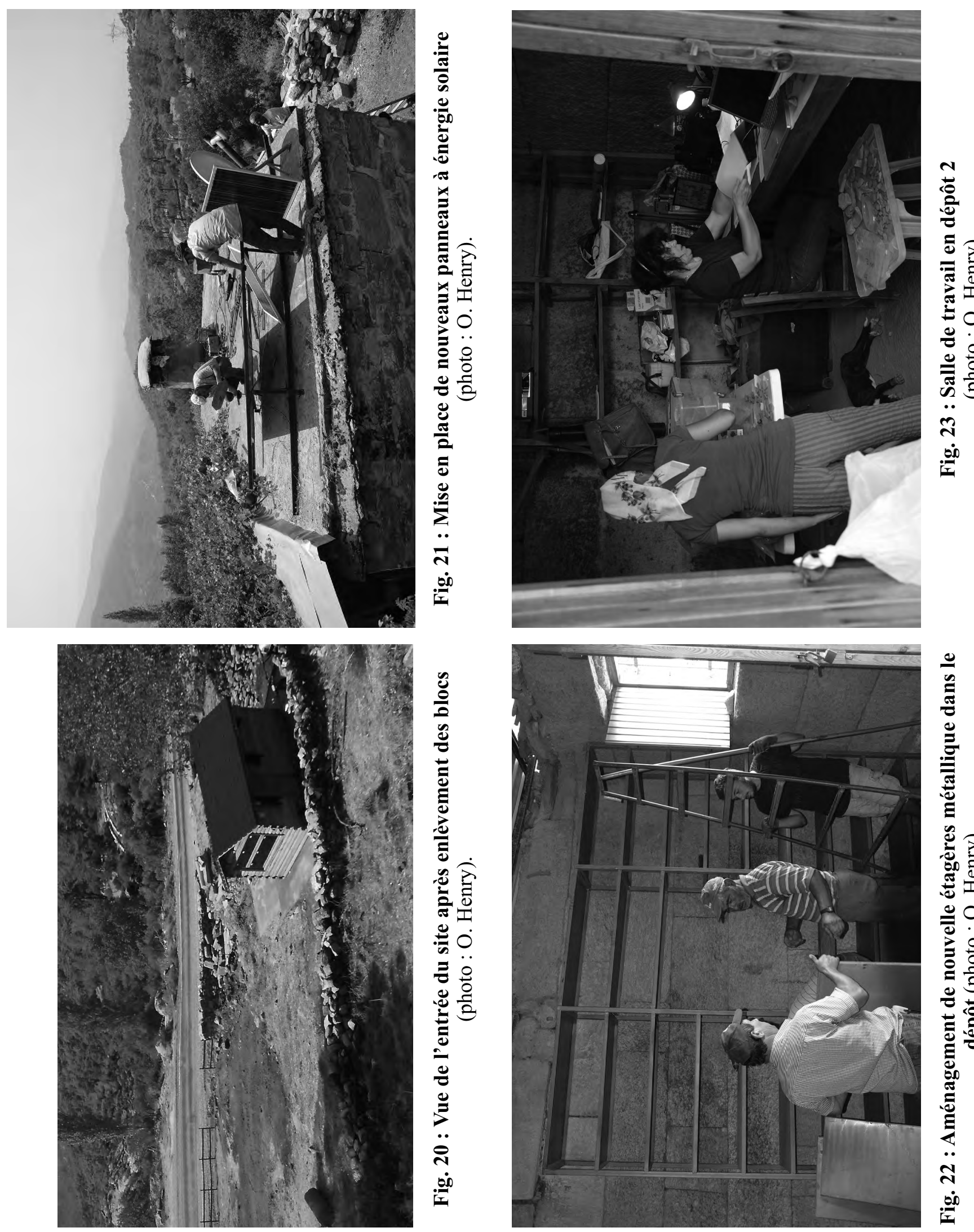


\section{DOCUMENTATION/ETUDES}

\subsection{Topographie/SIG}

(par P. Lebouteiller, IFEA-USR3131)

Le but de cette seconde campagne était de compléter le relevé topographique du lieu pour fabriquer un modèle en trois dimensions du terrain et recaler avec précision l'ensemble des monuments du site archéologique de Labraunda.

Pour effectuer cette campagne de relevés nous avons utilisé la combinaison de deux méthodes de travail : à savoir le positionnement satellitaire et le relevé topographique à l'aide d'une station totale. Le matériel utilisé pour le système de localisation mondial est un récepteur bi-fréquences de précision centimétrique (Fig. 24) en temps réel grâce aux corrections Omnistar'. Ce système utilise les satellites GPS (Américain) et GLONASS (Russe) pour augmenter la qualité de la réception et donc la précision des mesures. Les coordonnées sont corrigées en temps réel via les informations envoyées par le satellite privé Omnistar (ce qui évite d'avoir sur le terrain deux récepteur GPS et remplace le post traitement par du temps réel, permettant ainsi une vérification immédiate des données sur le terrain). Pour le traitement topographique classique nous avons utilisé la station totale Leica TC803 de l'IFEA (Fig. 25).

Sur le terrain la plupart des relevés pour la topographie s'est effectué par le GPS car la réception était satisfaisante compte tenu de l'orientation est/sudest du site. Les zones de forêts autour de l'acropole n'ont pas posé de problème grâce à la faible densité des arbres et à leur nature : des pins qui n'ont donc pas de feuillage, principal obstacle des ondes satellitaires. L'accès aux surfaces à relever en dehors du sanctuaire était assez difficile en raison de la présence de nombreux murets de pierres instables séparant chaque parcelle. Parfois le couvert végétal dense de type ronces ou petits arbustes ne permettait pas l'accès de certaines zones $(10 \%)$, tout comme la présence de nombreuses ruches à certains endroits.

Nous avons continué le travail de topographie commencé en 2012, associé à un relevé de chaque structure archéologique ou moderne avec l'attribution sur le terrain de classes d'objets. Cette classification permet d'entamer la constitution du S.I.G. (système d'information géographique) du site qui sera une base de donnée générale dans laquelle on pourra intégrer toute information géoréférencée du lieu. Chaque objet archéologique est associé à des méta-

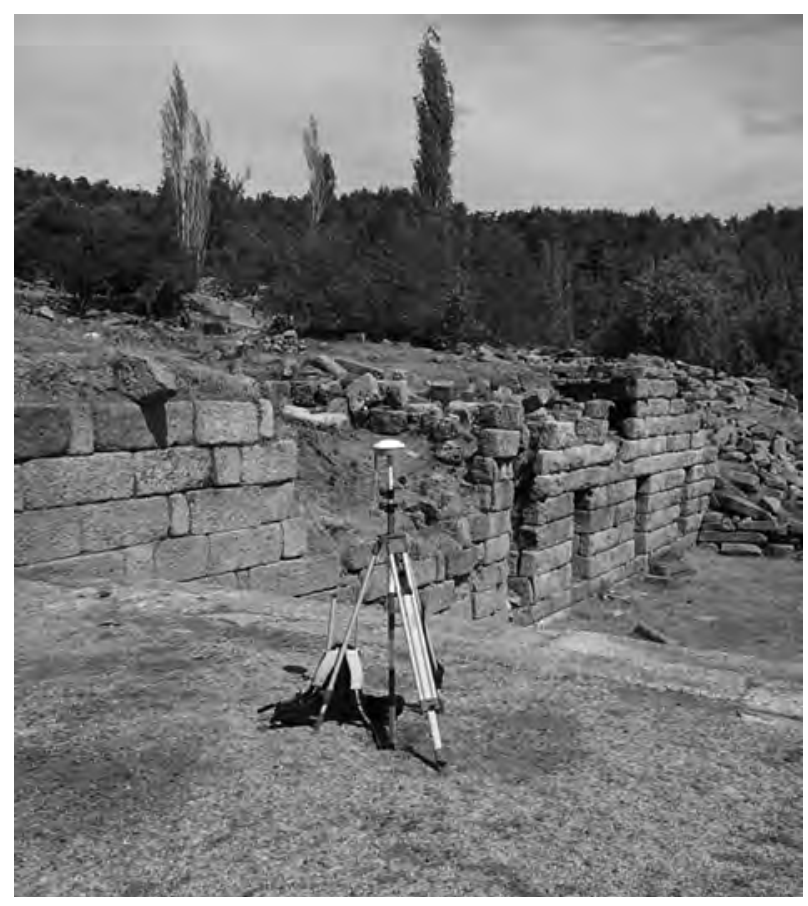

Fig. 24 : Récepteur GPS bi-fréquences en station (photo : P. Lebouteiller).

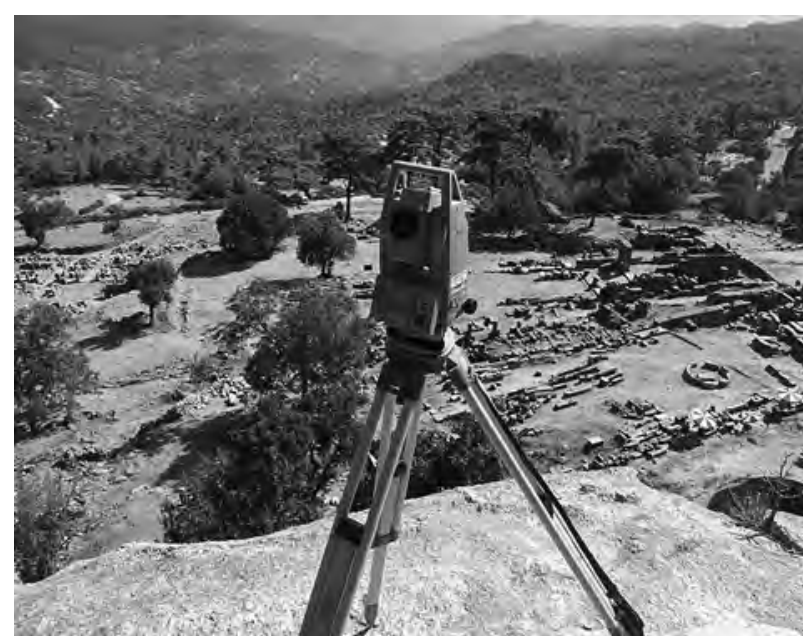

Fig. 25 : Station totale Leica TC803 de l'IFEA

(photo : P. Lebouteiller).

données sous forme de fiche avec nom, description, année, type, documentation associée ainsi qu'une localisation en coordonnées géographiques. Ce travail est rendu possible grâce à l'enregistreur de données couplé au GPS et permettant de documenter en temps réel sur le terrain, via une interface graphique, chaque objet ou bâtiment. 
Un travail de recalage des bâtiments principaux (déjà relevés au pierre à pierre) a été complété, ainsi qu'un positionnement des structures non relevées, qui a pour but de produire un plan topographique complet de Labraunda. Ce travail a été principalement effectué au GPS, la station totale permettant de compléter des zones localement difficiles d'accès par GPS.

Un relevé systématique des anciennes stations topographiques de 1979 (système local) a été effectué à l'aide de l'ingénieur suédois qui avait fait le plan original, pour pouvoir recaler et recalculer l'ensemble des points dans le nouveau système de coordonnées et d'altitudes.

Le traitement des données GPS pour la topographie pure ainsi que le traitement pour les données S.I.G. est assez lourd et les résultats ne sont actuellement que préliminaires. Nous présentons avec ce rapport un plan de synthèse de l'emprise des mesures effectuées sur le terrain (Fig. 26) ainsi qu'un plan topographique provisoire (Fig. 27).

Les mesures effectuées durant cette campagne (deux semaines en août pour le travail en station totale et deux semaines en septembre pour le GPS) permettront de réaliser un plan général du site archéologique sous forme de S.I.G. en incluant une grande partie de la nécropole, l'acropole, et les zones d'habitats autour du sanctuaire. Un modèle topographique $3 \mathrm{D}$ du site sera réalisé après traitement de toutes les données. Ce travail devra être complété dans les prochaines campagnes en fonction des résultats post-traitement notamment pour les zones intra-muros non relevées en détails, la zone de l'acropole après nettoyage, la nécropole (non relevée entièrement), la zone située au Nord-Est du site.

Un recalage systématique des monuments avec vectorisation des relevés pierre à pierre sera peut être souhaitable dans l'avenir si l'on veux tenir compte des bâtiments restaurés au cours des campagnes antérieures et avoir un plan mis à jour de l'état actuel du site.

\subsection{The exedra on the temple terrace (Fig. 28)}

(par F. Tobin, université d'Uppsala)

The temple terrace at Labraunda holds the archaeological remains of several free standing Hellenistic monuments. The largest of these is an exedra, placed at the eastern end of the North Stoa (also known as the stoa of Poleites). The exedra was excavated by Swedish archaeologists and finally re- assembled 5 July 1948 but has remained unpublished, with the exception of its inscriptions. During the 2013 campaign the exedra was cleaned of the dirt that had accumulated since the original excavation and subsequently photographed and drawn ${ }^{10}$.

The monument itself is semi-circular in shape, roughly 4 meters wide and 2 meters deep. It consists of a platform on which stands a curved back wall and a low bench. The exedra itself is made entirely of marble and stands on a rectangular base made of local gneiss. The northern edge of the base extends under the euthynteria of the North Stoa, suggesting that the construction of the stoa postdates the construction of the exedra (or at the very least the construction of the foundation of the exedra). This means that the stylobate of the stoa cannot date to the era of Maussollos.

There were originally a number of inscriptions on the monument. All of the inscriptions are today almost completely destroyed, but they were thankfully published by Jonas Crampa in 1972 when they were in better shape ${ }^{11}$. Crampa dated the inscriptions to the $3^{\text {rd }}$ century B.C. on account of the lettering.

Several bronze statues were originally placed on top of the back wall of the exedra. Although the statues themselves are long gone, the holes in the marble where they stood can still be seen. It is not possible to give a definite number of the original statues, but it has been estimated that there were at least nine of them ${ }^{12}$. Together with the cost of constructing the exedra itself, the project must have constituted a major economical commitment.

\subsection{Une nouvelle fontaine monumentale}

Suite à un important travail de nettoyage qui, cette année, a largement dépassé les limites du temenos, nous avons pu mettre au jour une structure jusqu'ici inconnue (Fig. 29). Pourtant située à proximité de la zone de travail, $110 \mathrm{~m}$ au Nord-Ouest du temple de Zeus, cette structure composée de larges blocs de gneiss offre un plan en $P i$ composé d'un mur orienté est-ouest de $7 \mathrm{~m}$ de long aux extrémités duquel on trouve deux murs de refend, probablement des antes, qui forment un retour de 1,60 m. Bien que le bâtiment soit très arasé il présente encore une élévation de plus de $1 \mathrm{~m}$. La technique de construction semble clairement hellénistique avec un arrangement du parement en carreau et boutisse. De nombreux blocs d'architecture sont encore visibles dans les murs de terrasses situées sous le bâtiment, on repère 


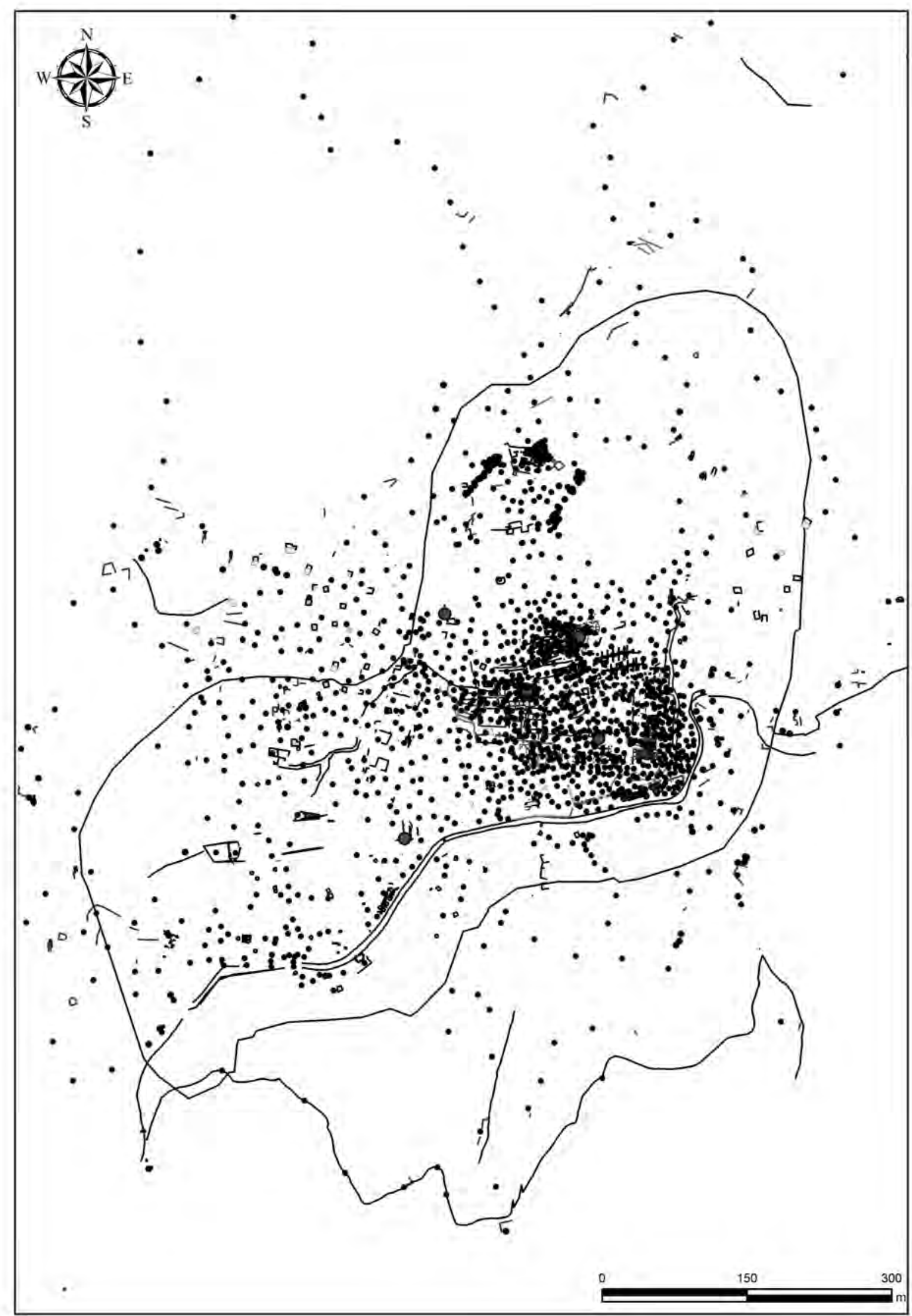

Fig. 26 : Plan de synthèse de l'emprise des mesures effectuées sur le terrain (cumulées 2012-2013) (P. Lebouteiller). 


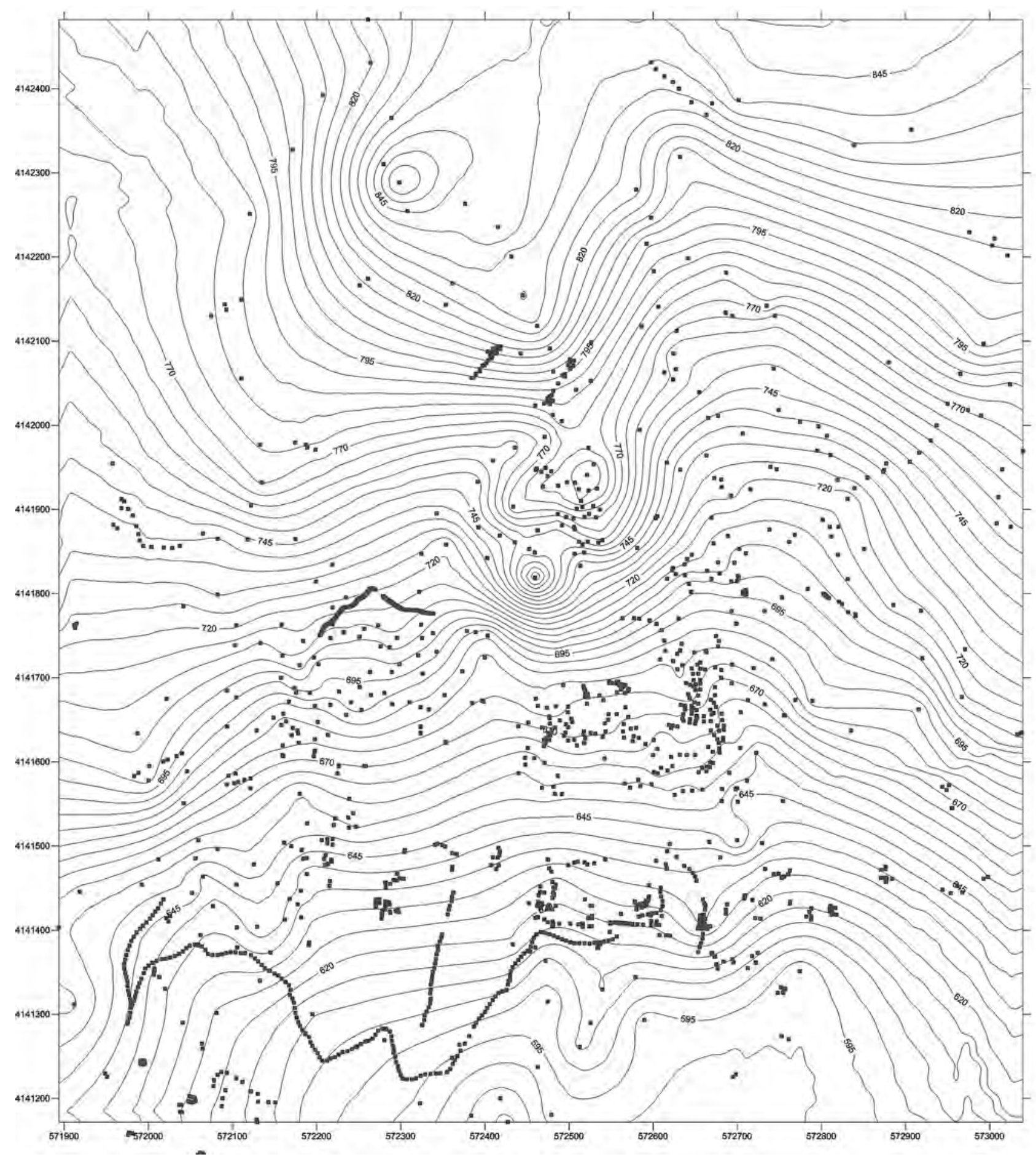

Fig. 27 : Plan topographique provisoire (P. Lebouteiller). 


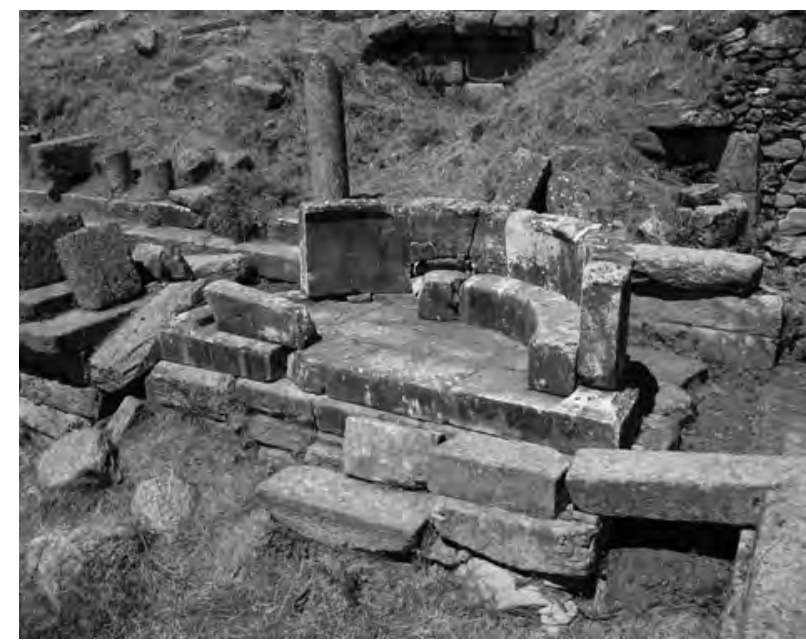

Fig. 28 : Etat actuel de l'Exèdre de la terrasse du temple (Photo : Fr. Tobin).

notamment deux futs de colonne ainsi que de très grandes architraves (Fig. 30).

La forme du bâtiment n'est pas sans rappeler le plan de la fontaine monumentale située au centre du temenos. La présence, en outre, quelques mètres en arrière du système bâti, d'une source d'eau aménagée semble plaider en faveur d'une telle identification.

La découverte de cette structure ayant été faite vers la fin de la mission de terrain, nous n'avons pu procéder à un relevé détaillé. Ce dernier sera réalisé au cours de la prochaine saison.

\subsection{Une nouvelle inscription monumentale}

(Fig. 31)

Une autre découverte fortuite a eu lieu cette année. Il s'agit cette fois d'une courte inscription gravée sur une face rocheuse, à 2,15 $\mathrm{m}$ au-dessus du sol. Le texte est simple, il présente un nom propre $\mathrm{AN} \triangle \mathrm{PONIK}$ D'après les témoignages des locaux, une première ligne de texte, comportant au moins un oméga était visible il y a encore quelques années. Malheureusement la partie haute de la face rocheuse portant l'inscription est aujourd'hui très érodée et il est impossible d'y lire quoique ce soit. On note cependant la présence, plus haut, d'une petite cavité qui pourrait correspondre a un trou de poutre (mais il semble bien étroit).

La présence de cette inscription, à $320 \mathrm{~m}$ à l'Ouest du temple de Zeus et $120 \mathrm{~m}$ au Nord-Ouest de la maison de fouille étonne. En effet, même si le nombre d'inscriptions découvertes sur le site est très important, depuis le début des fouilles, aucune n'est gravée sur le rocher même. La forme dative du nom semble indiquer une possession et il est possible que ce nom soit celui du propriétaire des terres

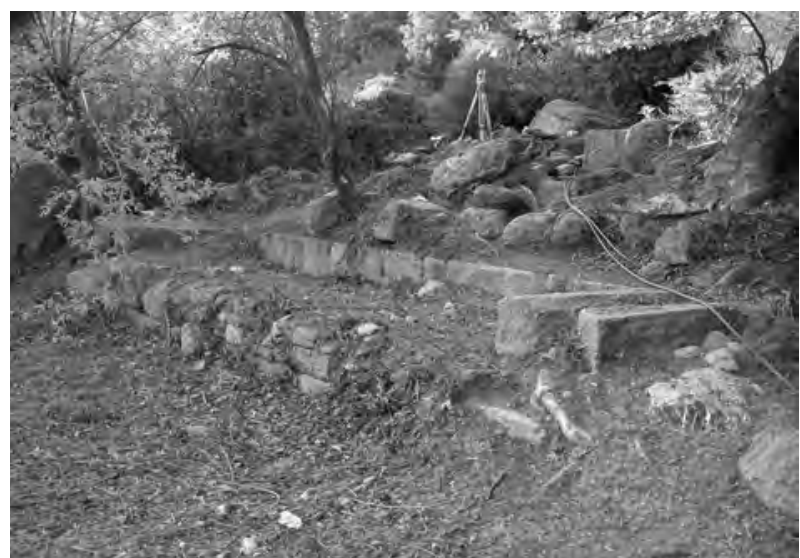

Fig. 29 : La fontaine monumentale après nettoyage (photo : O. Henry).

alentours. Ces dernières offrent de très nombreux affleurement rocheux qui portent presque tous des traces d'extraction de pierre. S'agit-t-il d'une zone de carrière privée dont le propriétaire a voulu marquer la possession ? On précisera que la taille de l'inscription est impressionnante puisqu'elle mesure 2,18 $\mathrm{m}$ de long avec des lettres de 17 à $20 \mathrm{~cm}$ de haut (l'omicron est plus petit, $13 \mathrm{~cm}$ ). La forme des lettres (alpha à haste brisée, rho effilé et petite taille de l'omicron) semble indiquer une date autour de la fin de la période hellénistique.

\subsection{Les recherches géophysiques}

Cette année une campagne de recherche géophysique a été menée dans trois secteurs du sanctuaire (Fig. 32). Le premier concerne l'angle nord-est du temenos, le second la partie sud-ouest du sanctuaire, dans l'angle formé à l'Ouest par le long mur de terrasse sud, le dernier est situé au Nord et au contact du bâtiment hypostyle.

Dans le premier secteur nous avons utilisé les méthodes électriques et magnétiques tandis que pour les deux autres secteurs seule la méthode électrique a été mise en place.

\section{Zone 1 (Fig. 33-34)}

Le choix de cette zone a été déterminé par le fait qu'il s'agit d'un secteur situé à l'intérieur du temenos qui n'a jamais fait l'objet d'aucune recherche. La zone est pourtant très large et ne présente aucune trace de vestige en surface. L'analyse électrique a permis de couvrir une zone de $351 \mathrm{~m}^{2}$, à l'aide de 14 profils. La résistivité du sous-sol a été analysée sur une profondeur comprise entre 0,5 et $4,38 \mathrm{~m}$. 


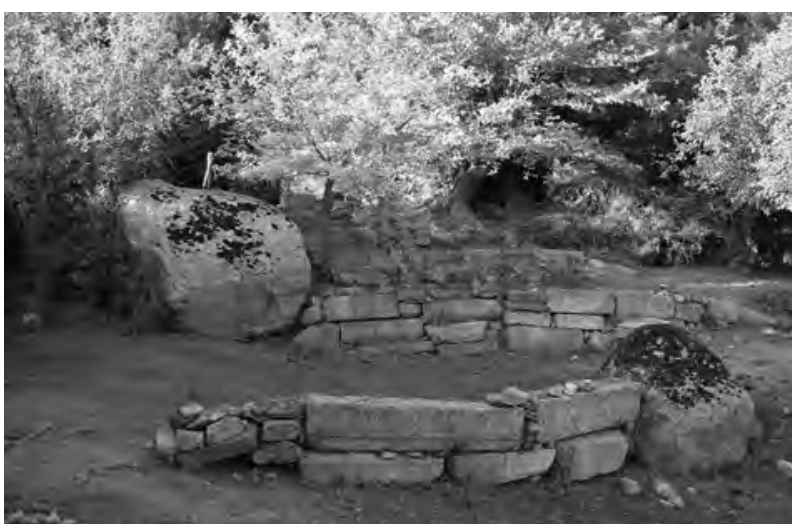

Fig. 30 : Blocs architecturaux de la fontaine monumentale dans les murs de terrasse alentours (photo : O. Henry).

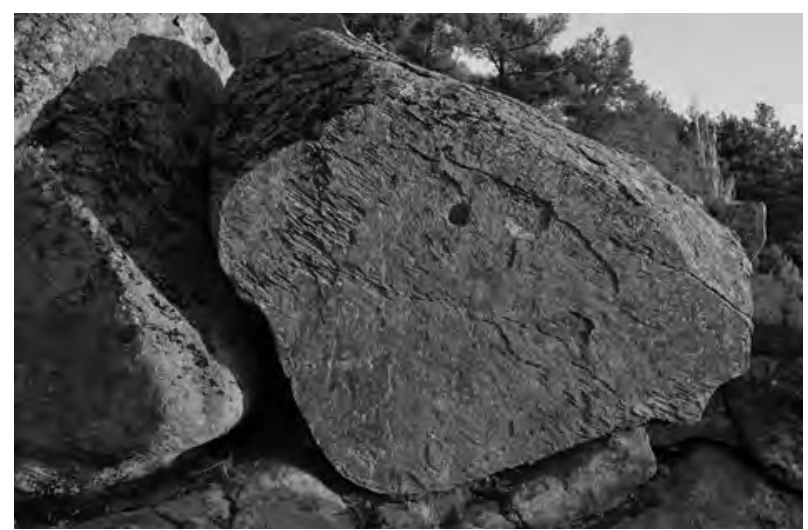

Fig. 31 : L'inscription rupestre (photo : O. Henry).

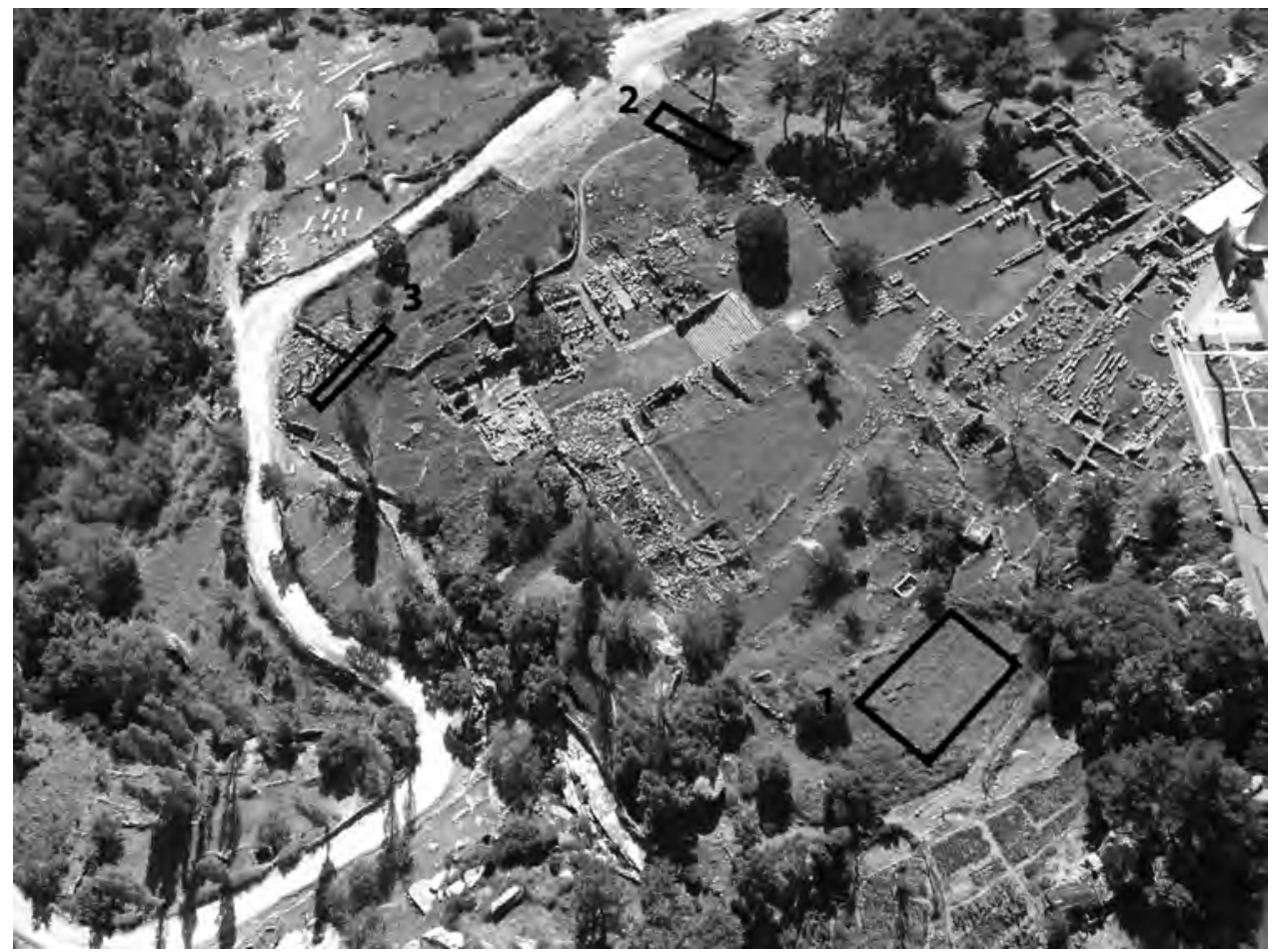

Fig. 32 : Localisation des trois zones balayées par les prospections géophysiques (photo : O. Henry).

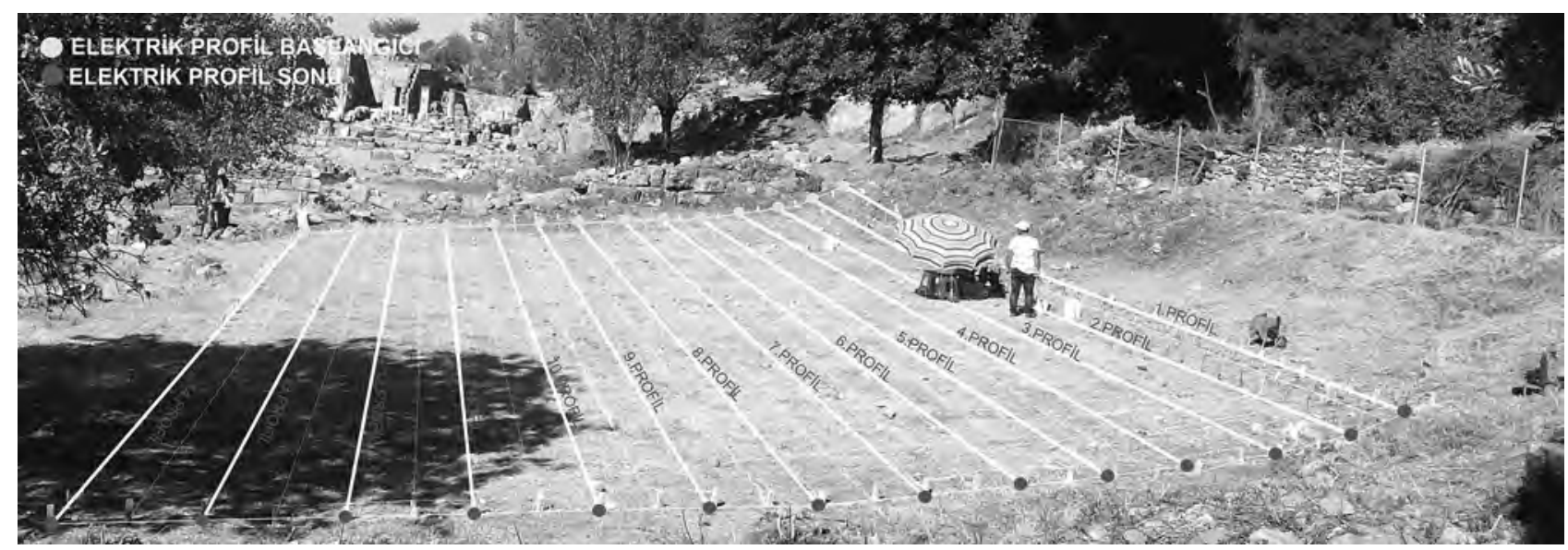

Fig. 33 : Mise en place du système d'analyse en zone 1 (C. Karavul). 

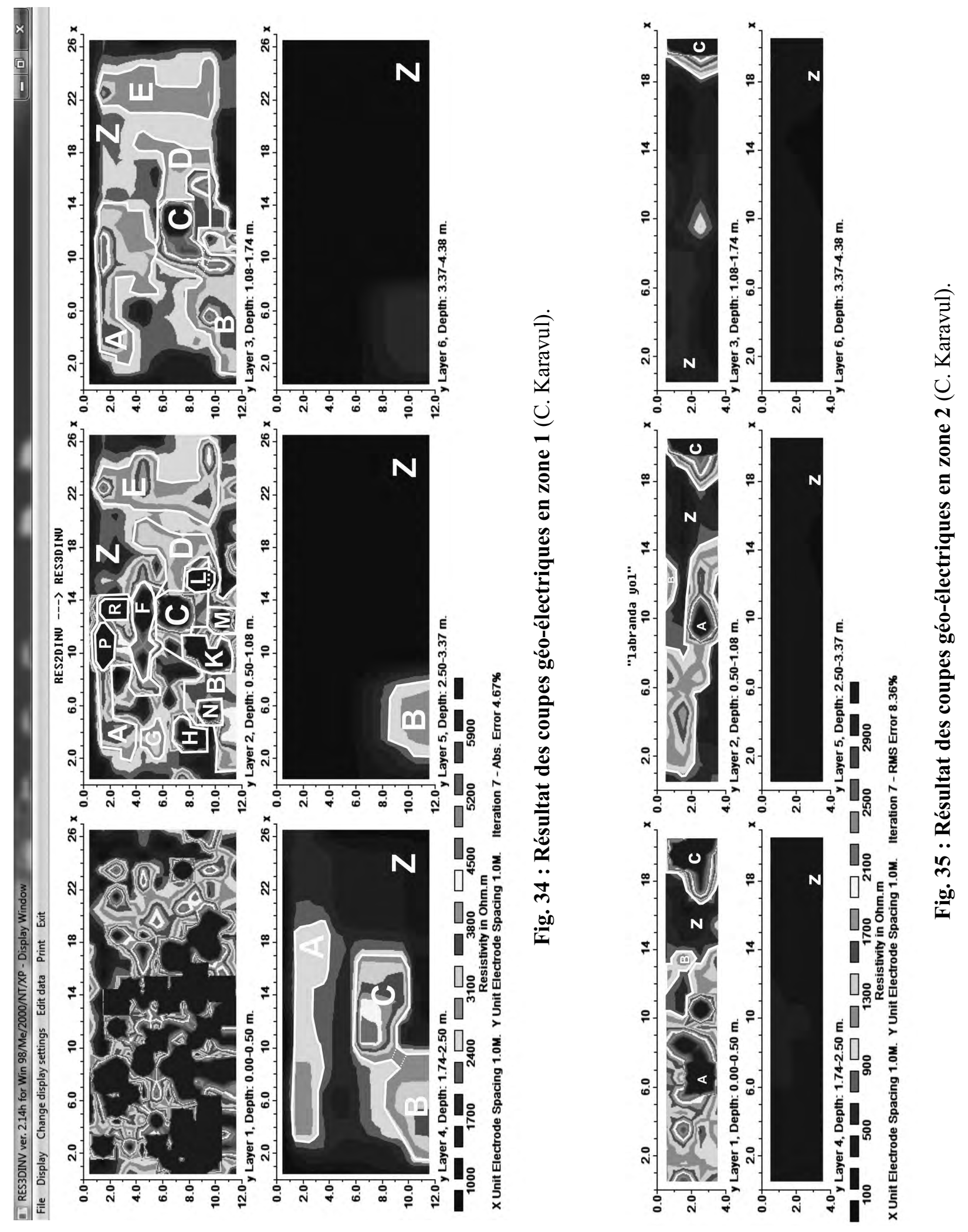


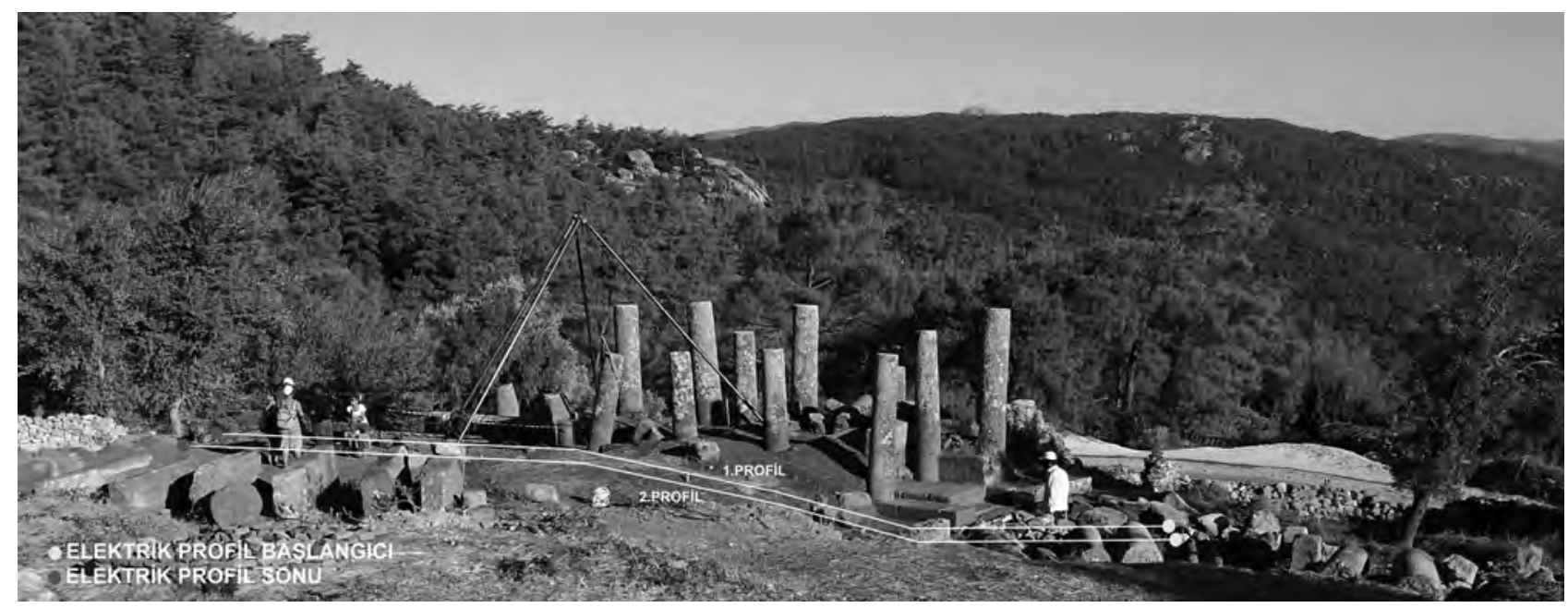

Fig. 36 : Mise en place du système d'analyse en zone 3 (C. Karavul).

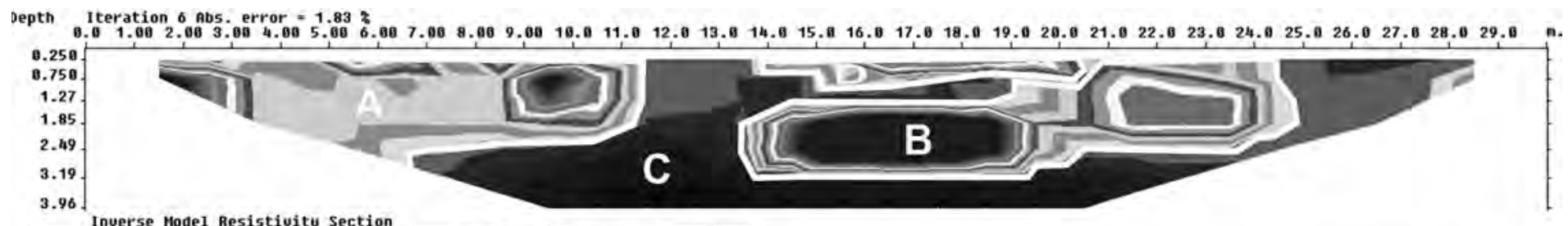

Inverse Model Resistivity Section

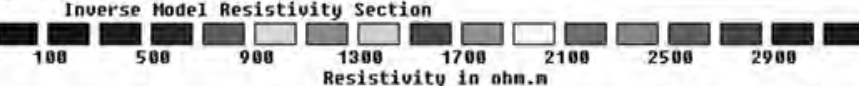

Unit electrode spacing $1.06 \mathrm{n}$.

Fig. 37 : Résultat des coupes géo-électriques en zone 3 (C. Karavul).

Dans la carte de représentation, la zone $(Z)$, représente l'unité géologique des sols alluviaux. Les éléments notés A, B, C, D, E, G, H, L et M sont des zones dont les valeurs de résistivité sont beaucoup plus élevés que l'unité géologique et correspondent à des éléments de gneiss.

L'interprétation des résultats semble indiquer la présence d'une structure bâtie formée par les anomalies $\mathrm{A}, \mathrm{B}, \mathrm{C}, \mathrm{D}$, et $\mathrm{E}$, tandis que les zones $\mathrm{G}, \mathrm{H}$ et $\mathrm{M}$ pourraient correspondre à des éléments annexes, probablement liés à des niveaux de destruction. Le bâti semble très bien conservé entre $1 \mathrm{~m}$ et $2,50 \mathrm{~m}$ de profondeur. Il paraît être composé de deux chambres (A et B) reliées entre elles par un couloir (C). L'ensemble présente des niveaux de résistivité permettant de supposer qu'il s'agit de pièces creuses dont la couverture est encore conservée. On note également la présence d'eau sur toute la surface analysée. Il est possible que cette eau provienne de la source située au Nord-Ouest de la zone étudiée, sans qu'elle ait de rapport direct avec la structure découverte. Il est aussi probable que les structures soient directement liées à une exploitation de l'eau (bains, citernes, etc.).

\section{Zone 2 (Fig. 35)}

Nous avons utilisé 5 profils de $21 \mathrm{~m}$ de long dans ce secteur, permettant de couvrir une superficie de $84 \mathrm{~m}^{2}$. Le but de cette prospection était de déterminer s'il existait une structure d'accès dans l'angle sud-ouest du temenos qui permettait d'accéder à la première terrasse du site depuis la voie antique. Les coupes qui résultent de l'analyse indiquent la présence de blocs de gneiss en grande quantité (A) mais sans schéma d'organisation clair. Il semble donc que nous soyons en présence de niveaux affleurant de destruction.

\section{Zone 3 (Fig. 36-37)}

$\mathrm{Du}$ fait de l'étroitesse de la zone accessible, nous n'avons pu placé dans ce secteur qu'une paire de profils. Ces derniers visaient à déterminer la présence ou non d'une structure connexe au bâtiment hypostyle.

L'analyse présente un certain nombre d'anomalies (A et B) importantes et essentiellement composées de blocs de gneiss. Il est malheureusement impossible de déterminer s'il s'agit d'un bâti ou d'un niveau de destruction. 


\subsection{Marble Trade Project}

(par A. Freccero, restauratrice indépendante)

What is the provenance of the marble used at Labraunda? According to tradition, the marble was supplied by quarries at Sodradag at the feet of which Mylasa, the ancient capital of Caria, was laid out. The fact that antique quarries have been identified at the southern slopes of Mount Sodra contributes to the reasonable hypothesis that Sodra would be the place of provenance. On the other hand, there are other mountains around Milas, and white marble was quarried at many known caves in the region. Another origin can therefore not be excluded. The plan of the present study is to try to establish the origin of the Labraunda marbles and thereby shedding some light on the transport roads and marble trade in the area.

There are at least three kinds of marble at the Sanctuary of Labraunda (Fig. 38). According to ancient writers, such as Strabo, Mylasa was known for its many buildings of white marble, and he suggests that such marble might have been used at Labraunda too ${ }^{13}$. Could three different kinds of marble have been quarried at Sodradağ? Yes, it is possible, because diverse quarries in a mountain may provide different kinds of stones. Another possibility is that some blocks were brought from Sodra and other pieces from yet unknown caves, and that trading routs are liked to periods in time. There is also the option that one type of marble was preferred for sculpture and finely cut inscriptions and architectonic elements while another quality was used for columns, bases and anta blocks, and these qualities may have different origins. I assume that the Karian kings, in order to impress the people and demonstrate their power would choose what was considered the very best at the time, rather than choosing the product nearest available only because the transport was easier and cheaper. Was Mylasa marble known as the best, was it considered as superior to e.g. the famous marble from Herakleia?

The present study, which began in September 2013 , evolved from the analyses of a few pieces of marble as part of the conservation project at the site. Results from this initial, simple study will be briefly described below because the results led to the de-

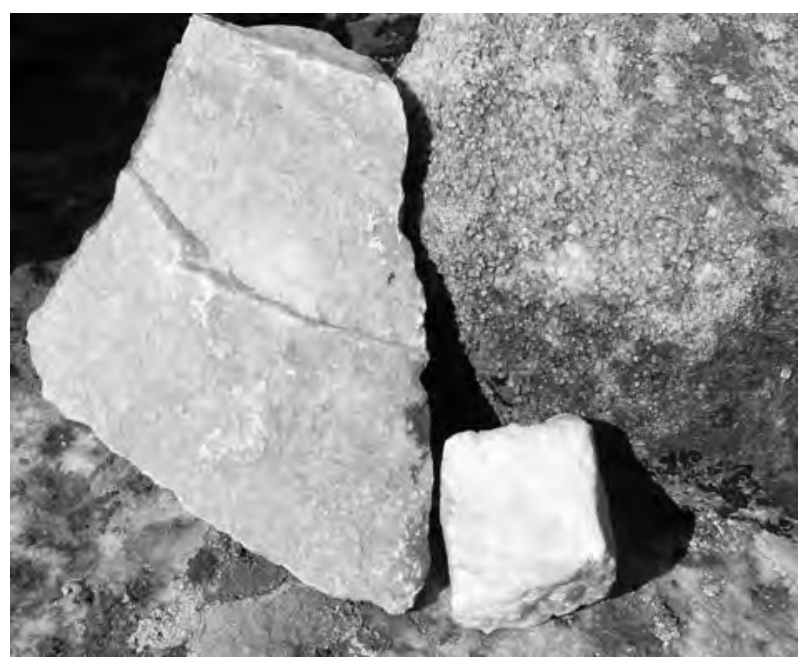

Fig. 38 : The three different kind of marbles at Labraunda (photo : A. Freccero).

velopment of a plan for a research project, for which I received funding this year ${ }^{14}$.

Ocular observations during surveying and conservation in 2011-2012 indicated there were at least three kinds of marble at the site. Most characteristic was a large-grained white marble which often had veins of large calcite crystals. The marble used was identified at columns and architraves of Hekatomnid buildings. The second distinctive type was a finegrained white marble, used for the Corinthian capitals of the so called North Stoa of the Roman period. The third marble type was pale grey with fine grains, identified at blocks that were not noted in the conservation plan. There are also some less distinct marbles which are e.g. white with grey veins or white with medium sized grains. These may be variations of those mentioned above or they are additional types. In order to see if there was any link between Sodra and Labraunda, four marble samples were sent for analyses to CNR/ICVBC in Florence in 2011'5. Two of these were obtained at Labraunda, one from quarries at Sodra and an additional white piece of marble obtained at a modern quarry close to Stratonikeia. All samples were fallen pieces on the ground, and therefore not indicative of any period; the only reason was to understand if there was any connection between the marbles.

13) Strabo 14.658.

14) My gratitude goes to the Swedish Academy of Letters, History and Antiquities, and to Helge Ax:son Johnsons stiftelse, for financing this research. My sincere thanks go to Olivier Henry who introduced me to professionals of importance for this project.

15) Consiglio Nazionale delle Ricerche/Istituto per la Conservazione e Valorizazione dei Beni Culturali. 
The results of the investigation are briefly presented below.

Sample
Labraunda bianco (white)
Labraunda grigio (grey)
Sodra (white)
Stratonikeia (white)

Mineralogical composition Calcite, traces of Dolomite medium/large grains

Dolomite, calcite, fine grains Dolomite, calcite, fine grains Quartz (not marble)

According to analyses the fine-grained grey marble at Labraunda and the sample taken at Sodra were very similar, but the characteristic large-grained white marble at Labraunda, almost exclusively calcite, was different.

Next year the study was slightly expanded and five samples were obtained from datable objects. Two samples were obtained at the architraves with dedications of Maussollos and Idrieus (A3, C42), representing the Hekatomnid period. Two samples were removed from two of the Corinthian capitals (CorCap1, CorCap2), representing the Roman period. A fifth sample was removed from an un-fluted column (LabCol), and probably of the Roman period too. A sixth sample (MaTo) was removed at the marble tomb situated near the village of Kargicak. The tomb was sampled when a few cleaning tests were made with the objective of finding a method of removing the red matter that covers the walls and reduce the effect of graffiti. The results are briefly presented below.

$\begin{array}{ll}\text { Sample } & \text { Mineralogical composition } \\ \text { A3 } & \text { pure calcite marble, medium/large grains } \\ \text { C42 } & \text { pure calcite marble, medium/large grains } \\ \text { CorCap1 } & \text { calcite marble, fine grains } \\ \text { CorCap2 } & \text { calcite marble, fine grains } \\ \text { LabCol } & \text { alcite marble, medium large grains } \\ \text { MaTo } & \text { calcite, Dolomite, very fine grains }\end{array}$

The two samples from the architraves were not identical but had similar characteristics. The Corinthian capitals were of the same kind, representing a different type of marble, and the column was, in spite of similarities to the architraves, different from these. Of quite a different composition was the extremely fined-grained greyish marble from the tomb, considered to be a breccia rather than marble.

At this point, it was possible to distinguish three preliminary groups. The large-grained white marble constitutes one group (Labraunda bianco, C3, C42, and LabCol). The marbles in this group are similar but nor identical. One fine-grained group includes one grey and one white piece of stone (Labraunda grigio and Sodra). The two capitals' marble belongs to the third group.

But what is the provenance of the marbles, and in particular the large-grained white type? My study has just begun. I have been reading articles on recent research on Greek and Turkish marbles where traditional and recently developed analytical methods were used ${ }^{16}$, made a strategy for sampling and documentation, and taken contact with persons that may give suggestions and advice. During a week in September I visited antique quarries and started sampling. Since this is just the beginning, there is nothing more to say at the moment but, hopefully, there will be a lot to report next year.

So what is the reason for doing this study? It began as a question on where the marbles came from. Then I found contradictory information and was caught; I really had to understand what was correct and what was hearsay or repetition. I think it is important to have evidence and facts and to present them. Commerce in the Roman era is well known, but how was trade in Caria developed before the Romans came? Identification of the marble used for the early buildings provide an idea on the costs the rulers were willing to pay for the monumental buildings at this important sanctuary, which in turn offers an idea of the site - and of the kings. This study hopefully will lead to a perception about quarrying, marble trade, and the trading routes along which the Labraunda marbles found its way in the Hekatomnid period until the Byzantine time.

\subsection{Le sanctuaire de Kybele (Fig. 39)}

En 2012, nous avions mis au jour un grand nombre de structures associées à un petit sanctuaire surplombant la terrasse du temple de Labraunda. Parmi celles-ci, la plus surprenante était la présence d'un large mur associé à du matériel daté, par des collègues de Milet et Latmos, de la fin de la période Chalcolithique ou du tout début de la période du Bronze $^{17}$. La saison 2013 s'est concentrée sur la documentation des structures (relevé pierre à pierre) et de l'ensemble du matériel mis au jour. Ce dernier semble couvrir une très large chronologie qui s'étend jusqu'à la période hellénistique. On note un 'vide' surprenant entre le début de l'âge du Bronze et la

16) Mineralogical and petrographic investigations, chemical and isotopical analyses, chemical analyses of inclusion fluids and extractable salts.

17) Voir Henry et al. $2013: 298-300$. 


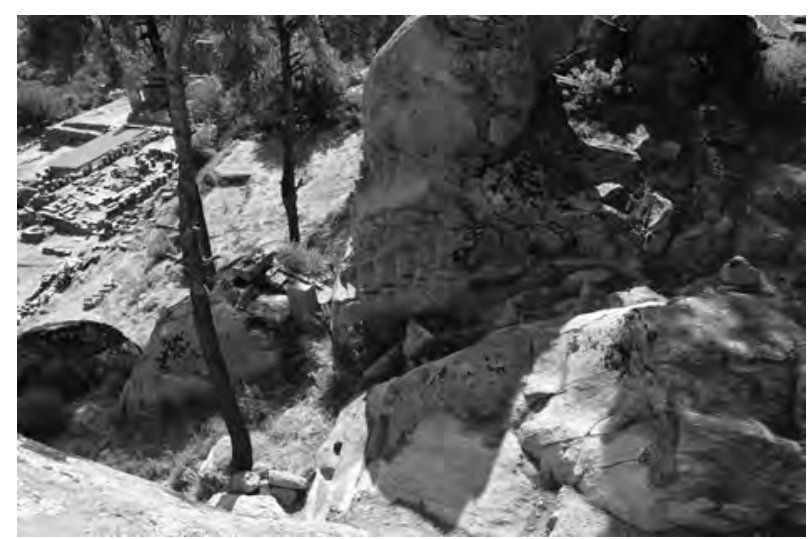

Fig. 39 : Le sanctuaire de Kybele (photo : O. Henry).

période archaïque. La présence d'un matériel aussi ancien, associé à du bâti semble indiquer que ce petit sanctuaire (dédié à la déesse Kybele ?) représente une partie des racines du sanctuaire de Zeus Labraundos.

\subsection{Les céramiques de Labraunda}

(par V. Lungu, Institute of South-Eastern

European Studies, Académie Roumaine)

En 2013 nous avons entamé une large étude des céramiques de Labraunda. Le but de cette entreprise est de procéder à une approche globale du matériel du site, qui permettrait de définir un faciès global de la céramique carienne de la période classique à la période byzantine. Le statut même du sanctuaire permet en effet d'approcher un matériel très varié et provenant probablement des quatre coins de la région, importé par les pèlerins au cours de leur visite du sanctuaire.

Cette année nous avons étudié plusieurs centaines de tessons. Parmi ceux-ci, on a eu la possibilité d'identifier et dessiner plusieurs dizaines de formes. A côté de divers centres d'importation, identifiés en étudiant les caractéristiques communes de la pâte et le traitement de surface, nous avons repéré, pour quelques-uns de ces vases, des caractéristiques morphologiques plutôt attribuables à des centres locorégionaux. Nous avons porté une attention particulière au répertoire des formes de chacun des groupes distingués.

Les principaux domaines de la recherche de 2013 à Labraunda ont été les suivants :

\section{Etudes céramiques de contextes funéraires (incomplète)}

LAB.10. Well NECROP : amphores de transport: 21 fragments d'origine diverse ; vernis noir : 4 fragments; vases à tourner : 5 fragments (cruche, oinochoe); vase à servir : 31 fragments (bol, bolsal, coupe, coupelle); vases de cuisine : 74 fragments ; vases de stockage : 3 fragments pythos; vases utilitaires : 6 lekanis ; 1 situle ; 1 amphore de table ; 2 stamnos ; 2 exemplaires fragmentaires de figurine drapée ; 1 fragment de lampe ; 162 fragments indéterminés. TOTAL : 313 objets.

LAB.10.T17 : 4 fragments d'amphores de transport d'origines diverses ; vases à tourner : 1 fragments (cruche) ; 25 fragments de vase à servir (bol) ; 3 fragments de vases de cuisine ; 6 fragments de vases utilitaires (unguentaria) ; 5 tuiles ; 1 fragment de verre ; 121 fragments indéterminés. TOTAL : 166 objets.

LAB.10.T22: 2 fragments de vases de stockage (pithos) ; 5 tuiles ; 29 fragments indéterminés. TOTAL : 36 objets.

LAB.10.T81 : 1 fragment d'amphore de transport ; 1 fragment de vernis noir ; 1 fragment de vase à tourner (cruche) ; 3 fragments de vase à servir (bol, coupelle); 12 fragments indéterminés. TOTAL : 18 objets.

LAB.10T82: 6 fragments de vase à servir (bol); 1 fragment de vase utilitaire ; 55 fragments indéterminés. TOTAL : 62 objets.

LAB.10.T84 : 1 fragment de vernis noir (bolsal); 2 fragments de vases à tourner (cruche); 1 fragment de vase à servir (bol) ; 2 fragments de vases de cuisine ; 7 fragments de vases utilitaires (couvercle, lekanis, lekythos) ; 1 fragment de vase de stockage ; 2 fragments de tuiles; 12 fragments indéterminés. TOTAL : 28 objets.

LAB.10.T85: 2 fragments de vases à tourner (cruche) ; 2 fragments de vase à servir (bol) ; 1 fragment indéterminé. TOTAL : 5 objets.

LAB.10.T89 : 4 fragment de vernis noir (bolsal; skyphos) ; 2 fragments de vases à tourner (cruche); 3 fragments de vase à servir (bol); 1 fragment de verre ; 27 fragments indéterminés. TOTAL : $37 \mathrm{ob}-$ jets.

LAB.10.T90 : 1 fragment de céramique fine à engobe rouge ; 3 fragments d'amphore de transport ; 10 fragments de vases à tourner (cruche); 8 fragments de vase à servir (bol, fruit-stand, écuelle) ; 17 
fragments de vases de cuisine ; 43 fragments indéterminés. TOTAL : 82 objets.

LAB.10.T90 above lid : 1 fragments de vases à tourner (cruche); 1 fragment de vase à servir (bol) ; 2 fragments de vases de cuisine ; 7 fragments de vases utilitaires (lekanis) ; 1 fragment de vase stockage ; 39 fragments indéterminés. TOTAL : 51 objets.

LAB.10.T92 : 1 fragment de vase à tourner (cruche) ; 9 fragments indéterminés. TOTAL : 10 objets.

LAB.10.T93 : 1 fragment d'amphore de transport ; 1 fragment de vase à servir (bol) ; 1 clou en fer ; 2 fragments indéterminés. TOTAL : 5 objets.

Nous avons aussi travaillé sur 87 vases différents, sélectionnés de contextes divers (tombes et 'well necropolis').

\section{Etude et dessin du matériel céramique de LAB.13.BTC}

Nous avons documenté 80 nouveaux fragments céramiques de ce contexte (lié à l'aménagement du bâtiment en $P i$ de la tombe monumentale, voir infra section 4.2), en procédant en même temps à la description de la pâte. Les fragments ont été sélectionnés à partir de plusieurs centaines d'échantillons. Ils représentent des fragments reconnaissables (lèvres, pieds, fragments de panse, anses) de plusieurs formes différentes. Parmi celle-ci, on note surtout certaines pièces de vaisselle de table (bols à parois caréné, assiette à lèvre déversée, skyphos à anse en accolade, bol convexe, bol jatte, etc.) et des amphores de transport d'origines différentes, notamment de Rhodes, Cos et Knidos. On note particulièrement le nombre réduit de céramique décorée (un seul fragment d'un bol à décor en relief) et également de la céramique de cuisine. Les vases de stockage apparaissent assez souvent, tout comme les tuiles. La chronologie générale de la fouille de 2013 dans ce secteur s'inscrit entre les $3^{\text {e }}$ et $2^{\mathrm{e}}$ s. av. J.-C.

\section{Etablissement du répertoire céramique du site.}

En l'état actuel, et préliminaire, de l'étude, une première classification peut être établie :

Amphore de transport : 1 Milet ; 2 Chios ; 2 Rhodes ; 2 Cos (?) ; 2 indéterminées (possible locorégionales pâte brune rougeâtre, granuleuse)

Amphore de table : 4 exemplaires, divisés en 3 variantes typologiques

Basin : 7 exemplaires

Bol à décor en relief (ou Mégarien) : 1 exemplaire
Bol à lèvre incurvée : 11 exemplaires, divisés en 5 variantes typologiques

Bolsal attique : 1 exemplaire

Bolsal non-attique (probablement loco-régional ?) :

8 exemplaires

Coupe achéménide : 1 exemplaire

Coupelle : 7 exemplaires

Couvercle : 2 exemplaires

Cruche : 14 exemplaires, plusieurs variantes typologiques

Ecuelle : 3 exemplaires

Figurine : 1 exemplaire Milet)

Fruit-stand : 1 exemplaire (probablement, de

Lampe : 2 exemplaires

Lekanis : 9 exemplaires, divisés en plusieurs variantes typologiques

Oinochoe : 3 exemplaires

Olpe : 3 exemplaires

Phiale : 1 exemplaire

Pythos: 1 exemplaire

Lopas à panse biconique : 2 exemplaires

Unguentaria : 6 exemplaires

TOTAL : 97 vases céramiques

Etude de principaux groupes céramiques

(par rapport aux caractéristiques des pâtes)

\section{Groupe I.}

Plusieurs vases qui semblent d'origine régionale utilisent une céramique beige assez fine, feuilleté avec inclusions calcaires et mica. Elle était utilisée, en général, pour des vases utilitaires ou de la vaisselle de table (lekanis, bol, cruche, amphore de table, pithos de taille moyenne) et probablement pour quelques tuiles.

\section{Groupe II.}

Un groupe varié de vases qui semble plutôt d'origine locale utilise une céramique brune rougeâtre granuleuse, feuilleté avec inclusions calcaires et mica; les formes sont les suivantes : lekanis, cruche, amphore de table, pithos de taille moyenne, et probablement tuiles.

Groupe III.

Céramique grise (étude incomplète ; à suivre). 


\section{LES FOUILLES}

\subsection{L'acropole du site}

(par B. Vergnaud, Ausonius, IFEA-USR3131)

A l'occasion de la campagne 2013, les recherches ont porté à la fois sur les parties basses et hautes de l'enceinte de la forteresse dominant le sanctuaire (Fig. 40). Les travaux ont d'abord été poursuivis dans le secteur de la porte (Fig. 41). En raison de la pauvreté de la stratigraphie dans la zone étudiée l'année passée, l'attention s'est focalisée sur la tour 8 dans l'espoir de mettre au jour des niveaux moins perturbés. Un second sondage a également été réalisé dans les fondations de la tour 7 pour tenter de récolter du matériel susceptible d'affiner la chronologie de la tour et par conséquent de la forteresse. Enfin, un nettoyage extensif du mur d'enceinte et de ses parements a été réalisé sur la quasi-totalité du périmètre fortifié afin de compléter le plan d'ensemble et de procéder au relevé de certaines sections encore mal connues. Ces nouvelles recherches dans la partie supérieure de l'acropole ont commencé par l'étude de la tour pentagonale située au Nord-Est de l'ensemble et dont la date de construction doit être ré-envisagée ${ }^{18}$.

\subsubsection{La porte et les tours}

\section{Les fondations de la tour 7}

Afin d'obtenir des précisions chronologiques sur la construction du système de défense et de déterminer les potentielles phases de modification, nous avons réalisé deux sondages contre les parements externes de la tour 7 (Fig. 42). En 2012, un premier sondage a été réalisé à l'angle sud-ouest de la tour. Il n'a pas livré de matériel datable. En 2013, un second sondage a été réalisé à l'angle de la tour 7 et du mur d'entrée (Fig. 43). Ces deux sondages nous ont permis d'obtenir une image claire des méthodes de fondations utilisées dans le secteur. En effet, le rocher a été creusé en profondeur avant la mise en place des murs afin de leur offrir un puissant ancrage en raison de la déclivité importante du terrain. La tour 7 , fondée de la sorte, servait donc de contrefort au mur de fortification. Le matériel du second sondage n'est pas très abondant, mais son contexte est bien assuré et son identification permet de discuter la chronologie établie ${ }^{19}$. Deux couches (2004-2005) composent le remplissage de cette tranchée de fondation qui est scellée par une couche d'abandon (2003) qui ne contenait aucun matériel postérieur à l'époque hellénistique. La couche supérieure (2004) a notamment livré deux fragments d'un bol à bord incurvé datable de l'époque hellénistique et plus précisément du $\mathrm{III}^{\mathrm{e}} \mathrm{s}$. av. J.-C. (Fig. 44) ${ }^{20}$. Le matériel de la couche 2005 est composé d'un fragment de tegula semblable à celui découvert par Lars Karlsson au sommet de l'acropole (AKW09-11) et daté de l'époque hékatomnide ${ }^{21}$. Cependant, la céramique pourrait être plus tardive et appartenir à la période suivante. Les découvertes effectuées dans le remplissage de la tranchée de fondation supposent que la forteresse pourrait avoir été en partie remaniée au cours de l'époque hellénistique (Fig. 45) 22 .

Ces indices en faveur d'une modification du système défensif après l'époque hékatomnide s'ajoutent aux constatations effectuées dans le cadre de la campagne 2012 au cours de laquelle une cour intérieure avait été découverte ${ }^{23}$. Il s'agit là d'un dispositif tactique destiné à contenir les éventuels assaillants qui auraient réussi à forcer l'entrée. Celle-ci constitue un ajout au système de défense original qu'il serait tentant de placer à l'époque hellénistique.

\section{La tour 8}

La tour $8(7,10 \times 7 \mathrm{~m})$ flanque l'entrée à l'Ouest (Fig. 41, 46-47). L'espace intérieur mesure 3,40 x $4,50 \mathrm{~m}$ et est circonscrit par des murs d'environ $1,30 \mathrm{~m}$ d'épaisseur implantés directement sur le rocher. Elle était accessible par un petit couloir

18) Mes remerciements chaleureux vont à mes très chers camarades, Habib Yayla, Mehmet Ali Sarıkaya, Murat Ergün, qui m'ont accompagné efficacement pendant toute la campagne. Le travail de terrain a également bénéficié de l'aide de Mélissa Cormier-Huguet (Université Bordeaux-Montaigne), Jesper Blid, Marco Ziff (Brown University), Kevin Trehuedic (Université Paris 12) et Katerina Stathi. Je remercie également notre topographe Pascal Lebouteiller et notre céramologue Vasilica Lungu pour leurs inestimables contributions aux recherches sur l'acropole. Enfin, je salue Olivier Henry pour l'énergie qu'il a consacrée à l'organisation de la campagne 2013.

19) Nous rappellerons que la construction de la forteresse est datée par L. Karlsson du deuxième quart du IV ${ }^{\mathrm{e}}$ s. av. J.-C. (Karlsson $2011: 217-252)$

20) Rotroff $1997: 341 \mathrm{n}^{\text {os }} 1001-1002$, fig. 63, pl. 76. Les bols 1001-1002 sont datables entre 290-250 av. J.-C. Pour un autre parallèle possible voir aussi Jones, 1950, 214, $\mathrm{n}^{\circ}$ 52, fig. 180. Parallèles courtoisement indiqués par V. Lungu.

21) Karlsson et al. 2010 : 73 fig. 29-30.

22) Une étude exhaustive du matériel des campagnes 2012 et 2013 sera réalisée lors de la prochaine campagne. Le rocher naturel n'a pu être atteint dans le sondage 2 en raison du manque d'espace.

23) Vergnaud $2013: 285-298$. 


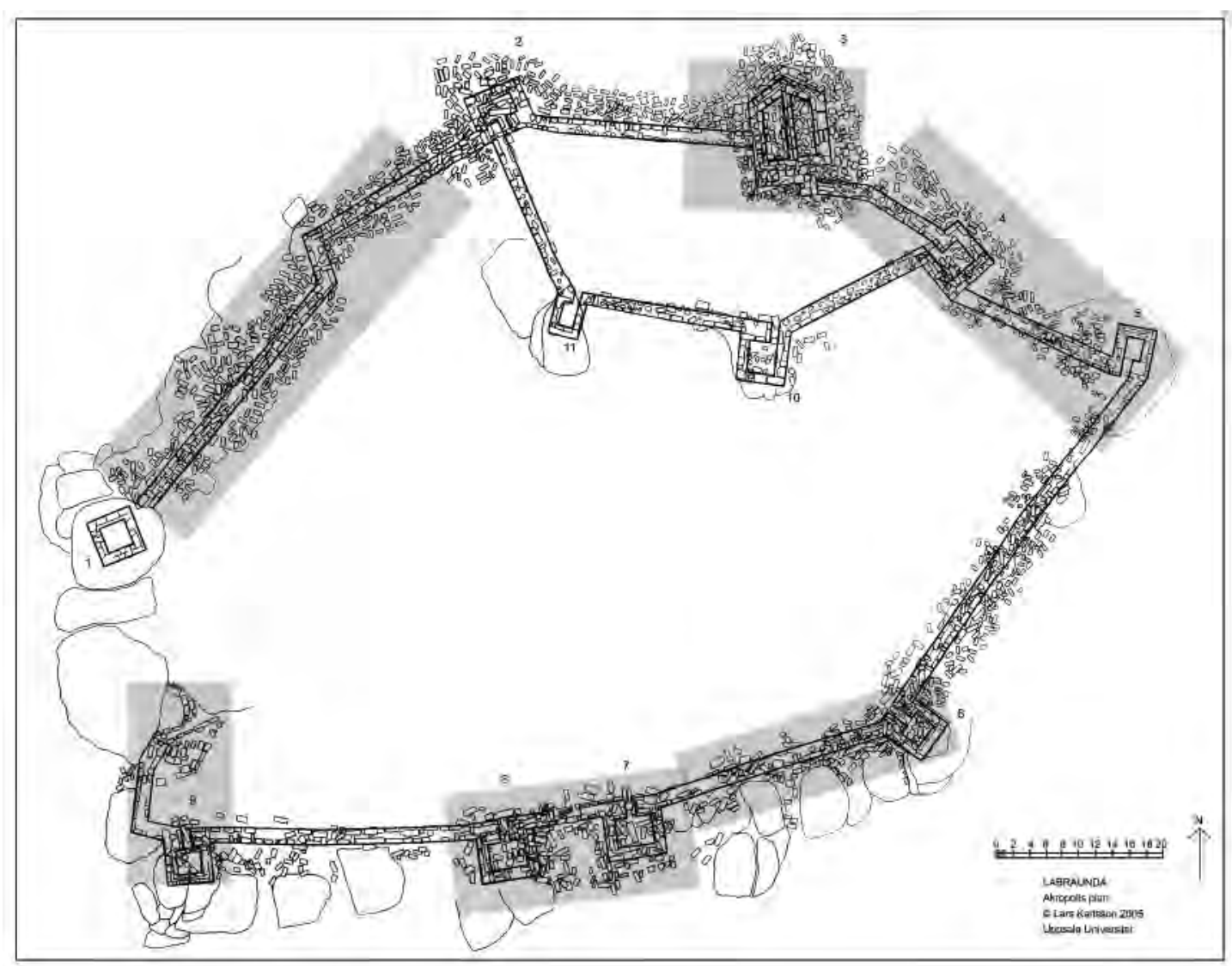

Fig. 40 : Plan de la forteresse et zones nettoyées (d'après L. Karlsson).

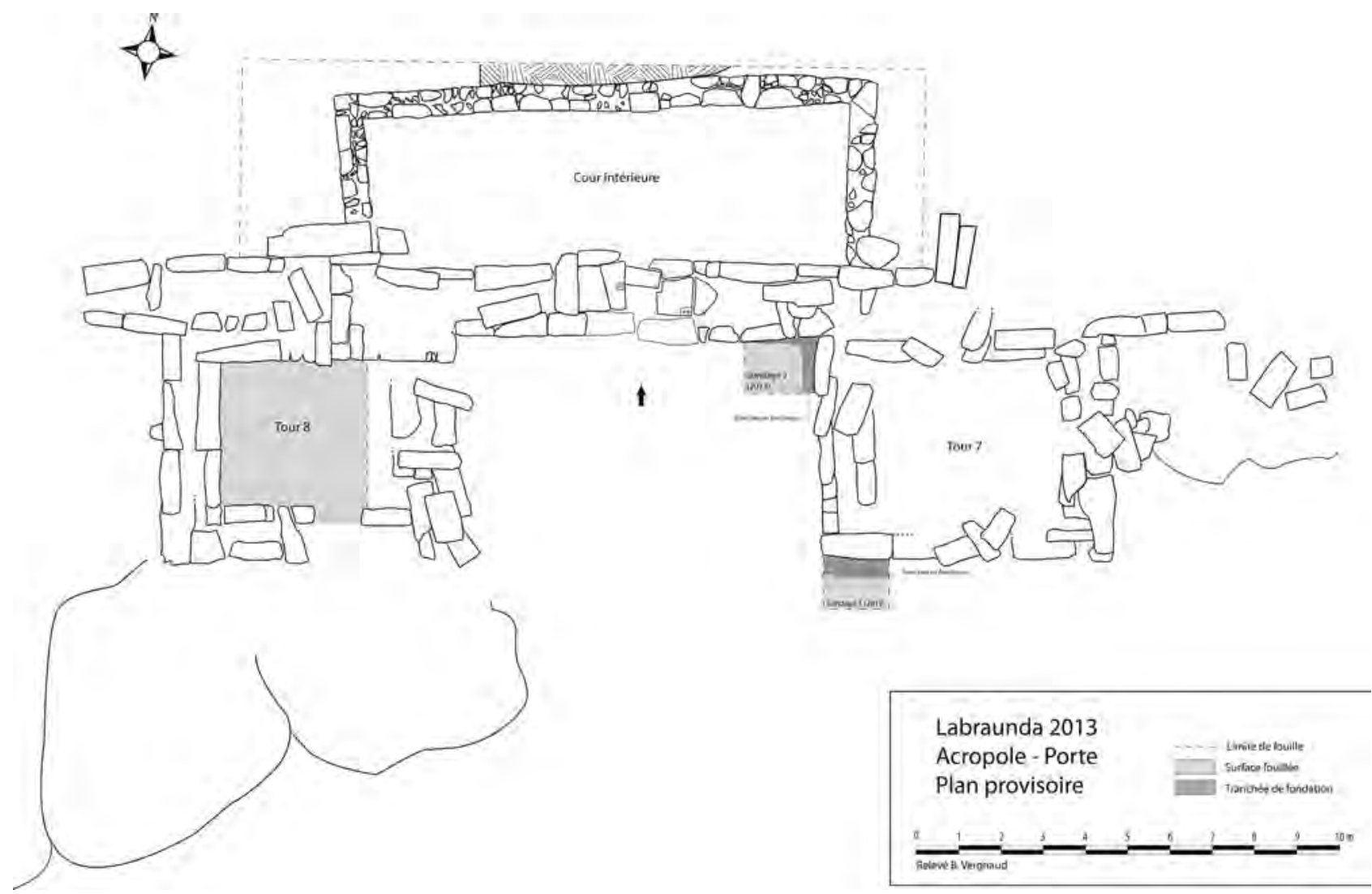

Fig. 41 : Plan provisoire de la porte (B. Vergnaud). 

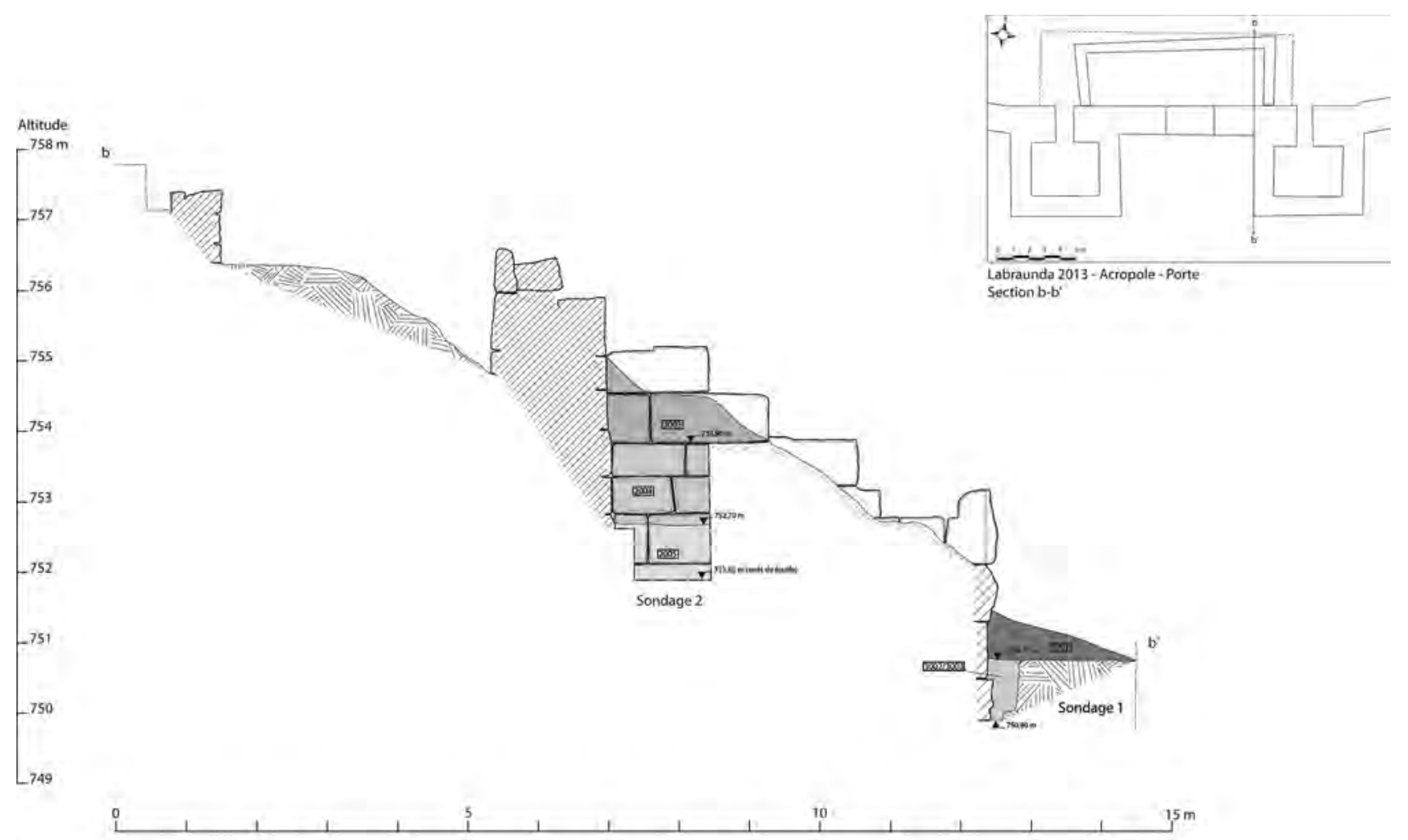

Fig. 42 : Section b-b' (B. Vergnaud).

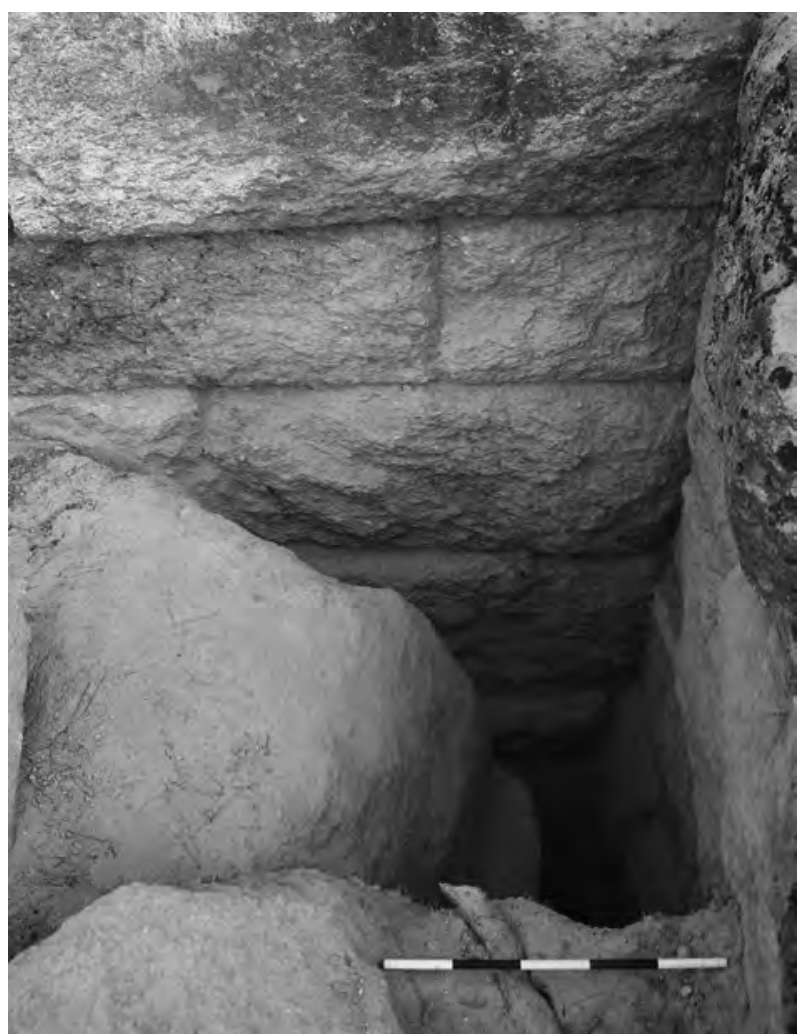

Fig. 43 : Tour 7. Sondage 2. (B. Vergnaud). 


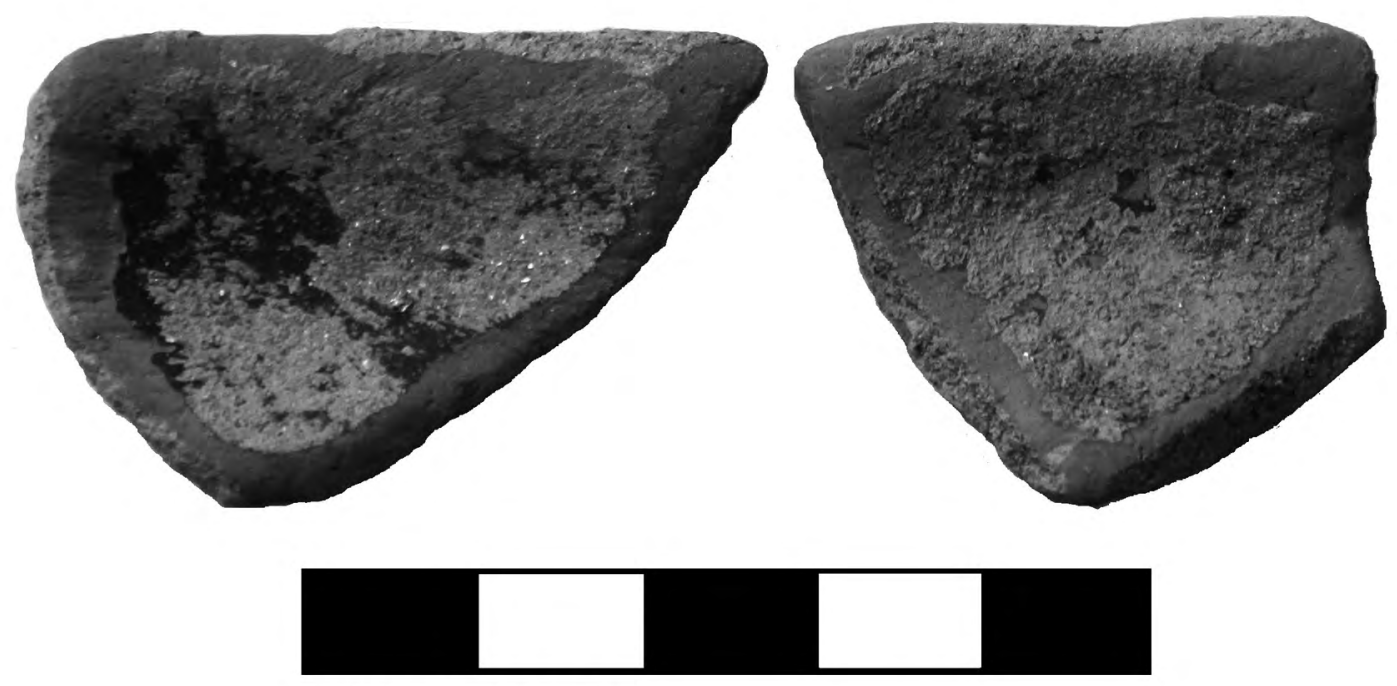

Lab 13-Ac-P-2004.1

Fig. 44 : Tour 7. Sondage 2. 2004. Fragments d'un bol à bord incurvé (B. Vergnaud).
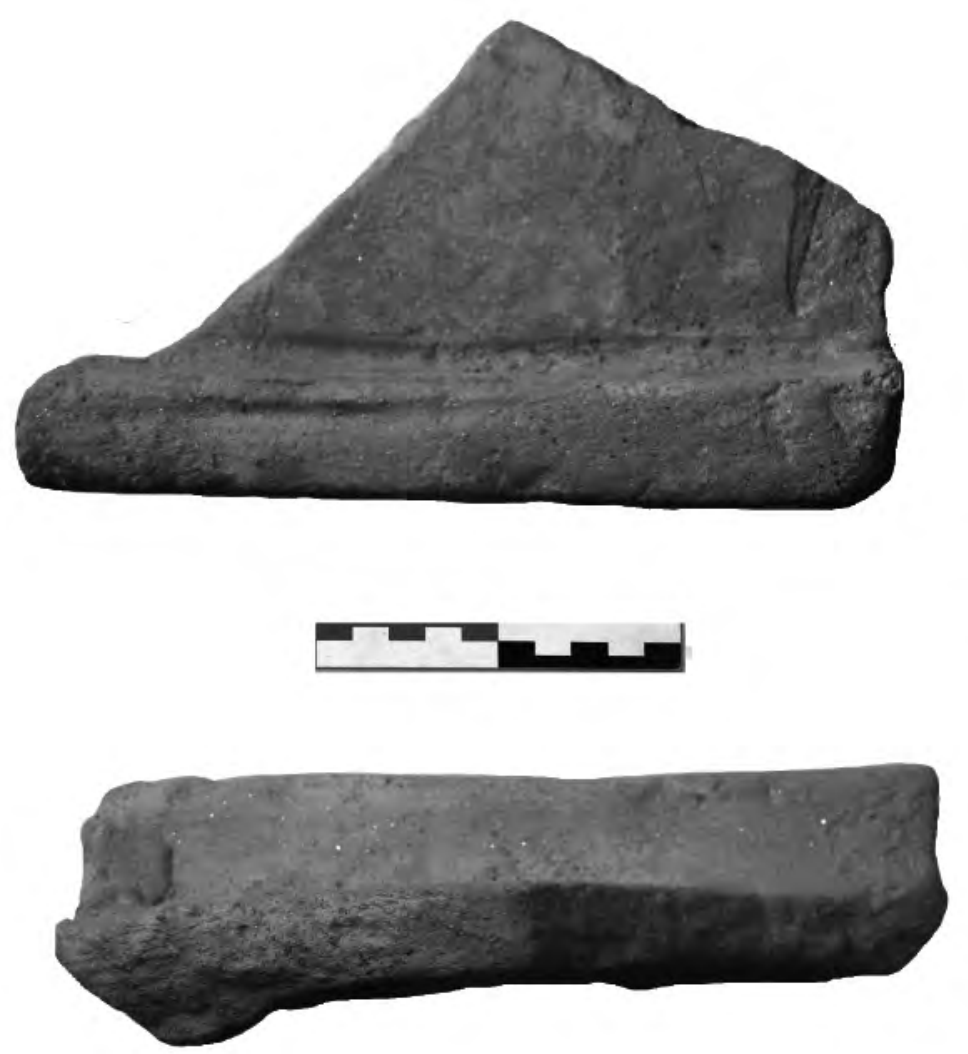

Fig. 45 : Tour 7. Sondage 2. 2005. Echantillon du matériel (B. Vergnaud).

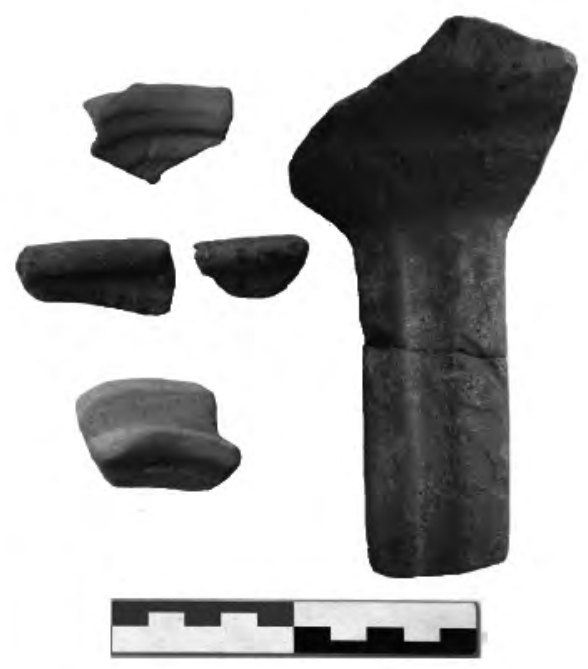




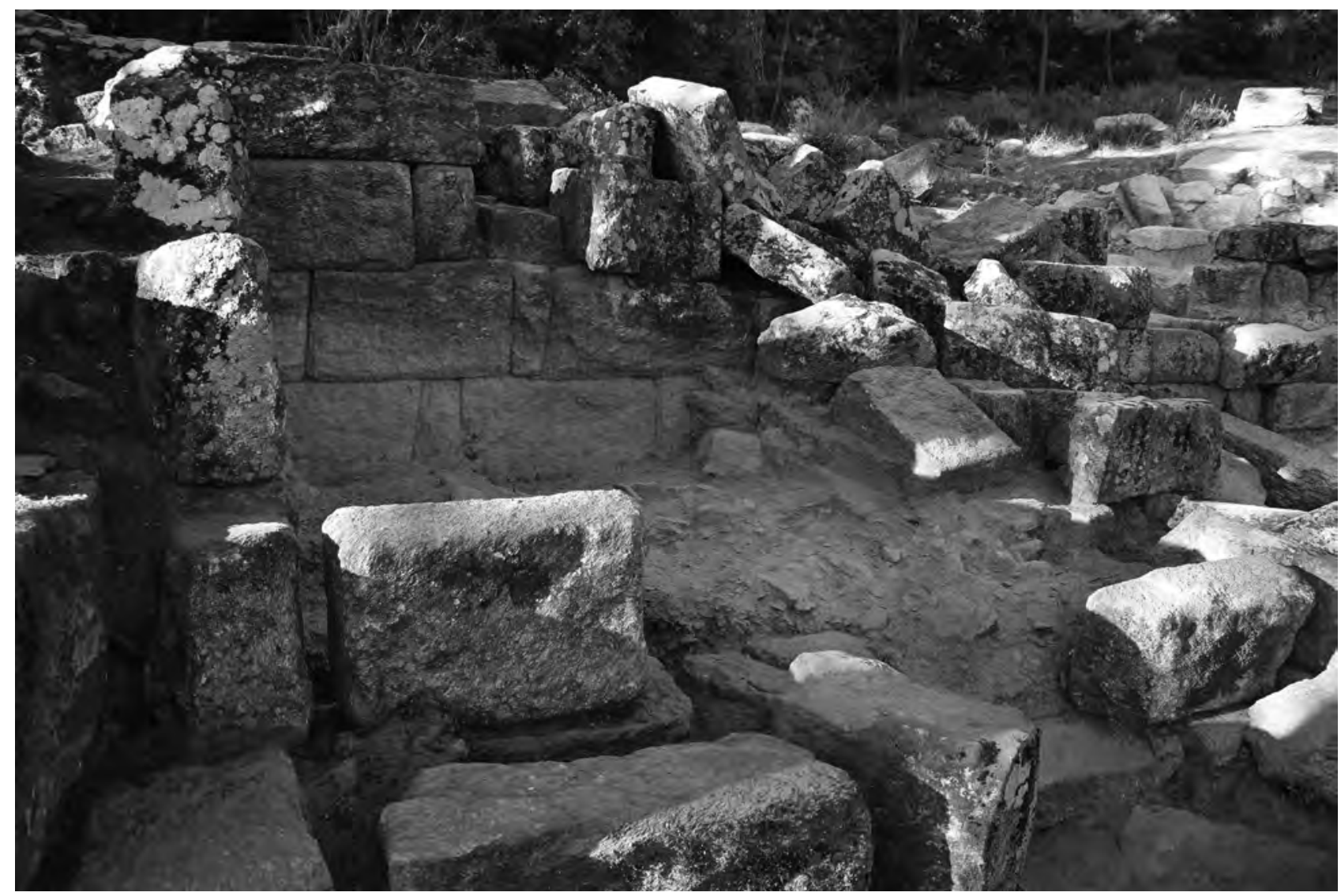

Fig. 46 : Tour 8. Vue vers le Nord-Ouest (B. Vergnaud).
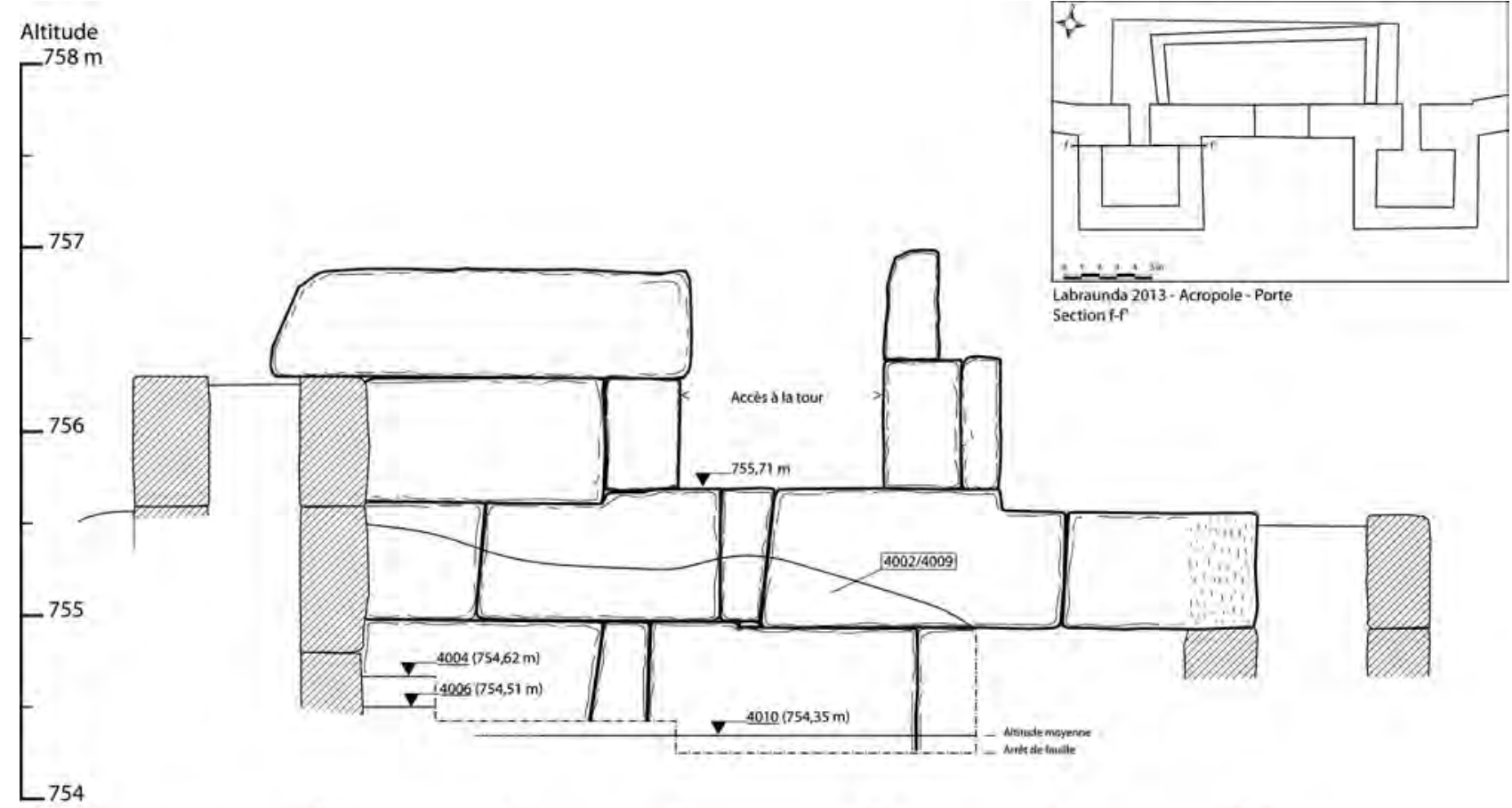

raunda 2013 - Acropole - Porte Section f-f

Releve et DAO; B. Vergnaud

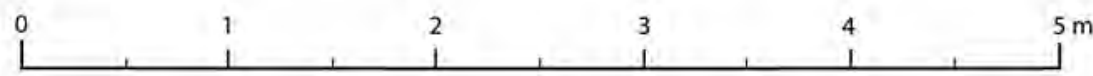

Fig. 47 : Tour 8. Section f-f' (B. Vergnaud). 


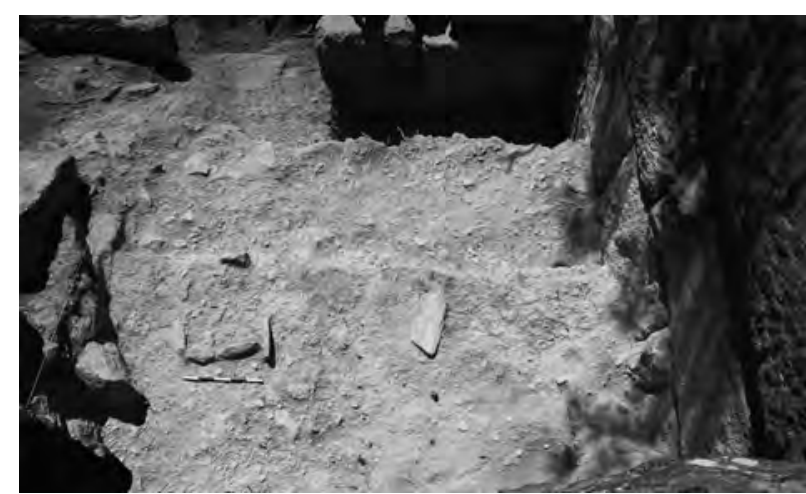

Fig. 48 : Tour 8.4010 et foyer 4012

(B. Vergnaud).

d'1 m de large. L'essentiel des travaux a porté sur la surface intérieure de la tour. Les fouilles stratigraphiques ont conduit à la mise au jour de plusieurs niveaux de sols en terre compactée (4004-40064003-4007-4010) qui ont été très altérés par l'effondrement de la construction. S'il a été nécessaire de les distinguer en raison de leur couleur, texture et altitude, ils paraissent appartenir au même horizon chronologique au regard du matériel qui leur est associé. Cette accumulation s'explique très probablement par les opérations de nivelage réalisées au cours d'une période assez courte. Ces niveaux de circulation étaient scellés par une épaisse couche de destruction (4002-4009) qui contenait des blocs de pierre de taille diverse et à l'intérieur de laquelle aucun matériel postérieur à l'époque hellénistique n'a été découvert. Parmi les niveaux de sols identifiés, seul le niveau 4010 a pu être mis au jour sur une grande surface (Fig. 48) ${ }^{24}$. Celui-ci reposait sur une couche de remblai d' $1 \mathrm{~m}$ d'épaisseur composée de petites pierres et de terre (4011) installée directement sur le rocher naturel préalablement aplani. Un sondage a été réalisé dans ce remblai à l'angle sud-ouest de la tour mais il n'a livré aucun matériel.

Une céramique presque complète qui peut être identifiée comme une amphore de table ou une hydrie a été découverte en association avec le niveau 4010 (Fig. 49). Elle est datée temporairement de la seconde moitié du $\mathrm{III}^{\mathrm{e}} \mathrm{s}$. ou du début du $\mathrm{II}^{\mathrm{e}} \mathrm{s}$. av. J.C.par comparaison avec le matériel hellénistique de Milet ${ }^{25}$. Un fragment de vase-passoire à vernis noir a également été mis au jour (Fig. 50). Il pourrait être daté $d u \mathrm{III}^{\mathrm{e}} \mathrm{s}$. par analogie avec une céramique

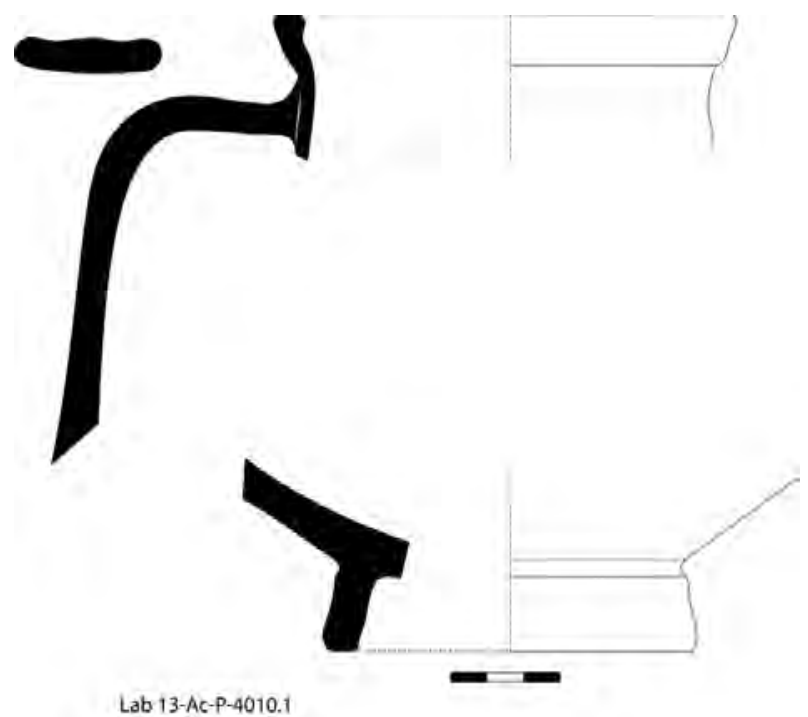

Fig. 49 : Tour 8. 4010. Hydrie ou amphore de table (V. Lungu).

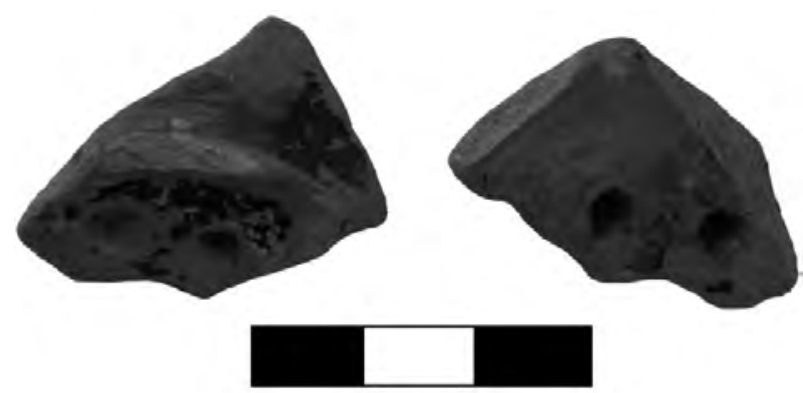

Fig. 50 : Tour 8. 4010. Fragment de passoire (B. Vergnaud).

similaire de l'agora d'Athènes ${ }^{26}$. Une monnaie en bronze représentant un cheval et un trident a également été découverte (Fig. 51). Il s'agit d'un type connu provenant de Mylasa et datable des $\mathrm{III}^{\mathrm{e}}-\mathrm{II}^{\mathrm{e}}$ s. av. J.C. ${ }^{27}$. Une tuile de type imbrex presque entièrement conservée retrouvée à plat sur le sol est également datable de l'époque hellénistique (Fig. 52). Elle est semblable aux exemplaires découverts par L. Karlsson à Ucalan Kule ${ }^{28}$. Le sol 4003, mis au jour à quelques centimètres au-dessus du sol 4010, a livré de la céramique qui appartient à la même fourchette chronologique. C'est notamment le cas du lopas découvert écrasé sur la surface de 4003 qu'il est possible de dater de la première moitié du $3^{\mathrm{e}} \mathrm{s}$. (Fig. 53) ${ }^{29}$.

24) Les sols 4004 et 4006 ont été repérés uniquement dans l'angle nord-ouest de la tour. Aucun matériel n'a été découvert en association avec ces niveaux.

25) Renseignement fourni par V. Lungu. Une datation plus précise sera fournie ultérieurement.

26) Rotrof $1997: 357, n^{\circ} 1183$, fig. 73 , pl. 87.

27) Information courtoisement fournie par K. Konuk. Se reporter également à Akarca 1959 : 15-18.

28) Karlsson et al. 2010 : 78-79, fig. 45

29) Halikarnassos 7 (Lopas G36). 


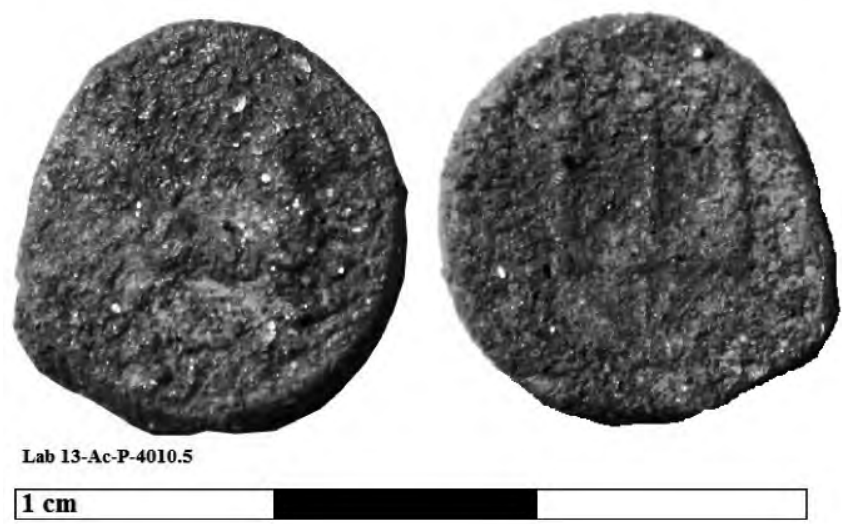

Fig. 51 : Tour 8. 4010. Monnaie de Mylasa (B. Vergnaud).

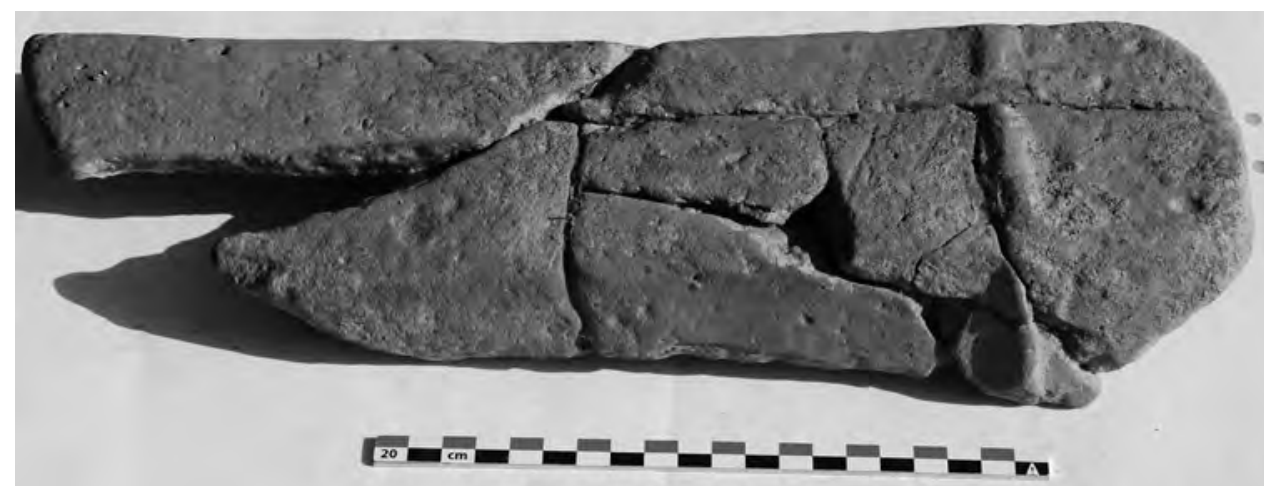

Fig. 52 : Tour 8. 4010. Imbrex (B. Vergnaud).

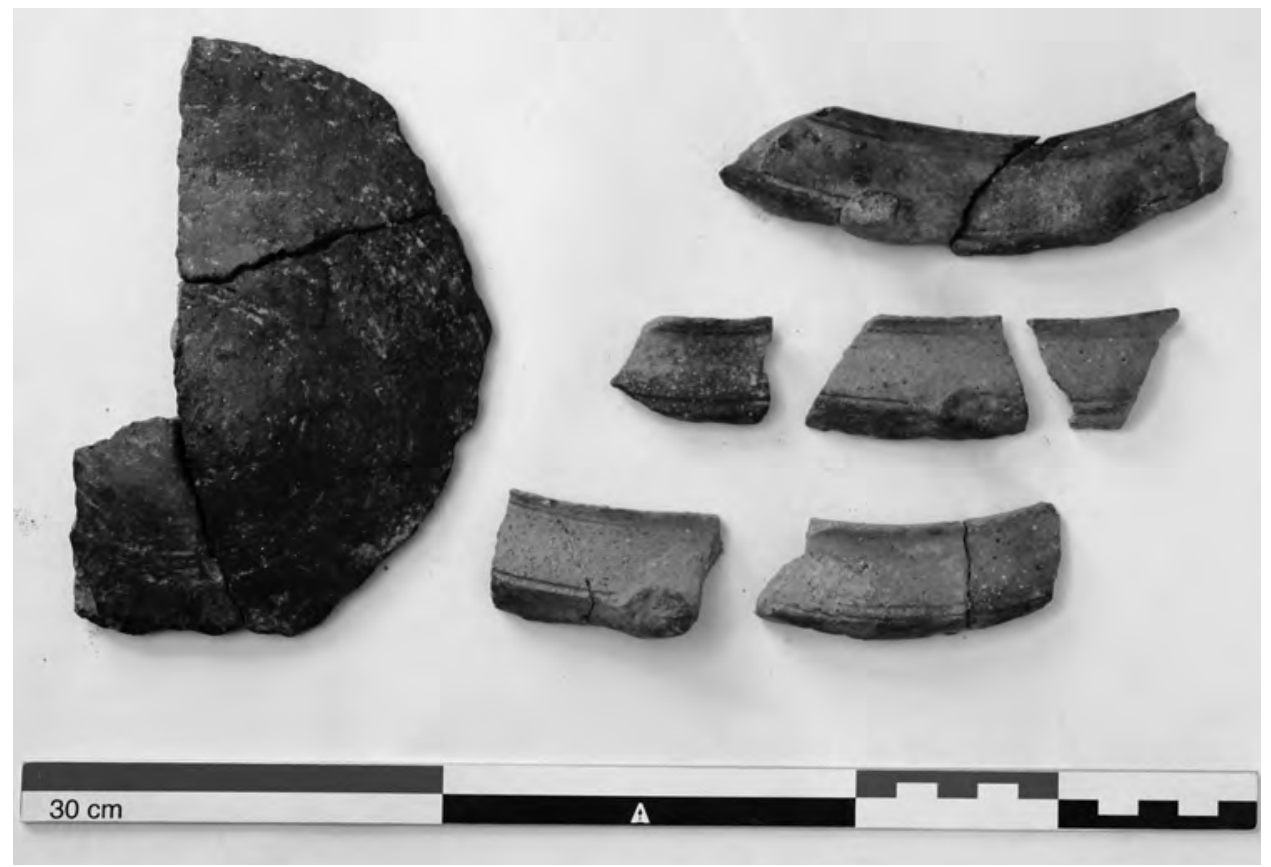

Fig. 53 : Tour 8. 4003. Lopas (B. Vergnaud). 


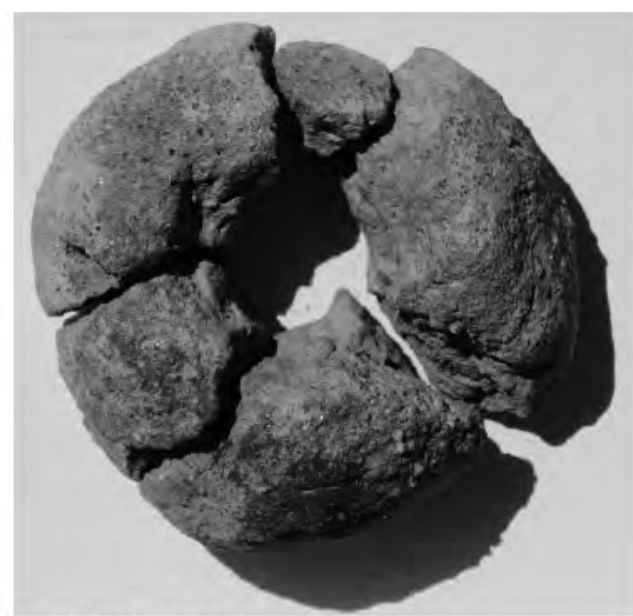

Lab 13-Ac-P-4008.1

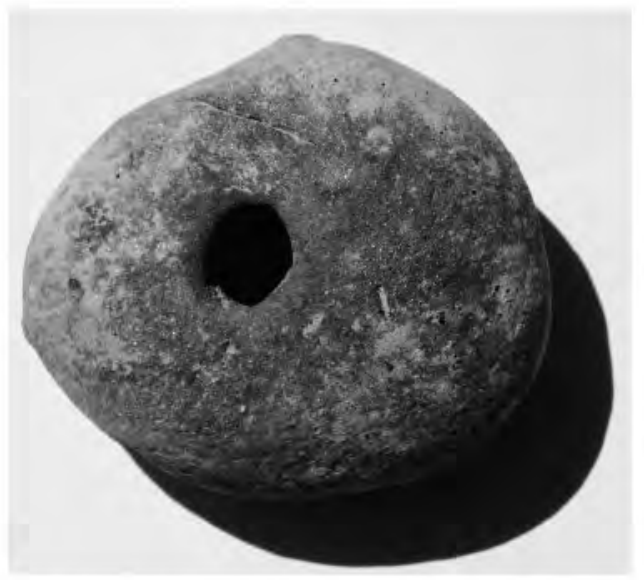

Lab 13-Ac-P-4008.5

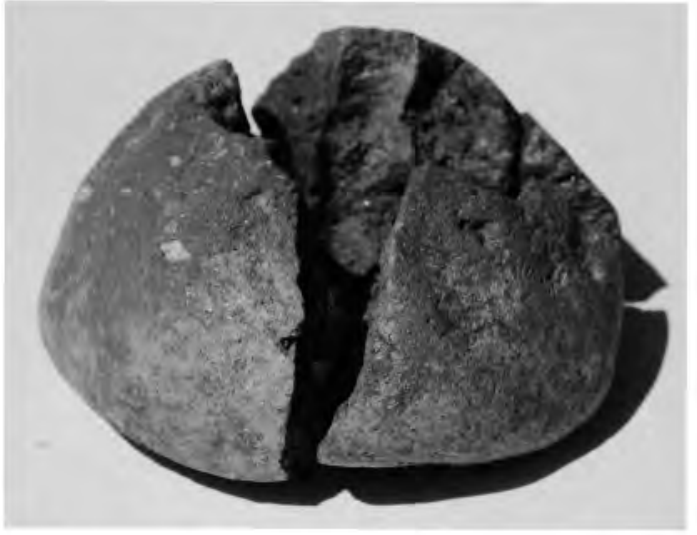

Lab 13-Ac-P-4002.2

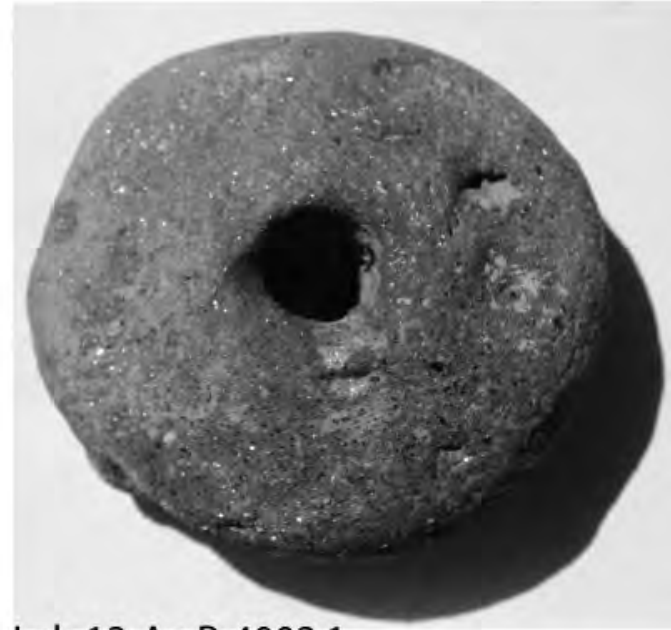

Lab 13-Ac-P-4002.1

Fig. 54 : Tour 8. Pesons (B. Vergnaud).

Les autres découvertes sont d'un intérêt limité pour les questions de datation mais nous renseignent sur les activités qui avaient lieu à l'intérieur de la tour. Un foyer en pierre de forme rectangulaire $(0,60 \times 0,68 \mathrm{~m})$, comparable à ceux mis au jour à Tepesar Kale et à Kepez Kule ${ }^{30}$, était associé au sol 4010 et peut être mis en relation avec les activités culinaires (Fig. 48). Plusieurs fragments métalliques ont également été découverts à proximité du foyer, mais puisqu'aucune scorie n'a été retrouvée, l'hypothèse actuelle est que ces éléments appartenaient aux huisseries des portes et des volets de la tour. La découverte la plus inattendue est celle de 4 pesons en terre cuite (Fig. 54). Trois d'entre eux présentent une forme ovoïde aplatie et l'un d'entre eux est tronconique. Cette découverte est inhabituelle. Aucune autre pièce de ce type n'a été découverte lors des fouilles précédentes sur l'acropole ou dans les autres tours du voisinage. Plus généralement, pesons et fusaïoles se rencontrent rarement dans un contexte militaire ${ }^{31}$. Ces pesons révèlent l'existence d'activités artisanales liées au tissage et leur présence renforce l'idée selon laquelle la tour était un lieu de vie.

Pour conclure ces remarques préliminaires sur le matériel, il faut noter que mis à part une partie des tuiles découvertes dans la couche de destruction

30) Tepesar (pièce 4b) : Karlsson et al. $2011: 27$ (fig. 3, 4b ; fig. 11). Kepez : Karlsson et al. 2012 : 52, fig. 3, 6-7.

31) Des pesons ont été découverts dans la tour de Cheimarou à Naxos (Morris et Papadopoulos $2005: 156$ ). Cela étant, les tours que l'on rencontre dans les campagnes grecques sont souvent associées à des corps de ferme et liées aux activités agricoles (stockage des denrées et protection des récoltes). La fonction militaire ou défensive des tours isolées peut donc s'avérer secondaire contrairement à celle des tours appartenant à un complexe défensif. Sur ces questions lire notamment Fachard 2012. 
(4002/4009), aucun fragment ne semble antérieur au début du $\mathrm{III}^{\mathrm{e}}$ s. av. J.-C. Le matériel tardif que l'on rencontre ailleurs dans le secteur de la porte n'est pas non plus représenté ${ }^{32}$. Ceci nous amène à formuler plusieurs remarques. La première est que la tour 8 n'a pas subi de réoccupation à l'époque byzantine et puisque la couche de destruction ne contient pas de matériel tardif, la destruction de la tour a eu lieu avant que la forteresse ne soit réoccupée entre le $\mathrm{XI}^{\mathrm{e}}$ et le XIII ${ }^{\mathrm{e}}$ s. ap. J.-C. ${ }^{33} \mathrm{La}$ seconde remarque concerne l'absence supposée de matériel d'époque hékatomnide qui impliquerait que la tour ait pu, sinon subir un réaménagement au cours de l'époque hellénistique, au moins avoir été complètement nettoyée à cette même époque. La présence de tuiles hellénistiques indique en tout cas que le toit de la construction fut recouvert au moins partiellement à l'époque hellénistique et probablement au cours du III ${ }^{\mathrm{e}} \mathrm{s}$. av. J.-C. si l'on considère que la majorité des fragments identifiables et la monnaie sont datés de ce siècle. La poursuite des fouilles dans ce secteur ainsi qu'une analyse exhaustive du matériel dans le cadre de la prochaine campagne nous permettra sans doute d'affiner ces datations.

Pour autant, les caractéristiques architecturales de cette tour se conforment assez bien à ce que l'on connaît de l'architecture défensive telle qu'elle était pratiquée à l'époque hékatomnide. Elle est fondée sur le rocher naturel et élevée le long d'une pente. Elle est chaînée au mur principal. Ses murs latéraux sont composés d'une alternance de carreaux et de boutisses à joints droits. Les blocs sont bossagés et parfaitement assisés. Les murs internes nord et ouest présentent occasionnellement des joints obliques (Fig. 47). Rien n'indique une quelconque réfection de la construction et aucun bloc à décrochement n'est visible ${ }^{34}$. Elle est d'un type simple, en saillie perpendiculaire par rapport au mur, et appartient à la catégorie des tours semi-pleines déterminée par J.-P. Adam. Ce dernier souligne d'ailleurs que les tours entièrement creuses n'apparaissent qu'à l'époque hellénistique ${ }^{35}$. Rien $\mathrm{n}$ 'indique donc une date tardive pour sa construction et il est possible de penser qu'elle faisait partie du tracé original. Il est difficile d'évaluer sa hauteur et celle des courtines adjacentes avec précision. J.-P. Adam considère que la hauteur des tours était généralement faible avec une moyenne de $4 \mathrm{~m}$ du sol au chemin de ronde ${ }^{36}$. Si, comme nous le pensons, la tour 8 de Labraunda comportait deux niveaux, sa hauteur peut être estimée à environ $8 \mathrm{~m}$ (toit compris) avec des courtines hautes de $6 \mathrm{~m}$ (en incluant un parapet d'environ $2 \mathrm{~m}$ de hauteur) ${ }^{37}$. La situation de la tour, construite sur une pente, ne nécessitait pas qu'elle soit plus haute pour assurer la défense de la porte.

\subsubsection{La tour pentagonale (tour 3 ), la tour 4 et ses environs}

En 2013, les travaux ont été étendus aux parties hautes de l'acropole et ont mené à un nettoyage extensif des murs de la forteresse dans le but de documenter plus précisément le tracé des murs, inclure dans le plan des éléments inédits et réaliser des relevés d'élévation. L'objectif est de détecter les possibles modifications du tracé au cours de l'histoire de la forteresse. Dans cette optique, les recherches se sont orientées vers une meilleure documentation de la tour pentagonale (tour 3, fig. 40, 55) pour laquelle une datation à l'époque hékatomnide apparaissait douteuse au regard des autres tours de ce type connues dans le monde antique. La tour en question est la plus imposante du circuit fortifié. Elle est longue de $12,70 \mathrm{~m}$ et large de 9,20 m. Un mur longitudinal divise l'espace interne en deux chambres et est ancré dans le bec de la tour qui pointe vers le Nord. L'orientation de la tour s'explique par la présence d'une haute colline de laquelle des attaques pouvaient être menées ${ }^{38}$.

Le plan particulier de cet ouvrage et ses caractéristiques architecturales suggèrent une datation à l'époque hellénistique. L'emploi d'un appareillage différent de celui utilisé dans le reste du périmètre

32) Vergnaud $2013: 285-298$

33) La réoccupation tardive de la forteresse a été mise en lumière par L. Karlsson dans le fortin situé au sommet de l'acropole (Karlsson $2011: 217-252$ ).

34) Les blocs à décrochements ou à emboîtement seraient une spécificité de l'époque hellénistique (Pimouguet-Pédarros $2000: 98$ ).

35) Adam $1982: 49$.

36) Ibid. : 105. Sur la hauteur des murailles, lire également Grandjean $2011: 411-412$. Il rappelle que si certaines murailles pouvaient dès l'époque archaïque excéder $8 \mathrm{~m}$ d'élévation, de nombreuses fortifications du IV $\mathrm{s}$. av. J.-C. et de l'époque hellénistique ne dépassaient pas 6-7 $\mathrm{m}$.

37) Cette estimation se base sur les calculs suivants : 2 m séparent le rocher naturel du seuil de l'entrée de la tour. On peut envisager que cette entrée s'élevait à également $2 \mathrm{~m}$ supplémentaires pour parvenir jusqu'au plancher du second niveau. La hauteur sous plafond du premier niveau peut être évaluée à $3 \mathrm{~m}$ (4 m moins le mètre de remblai sous le sol 4010). Si l'on envisage une hauteur similaire pour le second niveau, la hauteur de la tour est portée à $7 \mathrm{~m}$ auxquels ont peut ajouter $1 \mathrm{~m}$ pour la hauteur de la toiture, soit $8 \mathrm{~m}$.

38) Les présentes descriptions et les observations qui suivent sont résumées. Une description plus détaillée de la tour de Labraunda et quelques données sur les tours pentagonales sont disponibles dans Vergnaud (sous presse). 


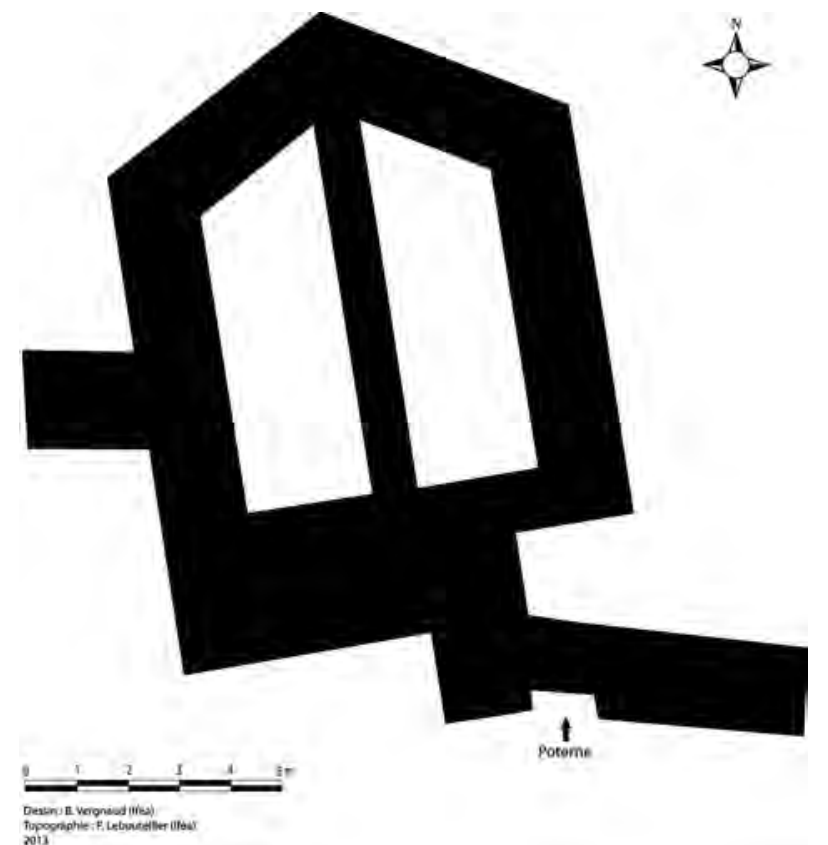

Fig. 55 : Tour pentagonale. Plan schématique (B. Vergnaud, P. Lebouteiller). est le premier indice. Les murs se composent en effet d'une alternance, à chaque assise, de carreaux et de panneresses (Fig. 56-57). Cette technique n'est pas employée dans l'architecture défensive hékatomnide où la pratique courante est d'alterner carreaux et boutisses. En revanche, elle apparaît de façon assez récurrente dans les constructions de l'époque suivante aussi bien dans les bâtiments civils, religieux que militaires ${ }^{39}$. La datation de cette tour est renforcée par comparaison avec les tours de même plan connues en Carie (Hyllarima, Harpasa), dans les régions voisines (Oinoanda, Samos) ou plus lointaines (Gadara) ${ }^{40}$. Bien que pour l'essentiel la datation de ces ouvrages repose sur des critères historiques, toutes sont datées au plus tôt à la toute fin du IV $\mathrm{e}$ s. av. J.-C. et leur apparition est généralement mise en relation avec le développement de la guerre de siège conséquent à la conquête macédonienne. L'étude de cette tour sera poursuivie dans la campagne suivante.

La présence de la tour pentagonale n'est pas le seul indice d'un remaniement des murs de la forteresse dans la partie supérieure de l'acropole. C'est en tout

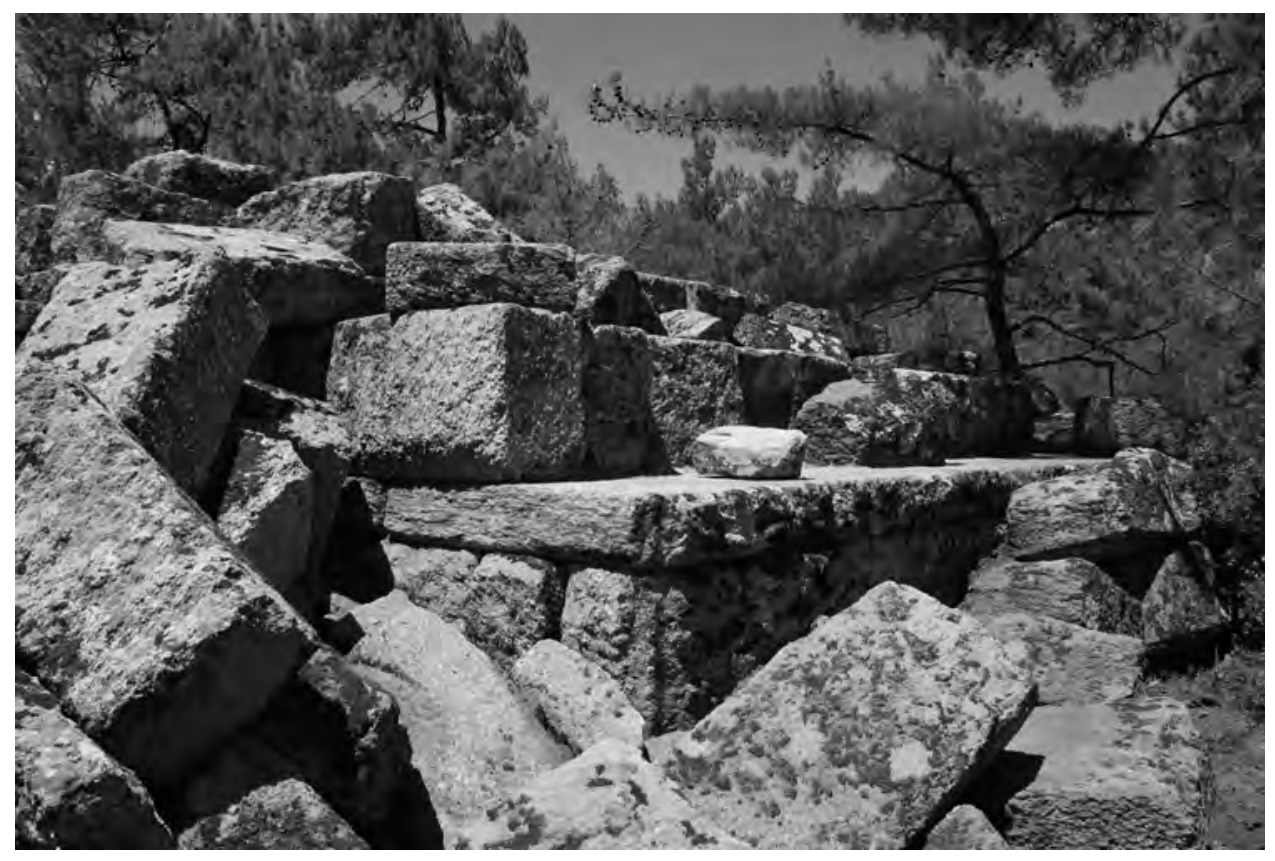

Fig. 56 : Tour pentagonale. Angle sud-est (B. Vergnaud).

39) Voir notamment Pimouguet-Pédarros (2000 : 94) qui évoque les exemples de Cnide et Keramos. Nous pouvons ajouter l'exemple des murs hellénistiques de Milet (von Gerkan 1935 : 65-66, en particulier fig. 38.). Le bouleuterion et le gymnase de Stratonicée, encore bien conservés, présentent également une alternance de carreaux et panneresses.

40) Sur Hyllarima voir Brun 1994 : 193-204. Sur Harpasa voir Debord et Varinlioğlu 2011 : 29-43 (sur la tour pentagonale : 39 43). Une autre tour pentagonale a été repérée à Alabanda mais il faut garder quelques réserves à son sujet. Voir la description dans McNicoll 1997 : 34. Sur Oionanda en Lycie, lire McNicoll 1997 : 120-126 (une nouvelle étude est en cours : http://www.dainst.org/fr/content/oinoanda-campaign-2011?ft=all). Sur Samos : Kienast 1978 : 85-95. Ce dernier date la tour pentagonale entre 310 et 290 av. J.-C. Sur Gadara : Hoffmann 2000 : 175-233. 


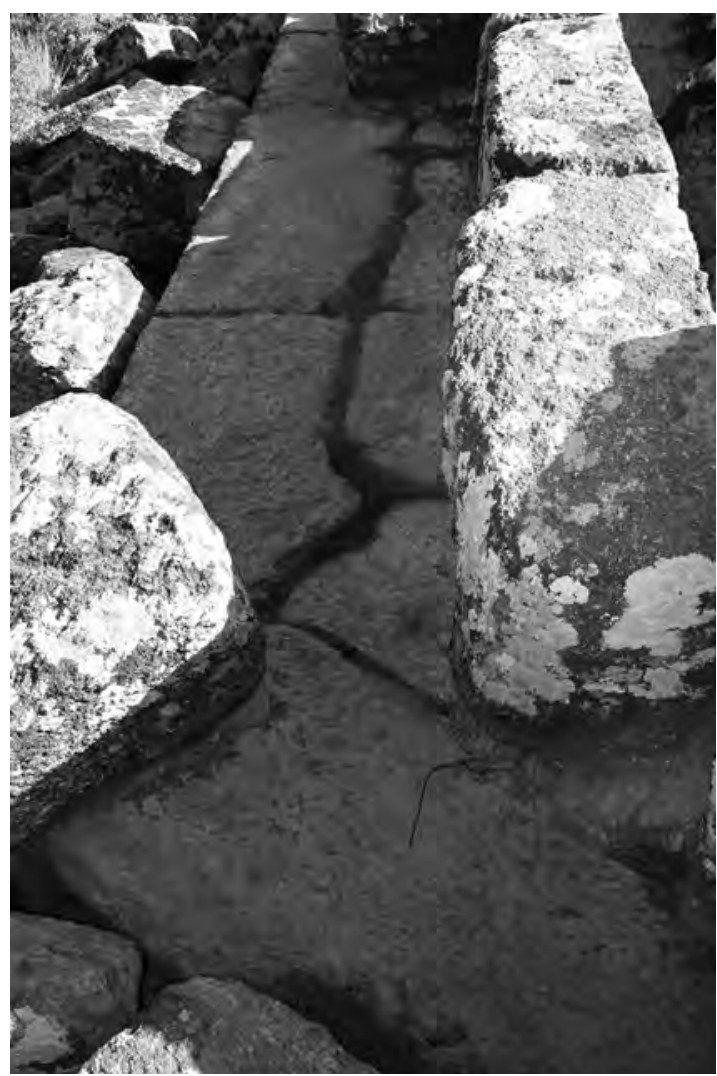

Fig. 57 : Tour pentagonale. Flanc est, vers le Sud (B. Vergnaud).

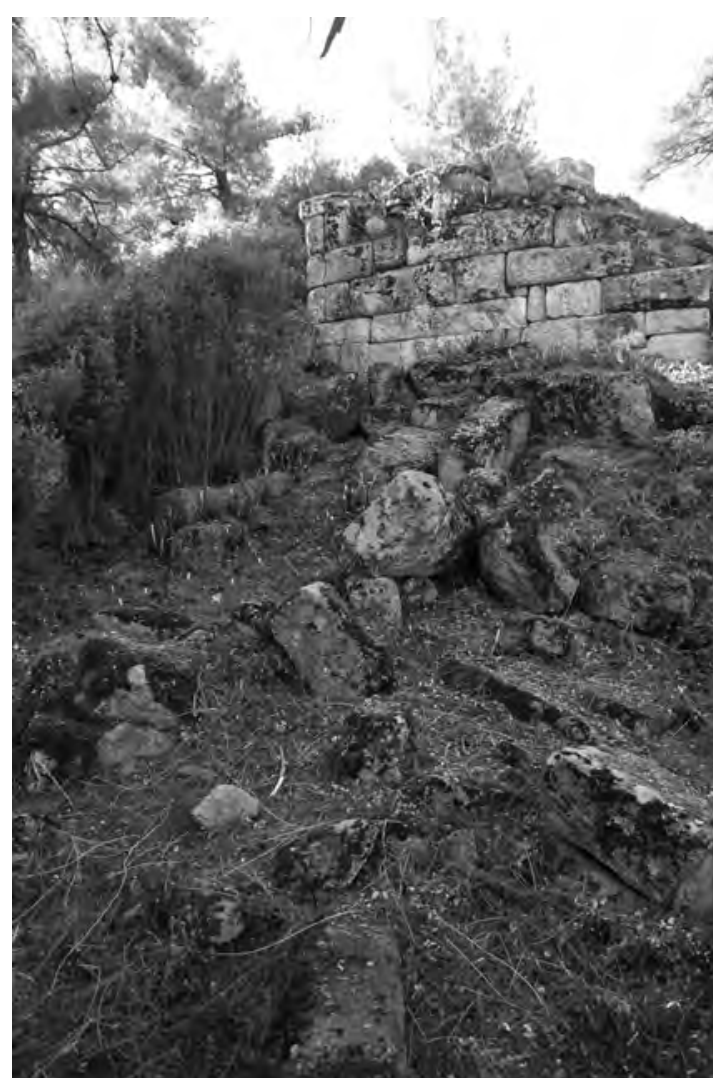

Fig. 58 : Tour 4 et courtine (premier plan). Vue vers le Nord-Ouest (B. Vergnaud).



Fig. 59 : Tour 4. Parement extérieur.

Ravalement du bossage (B. Vergnaud). 


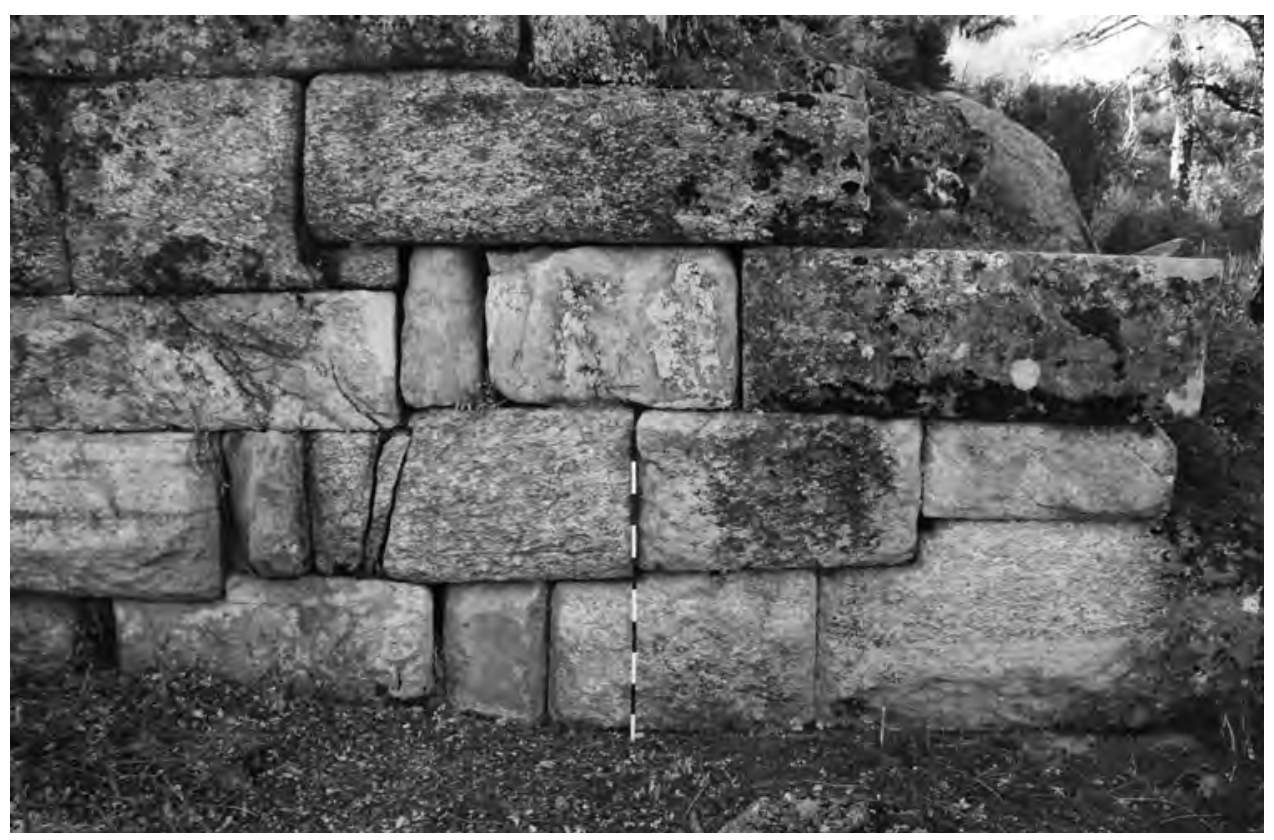

Fig. 60 : Tour 4. Parement extérieur (B. Vergnaud).

cas ce que suggèrent les observations réalisées dans le secteur de la tour 4 située à proximité de la tour pentagonale (voir Fig. 40 et 58). La tour 4 est bien chaînée au mur du fortin mais elle n'est pas chaînée au mur d'enceinte principal qui descend vers la face est de l'acropole en direction de la tour 5. Celui-ci s'accroche au parement frontal de la tour 4 , comme l'indiquent les creusements dans le bossage qui a en partie été ravalé à cet effet (Fig. 59). En outre, le parement extérieur de cette tour ne présente pas la régularité que l'on remarque dans les autres murs de la forteresse. Les assises sont biaises ou présentent des décrochements et les blocs sont de dimensions variables (Fig. 60). Ces irrégularités ainsi que le ravalement du parement suggèrent au moins une réparation de la construction. Il est cependant possible d'imaginer que cette tour et la courtine adjacente aient subi les effets du programme de reconstruction qui se caractérise au moins par l'incorporation de la tour pentagonale.

\section{Conclusion}

La seconde campagne de recherche sur l'acropole de Labraunda nous a permis de mettre en lumière l'importance de l'occupation de la forteresse à l'époque hellénistique et de présenter plusieurs indices en faveur d'un renforcement de ses défenses au cours de cette période. Le matériel rassemblé dans le cadre des fouilles de la tour 8 suggère une occupation très dense au $\mathrm{III}^{\mathrm{e}} \mathrm{s}$. av. J.-C. mais les ob- servations architecturales ne laissent pas penser à une modification de la construction. En revanche, la découverte de tessons datables du $\mathrm{III}^{\mathrm{e}}$ s. av. J.-C. dans la couche de comblement 2004 de la tranchée de fondation de la tour 7 (sondage 2) permet de supposer que l'édifice a pu subir des modifications. Il reste à déterminer s'il s'agit d'une réparation localisée de la tour ou si ce remaniement concerne la totalité de la porte. L'existence d'une phase de renforcement des défenses est plus évidente au sommet de l'acropole. Elle se caractérise par l'incorporation d'une grosse tour pentagonale dont l'appareillage est caractéristique de l'époque hellénistique. Les quelques observations effectuées dans le secteur de la tour 4 vont également dans le sens d'une modification du tracé des murs de la forteresse. Il est cependant encore trop tôt pour dire si elle est intervenue au moment de la construction de la tour pentagonale. Il est donc encore difficile d'évaluer l'ampleur de ce changement. Quoi qu'il en soit, ces nouvelles données permettent de revoir la datation de cet ouvrage dont on pensait qu'il avait été érigé au cours d'un seul et même programme de construction à l'époque hécatomnide. En outre, ces découvertes sont concordantes avec celles effectuées par L. Karlsson aux environs de Labraunda. Il a pu démontrer assez clairement que le réseau défensif établi le long de la voie sacrée reliant Mylasa et Labraunda a connu deux phases différentes. L'exemple le plus évident est celui du Tepesar Kale où la défense n'était à l'origine composée que d'une grosse tour carrée érigée à 


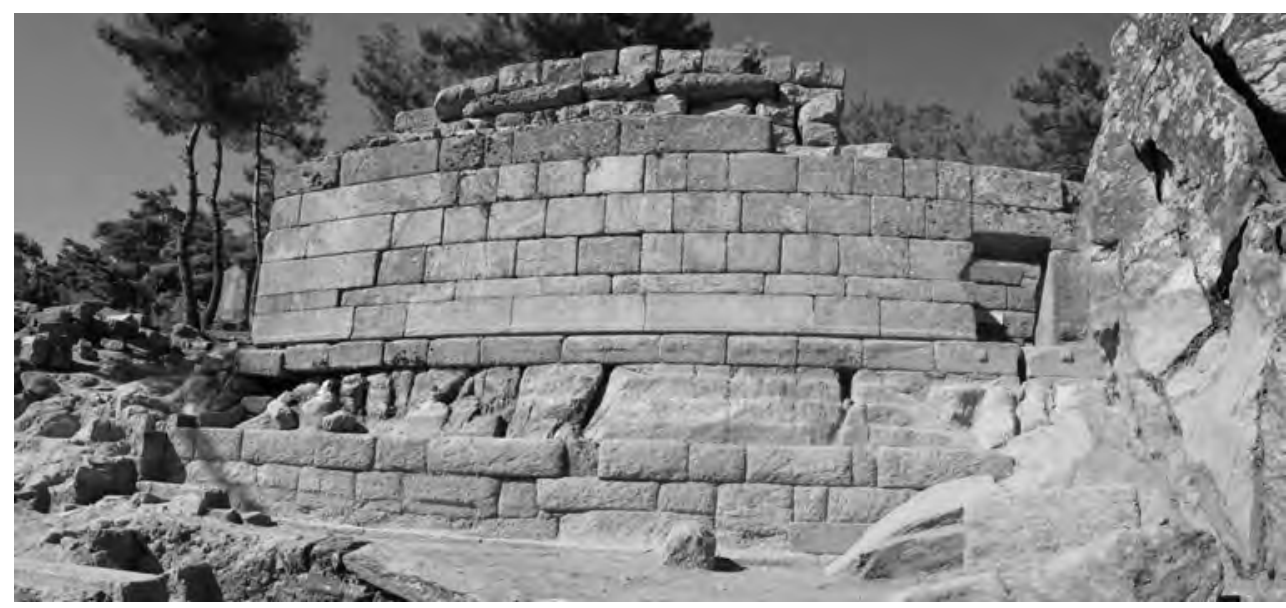

Fig. 61 : Vue générale de la tombe monumentale depuis le Sud

(la déformation est due à l'optique utilisée) (photo : O. Henry).

l'époque hécatomnide avant qu'une seconde tour et une série d'annexes lui soient adjointes, vraisemblablement au cours du III ${ }^{\mathrm{e}}$ s. av. J.-C. ${ }^{41}$

\subsection{Le bâtiment en $P i$ sous la tombe ${ }^{42}$ monumentale}

En 2012, l'opération de nettoyage au Sud de la tombe monumentale de Labraunda avait révélé un très large bâtiment en $P i$ dont on soupçonnait qu'il pouvait s'agir d'un autel monumental érigé au cours de la période hellénistique et dédié au propriétaire de la tombe (Fig. 61).

En 2013, nous escomptions poursuivre la fouille du bâtiment et mettre au jour les fondations de ce bâtiment. Une telle fouille aurait permis non seulement de fixer la chronologie des structures mais aussi de comprendre leur fonction. Compte tenu du faible temps que j'ai pu consacrer à la fouille (mon activité d'organisation ayant été particulièrement chronophage), il a été décidé de limiter notre opération à un sondage profond plutôt que d'entreprendre le dégagement complet de l'espace circonscrit par le bâtiment en $P i$.

Le sondage a été positionné au centre de la structure, au contact du niveau de blocs sur lequel nous nous étions arrêtés l'année dernière (Fig. 62). Mesurant 2,80 m de large, nous avons atteint la roche sur la quasi-totalité du sondage. Il apparaît que les blocs soutenant les banquettes du bâtiment en $P i$ sont directement posés sur le rocher qui a été entaillé de manière à offrir une base de fondation parfaitement horizontale à l'assise de blocs. On repère trois niveaux stratigraphiques dans le remplissage des structures de fondation (Fig. 63). Le niveau supérieur, correspondant au niveau du sol du bâtiment en $P i$ présente un large nombre de fragments de tuile et assez peu de matériel céramique. Une monnaie de Rhodes, trouvée à la base de ce niveau, daterait l'ensemble de la fin du III ${ }^{\mathrm{e}} \mathrm{s}$. - début du $\mathrm{II}^{\mathrm{e}}$ s. av. J.-C. (Fig. 64) ${ }^{43}$. La couche intermédiaire est relativement fine. Elle est plus meuble et argileuse que la précédente. On note une forte concentration de tuiles et de céramiques dans la partie nord-est du sondage. La dernière couche, qui correspond probablement à la mise en place du bâtiment en $P i$, repose sur le rocher. Elle diffère radicalement des autres. Il s'agit d'une couche très meuble, gris/noir, comportant un important matériel céramique souvent brûlé et des végétaux (graines) carbonisés. Une monnaie mise au jour dans la partie sud-ouest du sondage, entre le rocher et cette couche, daterait ce niveau de la fin du IV s. av. J.-C. (Fig. 65) ${ }^{44}$.

Dans la même partie sud-ouest du sondage, on repère que le rocher a été creusé circulairement. Il pourrait s'agir d'une fosse de type bomos destinée à recevoir des sacrifices.

41) Karlsson $2011: 224$.

42) Les travaux de terrain cette année sur ce bâtiment ont été placés sous la responsabilité de Mélissa Cormier, dont l'efficacité a été redoutable.

43) Chalque qui est daté des années 205-188 av. J.-C. dans SNG Keckman I : 599sq. par Richard Ashton; et de "Late third cent. B.C." par le même Ashton dans The Coinage of Rhodes, 408-c. 190 B.C.

44) Monnaie de type macédonien. Au droit un bouclier macédonien orné d'un gorgoneion de face, sur le tour, alternance de croissants pointées et de points. Au revers, les inscriptions B-A de part et d'autre d'un casque ; en bas à gauche une double hache, à droite $k$. La monnaie est attribuée aux frappes de Milet ou Mylasa et daterait vers 320 av. J.-C 

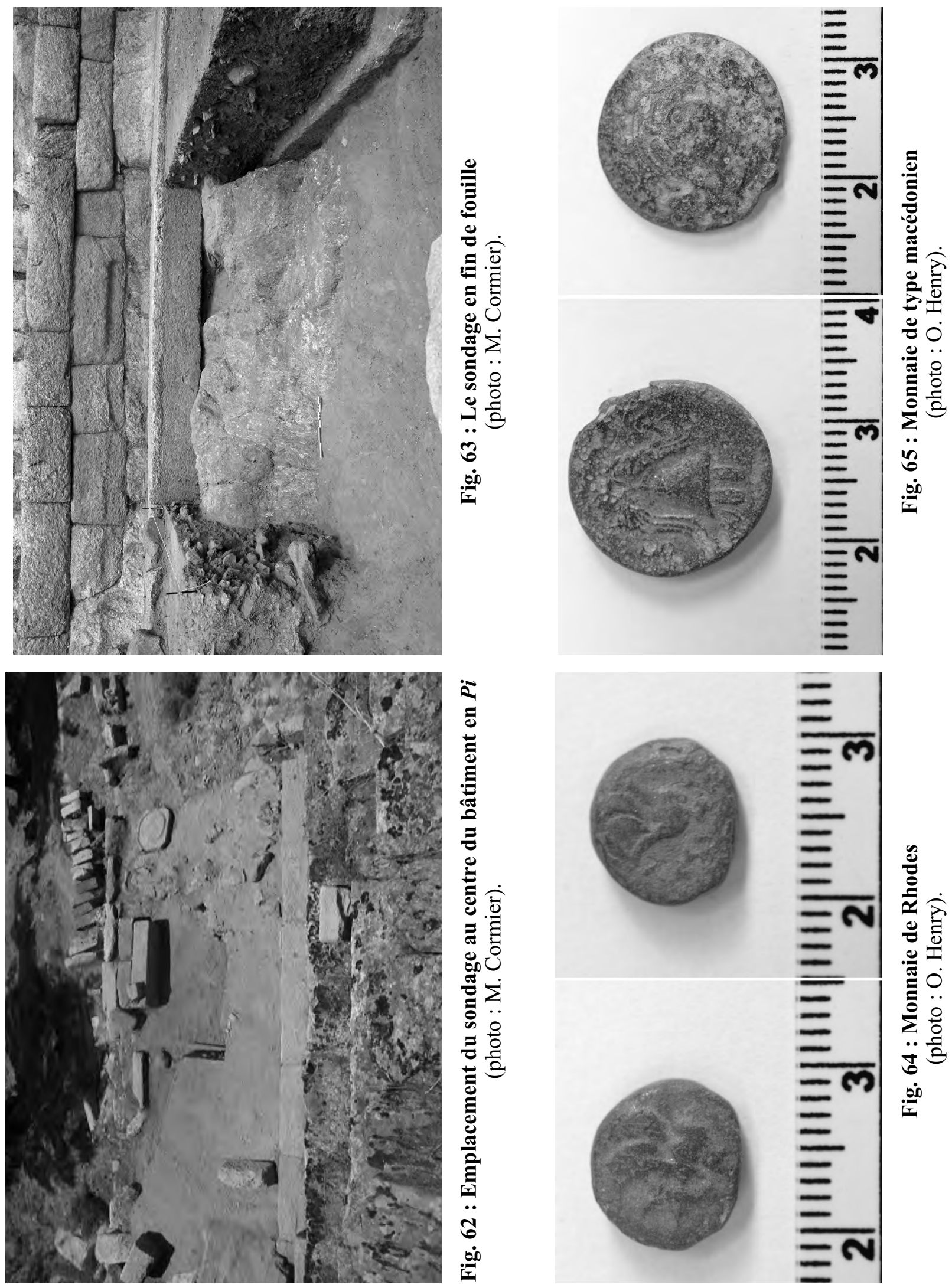


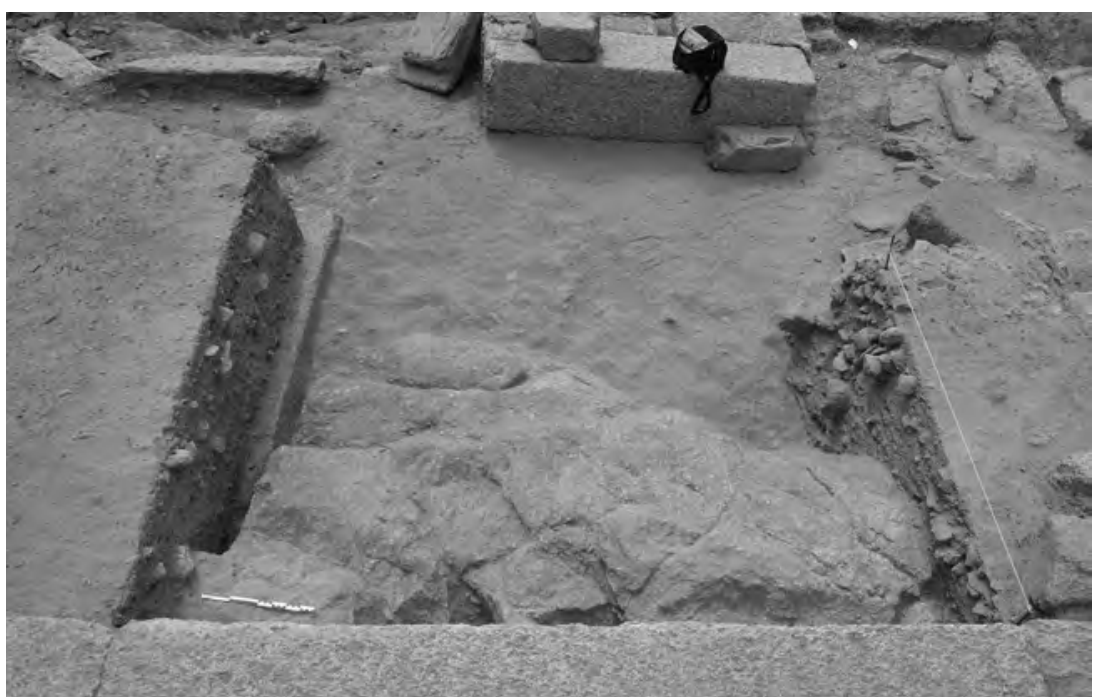

Fig. 66 : Le sondage vu du Nord, à gauche on repère l'extrémité d'une structure antérieure (photo : O. Henry).

$\mathrm{Au}$ fond du sondage, $72 \mathrm{~cm}$ sous le niveau du sol appareillé de la structure en $P i$ et sous la limite est de la tranchée, on a mis au jour ce qui semble apparaître comme étant une phase de construction antérieure. Il s'agit d'un mur axé nord-sud (perpendiculairement à l'axe du bâtiment en $P i$ ) composé d'un large blocs de gneiss entièrement inséré dans le rocher (Fig. 66). Des marques de taille sur la face d'attente de ce bloc indiquent clairement la présence originelle d'une assise supérieure perpendiculaire. Dans l'état actuel du sondage, qu'il faudra poursuivre vers le Sud et l'Est, nous n'avons aucune indication concernant la date ou la fonction de cette construction antérieure. Celle-ci doit dater d'une période antérieure à la conquête macédonienne. Cette découverte vient confirmer l'hypothèse que nous formulions l'année dernière après l'analyse des structures de la pente sous la tombe monumentale, tout en en rabaissant la date. Il semble donc qu'un large remaniement ait été opéré vers la fin du $\mathrm{III}^{\mathrm{e}} \mathrm{s}$. av. J.-C. dans la zone, entre le podium de la tombe et la terrasse du temple, probablement a l'occasion de la réutilisation de la tombe. Ce réaménagement a vu la construction du grand bâtiment en $P i$ (qui oblitéra un bâtiment plus ancien, démonté pour l'occasion) et probablement par la même occasion la série de murs de terrasse permettant de relier physiquement la terrasse du temple à la tombe monumentale.

\subsection{The M terrace project (par J. Blid et}

\section{R. Hedlund, Université d'Uppsala)}

It is apparent from the evidence at hand that the sanctuary of Labraunda retained its status as the centre of intense activity in the Roman age. A number of studies have treated finds from this period, most notably the works of Crampa, Gunter, and Liljenstolpe \& von Schmalensee ${ }^{45}$. However, the architectural remains from the Imperial period in Labraunda have not been scrutinized comprehensively until now. A number of buildings are currently studied in this project. Preliminary investigations of the preserved architectural remains were done during the field campaign in $2011^{46}$. In 2012, we initiated a more systematic architectural survey of the Roman remains found on the Temple Terrace, and its significance for the layout and functions of the sanctuary ${ }^{47}$.

The fieldwork of $2013 \mathrm{had}$ two aims. The initial objective was to continue the documentation of architectural members unearthed during the first Swedish excavations between 1948 and 1953. During the previous campaigns, we have focused only on the architectural remains that we attributed to the so-called Terrace $M$ (the built terrace south of the Temple Terrace); however, this year we have expanded the study to include other Hellenistic and Roman buildings on the eastern side of the Temple Terrace and Terrace Y (directly east of the Temple Terrace).

The second aim of the project was to excavate parts of an elongated building which occupies the whole of Terrace $\mathrm{M}$, and is referred to by us as Building M (Fig. 67). This represents one of the most monumental building complexes within the temenos of Labraunda, and the building exhibits clear Hellenistic as well as Roman construction phases. To date, Building $\mathrm{M}$ has not been thoroughly excavated; however, some conclusions can be inferred

45) Cf. Labraunda II:5 ; Labraunda III:2 ; Liljenstolpe and von Schmalensee 1996.

46) Karlsson et al. 2012:85.

47) Henry et al. $2013: 327-336$. 


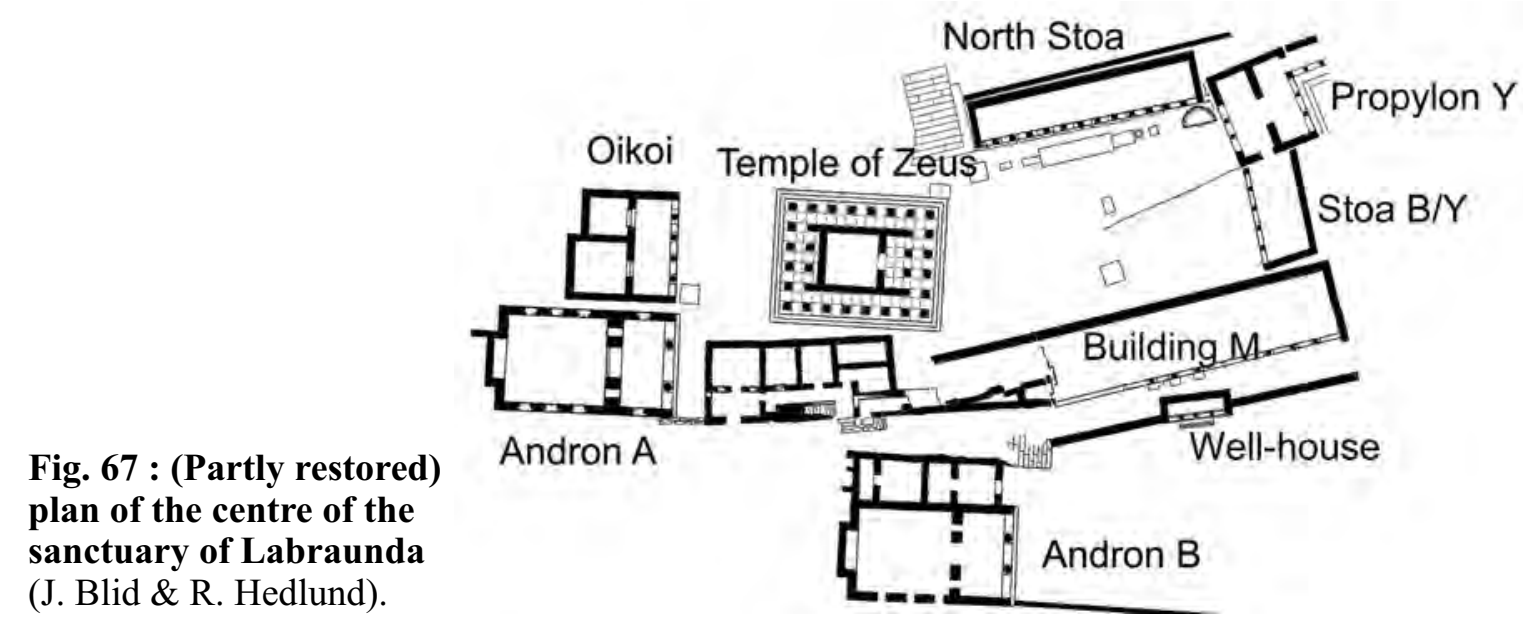

from various earlier documentations. Drawing on studies of the architectural members preserved from Building M, and the layout of the terrace where this building stood, we have previously proposed an architectural layout in the shape of a multi-storeyed covered hall in the Roman period. This hall did, however, replace a previous Hellenistic stoa. The function(s) of this building throughout its history, unfortunately, is still unclear. The aim of the excavations in 2013 was to establish the chronology, function analysis, and architectural properties of Building $\mathrm{M}$.

\subsubsection{Architectural survey on Terraces $B, M$, and $Y$}

The project commenced with the documentation of architectural members excavated during the late 1940 s and early 1950 s. These are mainly present on the Temple Terrace (north of Terrace M), but this documentation also included the measuring of architrave/frieze blocks, cornices, sima-blocks, and columns originating from Building $\mathrm{M}^{48}$. The documentation further included a number of Hellenistic and/or Roman anta-blocks that we have divided into two subtypes. A number of other architectural fragments from Terrace Y, originating from the socalled Propylon Y, were also surveyed.

The result is that we are able to present tentative reconstructions of two buildings on the eastern side of the Temple Terrace. Of these, the most substantial remains are from Propylon Y, situated in the NE corner of the Temple Terrace. Propylon Y, which served as the monumental entrance to the Temple
Terrace, was probably first constructed in the Classical period ( $5^{\text {th }}$ century B.C.), and was later repaired and rebuilt in the Hellenistic ( $3^{\text {rd }}$ century B.C.) and Roman Imperial ( $2^{\text {nd }}$ century A.D.) periods. As one Doric anta-block (of "type 1") is still preserved in situ at the SE façade of Propylon Y, we propose a reconstruction of this building as in the Doric order (the Doric columns of the eastern façade were, however, replaced by a Corinthian colonnade in the $2^{\text {nd }}$ century A.D. $)^{49}$. The stylobate on the eastern façade appears to have been completely replaced at this time. A number of architrave/frieze blocks were found during the excavations of Propylon Y in 1951. The date of the Roman phase of the building can be deduced from fragmentary architrave inscriptions and the outline of the architectural sculpture ${ }^{50}$.

The remains of a suggested Roman building, Stoa $\mathrm{B} / \mathrm{Y}$, still stand directly south and adjacent to Propylon Y (facing the Temple Terrace). The apparent function of this building was to seal off the narrow area between the Propylon and the south side of the Temple Terrace. To this we attribute the architraves of Lindblom's "type C", an Ionic capital, and a number of anta-blocks of "type 2" 51 . This short building presumably featured four Ionic columns in antis on its eastern façade. The column positions can be deduced from some preserved stylobate blocks in gneiss that show the dowel holes for the locations of the column bases. Despite its short length, the dimensions of all architectural members appear to correspond closely to other Roman buildings around the Temple Terrace, for instance the North Stoa.

48) $C f$. Hellström $2007:$ 95-7.

49) Hedlund 2014.

50) For the inscriptions, see Labraunda III:2.I : 24-26. For a stylistic survey on the Roman architectural sculpture of $2^{\text {nd }}$-century Labraunda, see Blid Kullberg $2014: 26-30$.

51) See Henry et al. $2013: 238$; Hedlund $2014: 66$. 


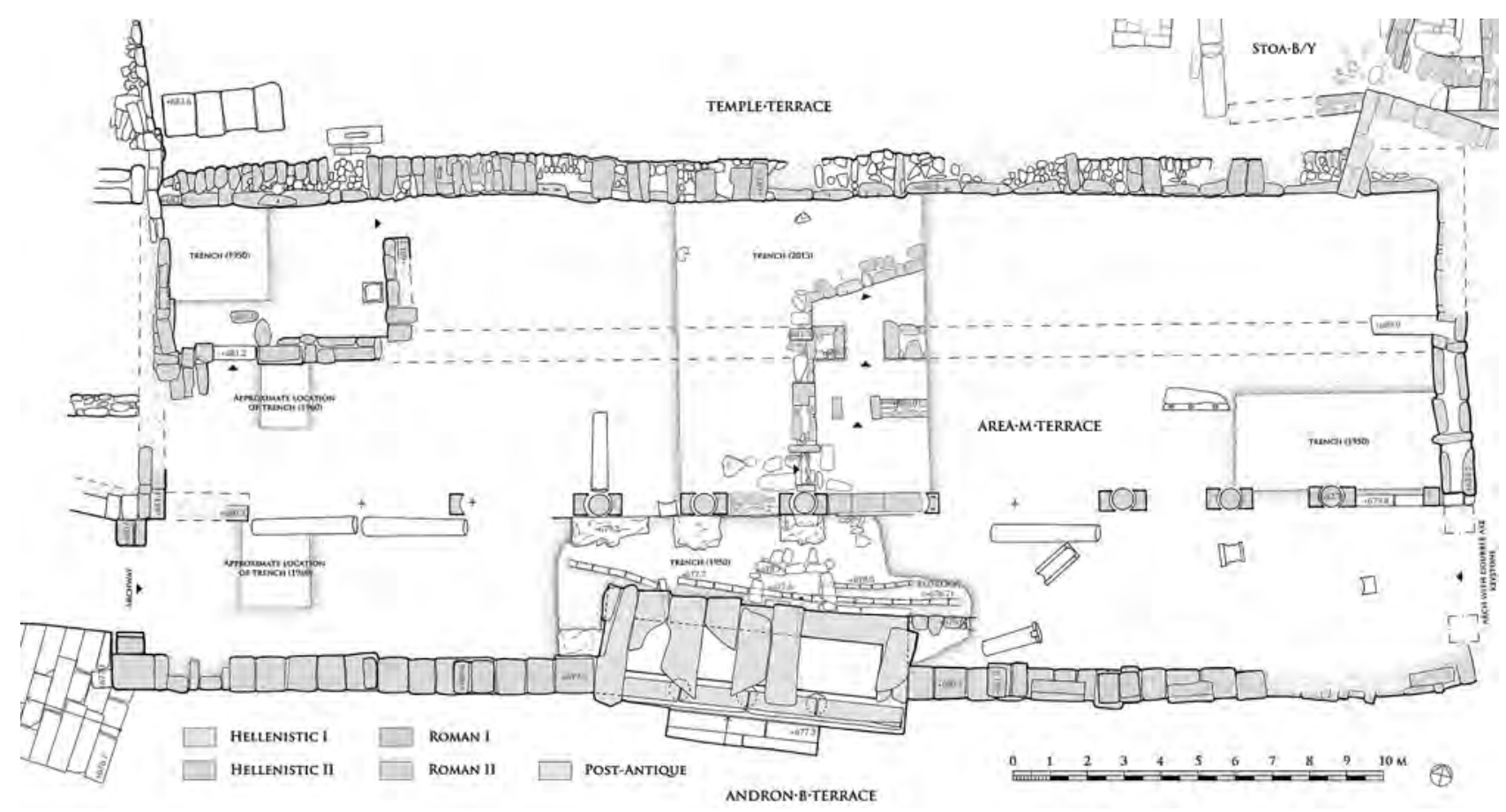

Fig. 68 : Actual state plan of Terrace M (J. Blid \& R. Hedlund).

\subsubsection{Excavations on Terrace $M$ (Fig. 68$)^{52}$}

The second part of the project was the excavation on Terrace M, which took place from $13 / 8$ to $28 / 8$. One $7 \times 8.5 \mathrm{~m}$ trench, M1, was opened at the very centre of Terrace M (Fig. 69). In total, the trench was excavated to a maximum depth of $c a .1 .5 \mathrm{~m}$, and five well-preserved strata (including two substrata of Str. 2 and 3) were unearthed (Fig. 70-71). Undisturbed strata are very unusual within the ancient temenos area owing to centuries of serious erosion and intense agriculture. Given that this year's excavations yielded several occupation phases, which have never been recorded before close to the Temple Terrace, we chose to save sections of every stratum, and thus a less destructive and more sustainable excavation methodology was conducted. This resulted in a series of deeper trenches which gave us very enlightening data in terms of chronology and function analysis, yet, perhaps, less understanding of the architectural remains of Terrace M. Nevertheless, the new discoveries of architectural features can be linked with documented remains of previous excavations, and still, in our opinion, offer solid evidence of the architectural development within the area.

This first preliminary report of the results of the 2013 excavations at Terrace M will only offer a small, general selection of finds presented in catalogues according to stratigraphy. We are still awaiting results from ${ }^{14} \mathrm{C}$ analyses and anthropological studies of the bone material. The final publication on the Hellenistic and Roman remains in the vicinity of the Temple Terrace is currently in the making, and this publication will present the full find sample from Trench M1.

\section{Stratum 1}

Initially, marble fragments and gneiss blocks on the surface were removed (Fig. 72). After this, the removal of a $c a .30-75 \mathrm{~cm}$ thick layer of topsoil, Str. 1, was begun (Fig. 73). The finds from the topsoil comprise of fragmentary ceramics, roof tiles, and several remains of sculptured- and plain wall revetments cut from various marbles. Most of these fragments can be stylistically dated to the Roman Imperial period. The pottery sample of this disturbed layer mainly consists of Byzantine and Ottoman glazed wares of which a selection will be schematically presented below (the processing of this material is currently in progress). The numerous fragments of medieval, glazed fine wares are especially interesting as these clearly indicate the presence of settlements in the sanctuary even in the Byzantine period. This is something that has not been recorded before in the direct vicinity of the Temple Terrace, even 


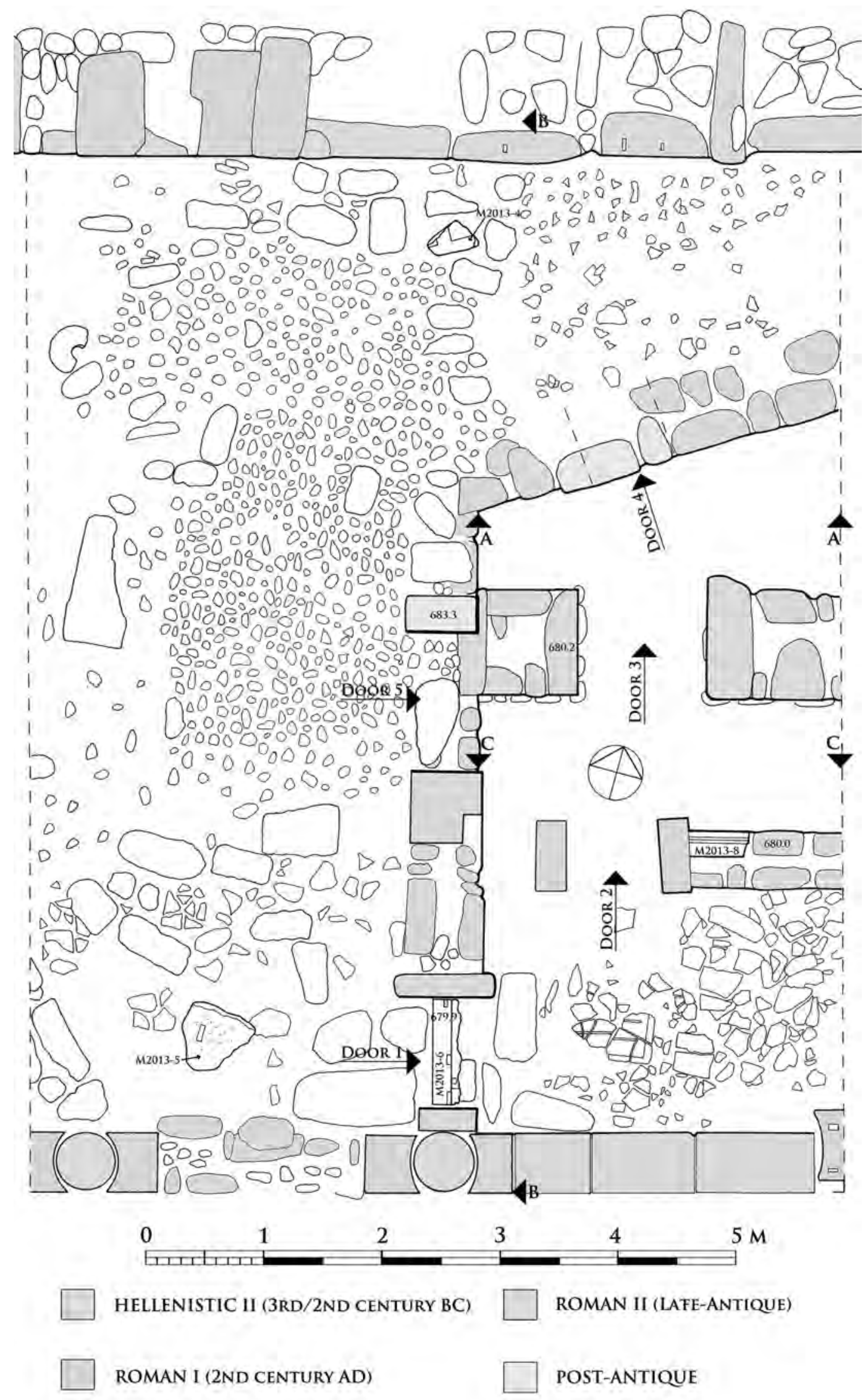

Fig. 69 : Actual state plan of Trench M1 (J. Blid \& R. Hedlund). 


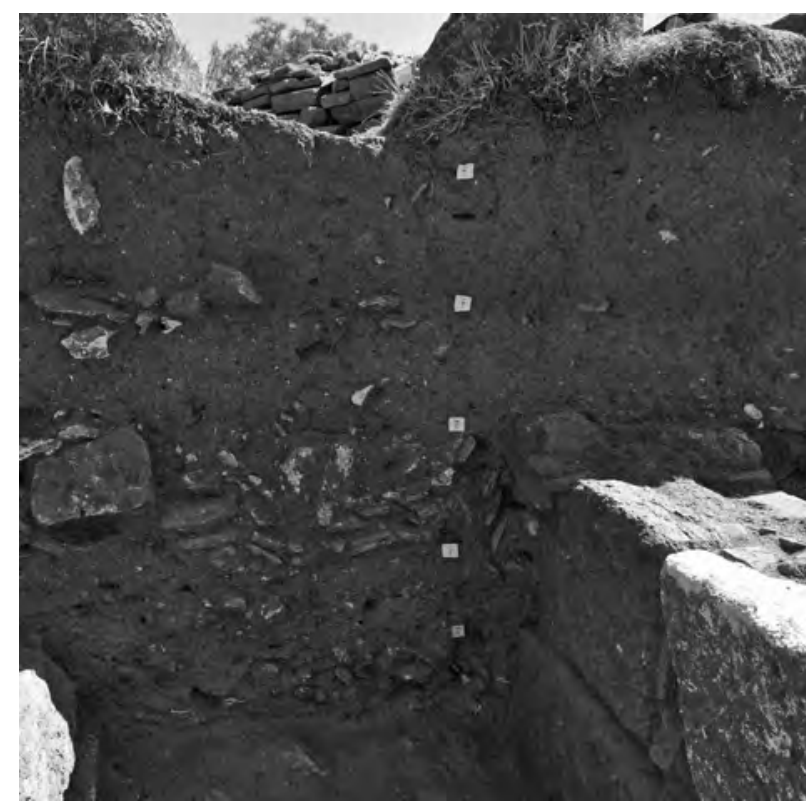

Fig. 70 : Strata shown in the eastern section of Trench M1 (J. Blid \& R. Hedlund).

though a varying degree of Byzantine activities have previously been documented at the Tetraconch, the West Church Complex, the East Church Complex, Andron C, the western annex of Andron B, and inside the Akropolis fortress ${ }^{53}$. Also, the occurrence of Ottoman pottery is exiting news at Labraunda as nothing from this period has ever been published at the site.

It seems that the dwelling of Str. 1 was entered from Door 5 (see fig. 69). It should, however, be noted that this may originally have been a window of the subsequent structure associated with Str. 3 \& 3B. Nothing else remains of the architecture that may have been associated with Str. 1 .

\section{Stratum 2}

Below the topsoil, in the middle of the upper 2 $\mathrm{m}$-sector of the trench, we unearthed a second stratum: a layer of small and medium sized stones, roof tiles, and several fragments of decorated marbles. Possibly, the many marble fragments indicate that a lime-kiln was present somewhere in the close vicinity. The marble fragments (mainly wall revetments) seem to be Roman in date and most probably they belong to the $2^{\text {nd }}$ century A.D. superstructure of Building M. Among these fragments are Corinthian pilaster capitals, egg-and-dart mouldings, and lotusand-palmette friezes. The ceramic finds included fragments of a vast chronological sample of roof tiles (presumably Hekatomnid, Hellenistic, Roman, and late Roman). Among the pottery, the most easily distinguishable material is Phocaean Red Slip ware of the late $5^{\text {th }}$ to mid- $6^{\text {th }}$ century A.D., of which several fragments were recorded.

The configuration of Str. 2 can only be interpreted as a collapsed layer of one or several walls and their superposed roof. Yet, the configuration of the collapse may help us to reconstruct a long-term decay rather than a swift destruction. The roof tiles were found under the stones and, therefore, the roof collapsed first and was finally covered by the crumbling walls; thus, this was presumably a slow process of decay. The collapsed roof and walls of the early-medieval building complex covered the substratum, Str. 2B, which is the actual occupation phase. The upper elevation of the walls are not very well preserved and it is therefore difficult to comment further on the architectural disposition of the early-medieval phase (however, see the discussion below on the general, architectural development within the trench).

\section{Strata $3 \& 3 B$}

The architectural remains of an earlier building complex emerged below Str. $2 \& 2 B$. This partly protruded from the superposed occupation layers directly above. In fact, these remains actually constituted the foundations of the later occupation phase of Str. $2 \& 2 B$. The walls associated with Str. $3 \&$ 3B had been subdued by little alteration during the Middle Ages. Most notably, Door 4 was paved up; yet, apart from this, no new walls had been added, aside from the previously mentioned Door 5 , which, in fact, may be a window from the Str. $3 \& 3 \mathrm{~B}$ phase ( $c f$. Section B-B; Fig. 74).

The occupation of the Str. $3 \& 3 \mathrm{~B}$ can be dated from both numismatic and ceramic evidence, which will be further shown in the catalogue below. Next to Door 1, directly on the exact same level as the threshold, a bronze coin of Constantine 1, dated to A.D. 323-324, was unearthed. This coin marks the terminus post quem for the occupation phase. Furthermore, the ceramic data shows clear activity during the $5^{\text {th }}$ century. Both coarse, cooking wares, and fine wares are represented within the sample. It seems that the construction of this late-antique building complex should be placed in the 'renaissance' of the site during the rule of the House of Constantine, which has previously been highlighted ${ }^{54}$. There is

53) Cf. Blid 2012 : 38, 82, 89, 142-143, 158-159, 222, 239-242; Karlsson $2010: 67-74$. Some Byzantine pottery and glass have also been published by Hellström; $c f$. Labraunda II: 1 .

54) Cf. Blid $2012: 252,254$. 

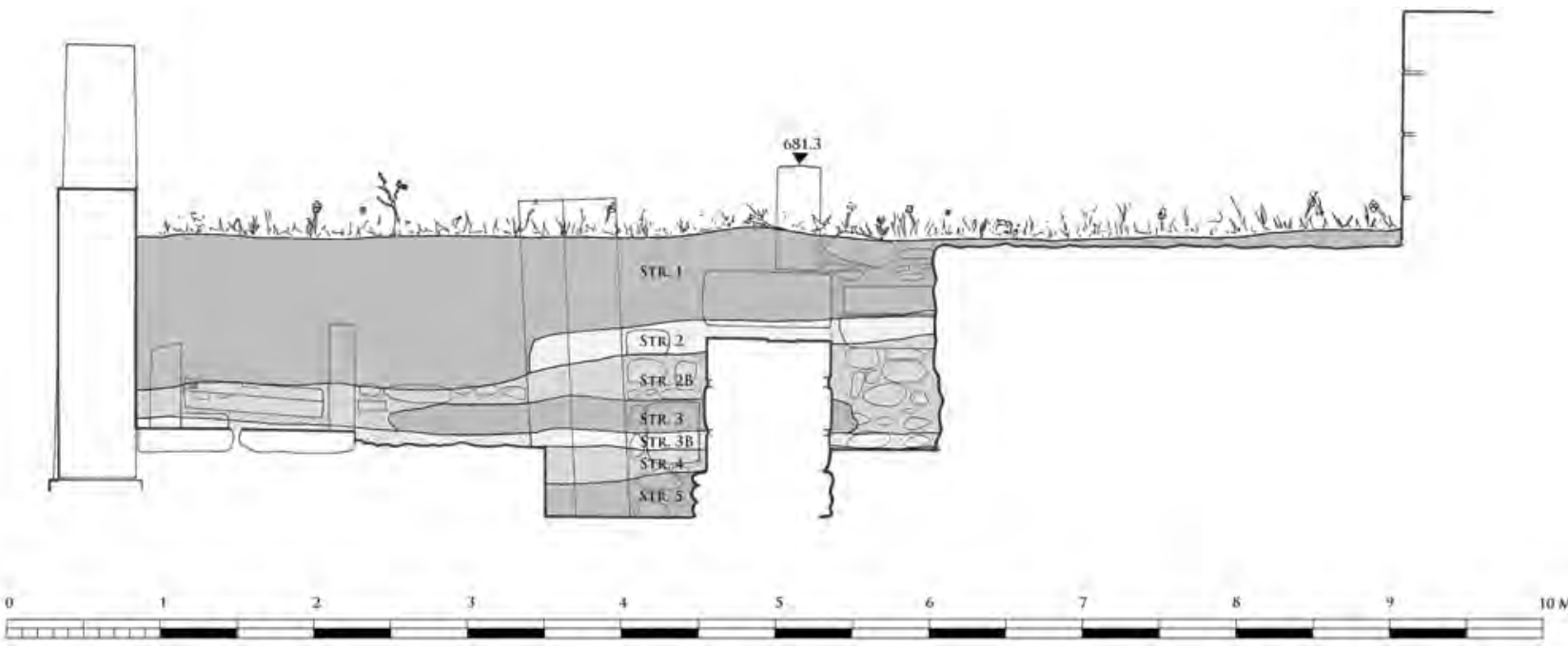

Fig. 71 : Section B-B with added stratigraphical references (J. Blid \& R. Hedlund).

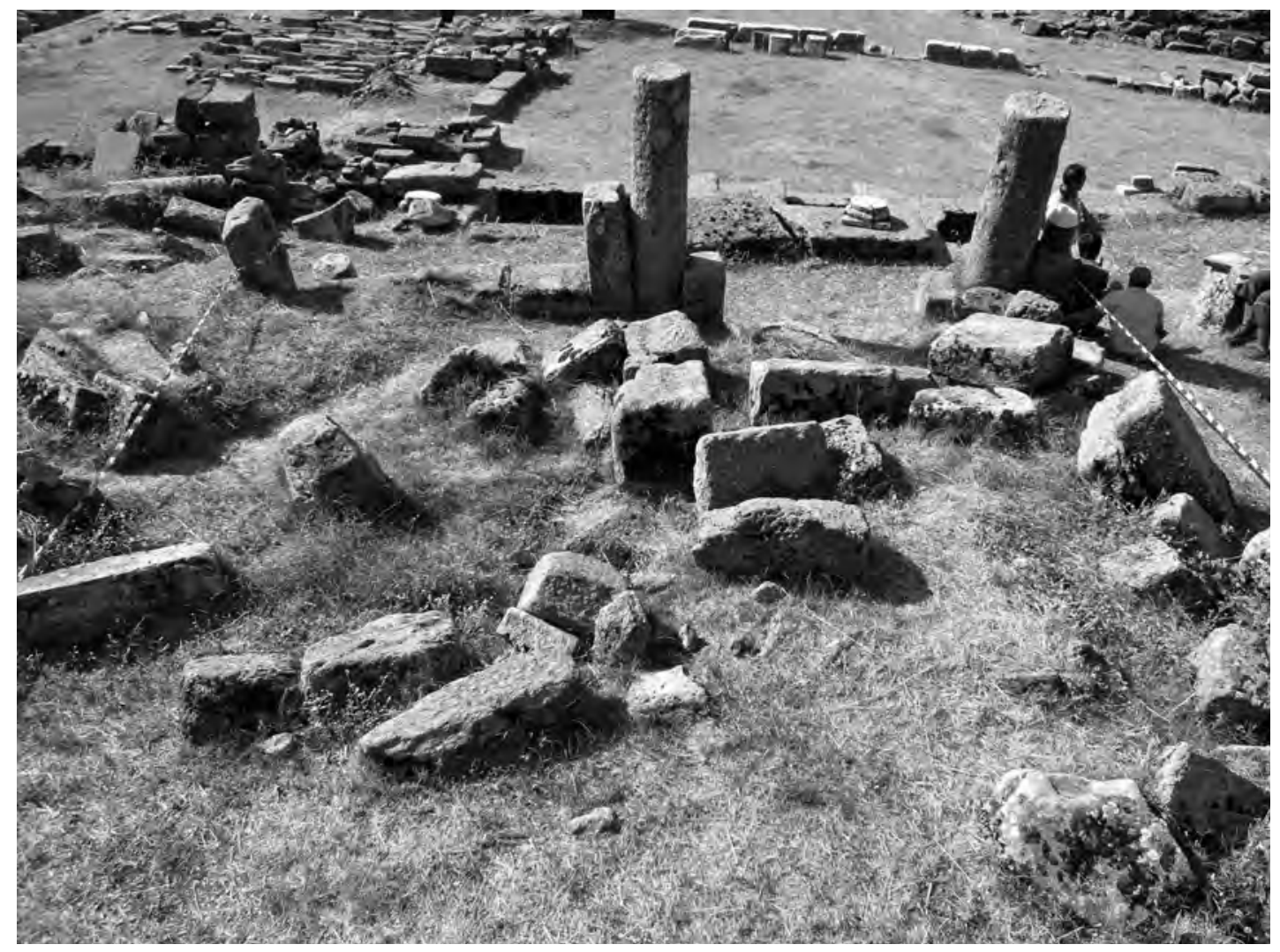

Fig. 72 : The area of Trench M1 before the excavation (J. Blid \& R. Hedlund). 


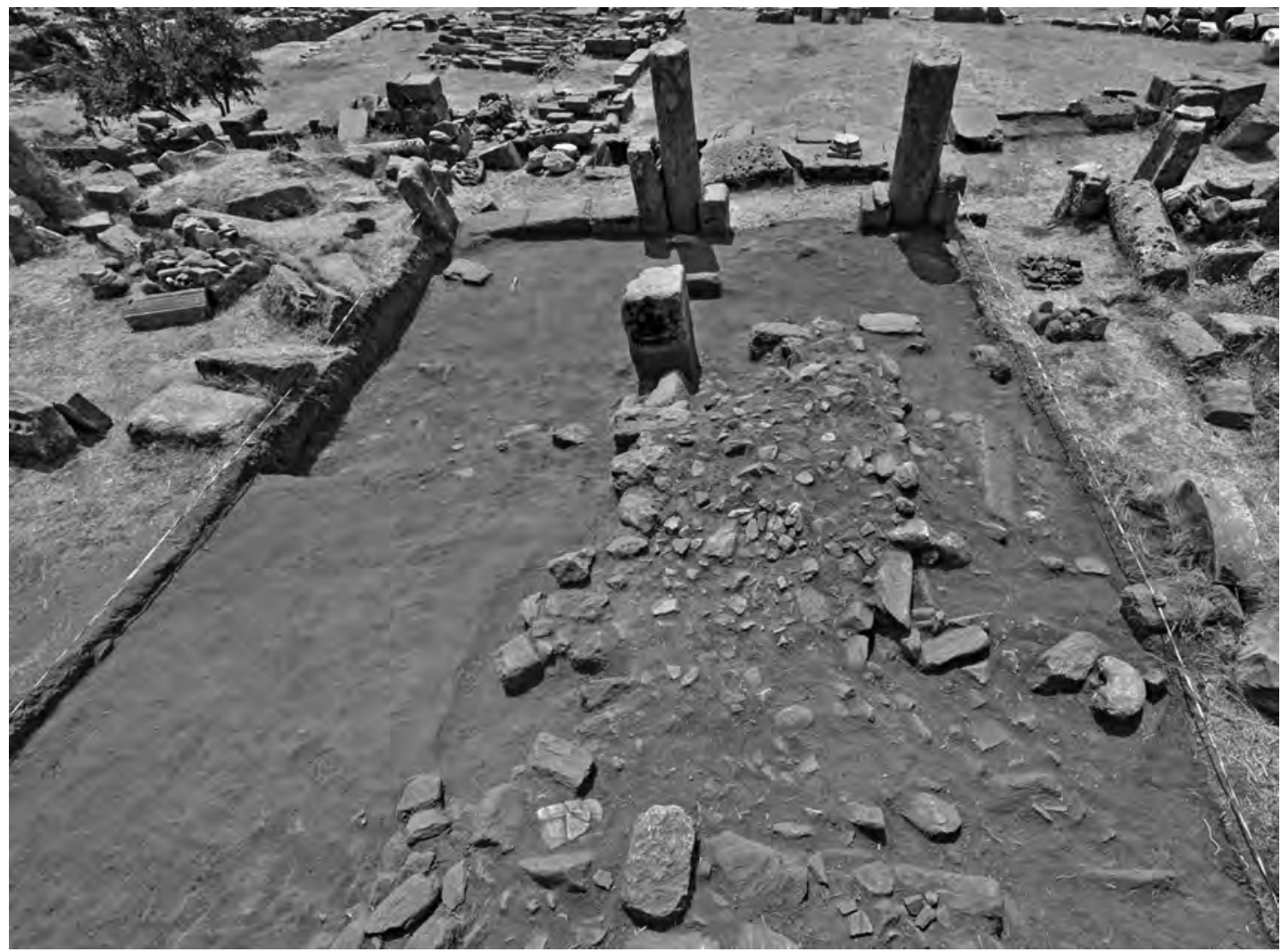

Fig. 73 : Trench M1 after the removal of the topsoil (J. Blid \& R. Hedlund).

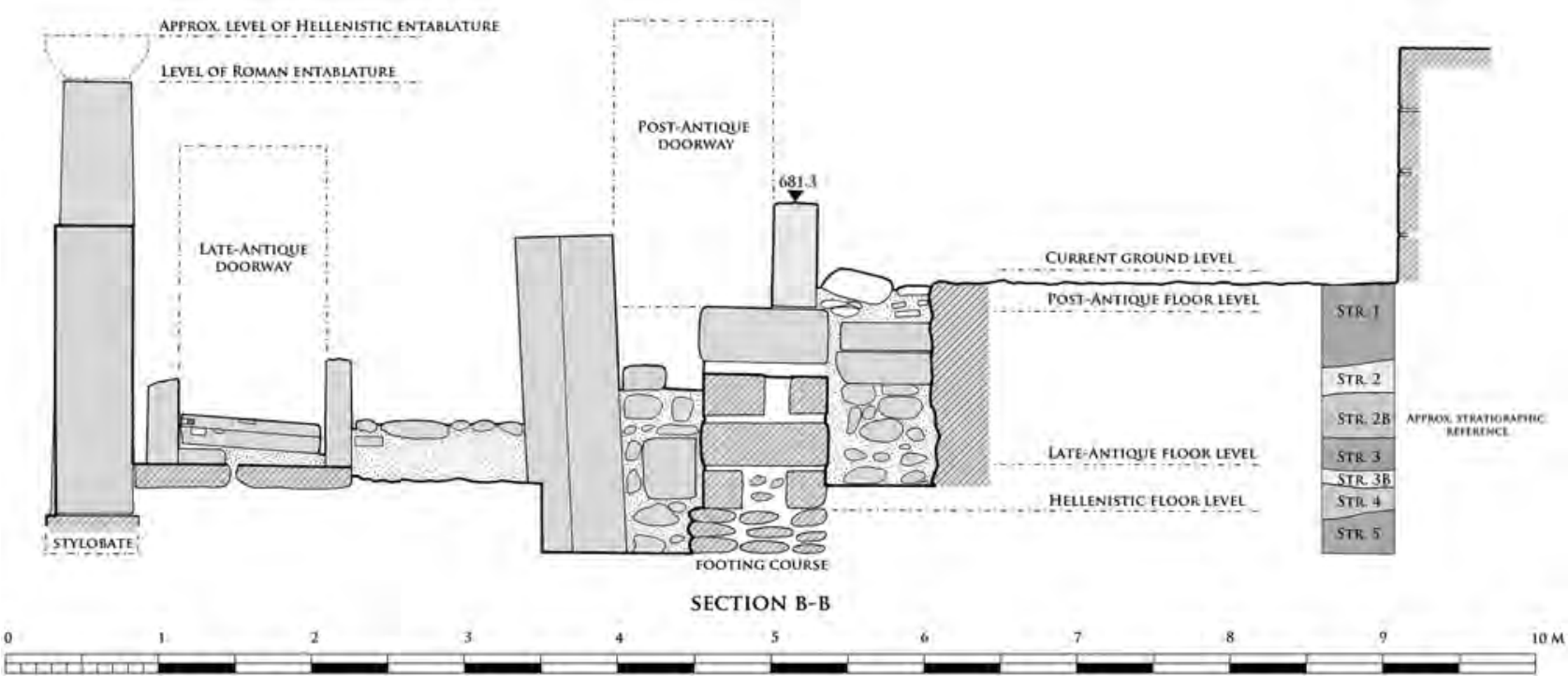

Fig. 74 : Section B-B displaying the standing architectural remains with chronological references (J. Blid \& R. Hedlund). 
really no evidence to suggest that this phase was in use later than the late $5^{\text {th }}$ century A.D.

The walls related to Str. $3 \&$ B B were constructed by reused gneiss and marble blocks. Door-posts are most often built by gneiss stylobate blocks, presumably originating in the Roman-imperial phase of Building M. These blocks can easily be distinguished by their standardized dimensions and round dowel holes used for the attachment of the columns. Similar examples can still be seen in situ, for instance at the adjacent Stoa B/Y (see above) $)^{55}$.

In the SW part of the trench, we find what seems to be the main entrance of the late-antique complex, Door 1. The threshold is made from a reused marble block exhibiting clear remains of clamp holes (Fig. 75). To the west of this doorway are the remains of a marble pavement, also made from marble spolia. This area may have been an open courtyard in front of Door 1. Above the marble pavement of the courtyard, a layer of $c a .0 .15 \mathrm{~m}$ fragments of roof tiles, smaller stones, and marble fragments (collapse layer) were removed. To the east of the threshold, very few finds were found on the equivalent level; those that were found were mostly roof tiles.

The destruction layer, Str. 3, is a closed deposit of large roof tile fragments which have fallen (preserved in the original collapse position), and secondarily been covered by building material (marble and gneiss) coming from the surrounding walls. On this level in the central parts of the trench, there were also traces of blackened soil, which we interpret as the decomposed remnants of the wooden features of the roof. This hard, compressed layer of roof tiles and stones later constituted the perfect foundation for the medieval occupation phase recorded above. Like Str. $2 \& 2 B$, Str. 3 is a destruction layer covering the actual occupation layer, Str. 3B. The perfectly preserved, closed deposit of Str. $3 \& 3 B$ gives us an opportunity to date certain materials from stratigraphic excavation, which previously has been unmanageable at the site of Labraunda. The fallen roof tiles of Str. 3 are rather different from the late-antique, Laconic type previously recorded at the Tetraconch and West Church ${ }^{56}$.

The tiles from Str. 3 are slightly curved and measure about $74 \times 48 \mathrm{~cm}$, which makes them among the largest roof tiles ever recorded at the sanctuary. Since this type is not represented in any of the late-antique churches (which presumably date from the early $5^{\text {th }}$ century onwards), and they must predate the Phocaean Red Slip ware found in the layers above, this roof tile type is presumably from the original phase of the late-antique construction, thus dating to the first half of the $4^{\text {th }}$ century A.D.

The late-antique occupation noted in Str. 3 \& 3B comprise at least two rooms and the presumed anterior open courtyard in the SW sector. There also seems to be a passageway (Door 4) connecting the northern room to an oblique corridor in the northernmost part of the trench. In the centre of Trench $\mathrm{M} 1$, an east-west-oriented wall, built with reused materials, including the marble block M2013-8 (see fig. 69), was found (seen to the left in fig. 76). This block also shows remains of clamp cuttings, and, like the threshold M2013-6, it was probably reused from the epistyle of the A.D. $2^{\text {nd }}$-century phase of Building M (another such block is M2013-5, which was found in the centre of the open courtyard in the $\mathrm{SW}$ sector of the trench). There is a doorway in the centre of the late-antique wall (Door 2), which gave access to the inner area of the complex.

\section{Stratum 4}

A thin, $c a .10-20 \mathrm{~cm}$ layer (Str. 4), located under the late-antique Str. 3B, comprised a vast variety of both organic and ceramic material, which can be ascribed to the late Hellenistic and Roman Imperial period (the material seems to be rather mixed up). Remains of a Hellenistic or Roman mortar floor were also found at this level.

In the central sector, exactly halfway between the southern gneiss colonnade and the northern terrace wall, we were able to confirm our hypothesis of an east-west-oriented wall, belonging to the original, Hellenistic phase of Building $M$ (which was a 35.6-36.5 m long and 14.2-14.7 m wide Doric stoa facing the south). The wall is similar to the back wall of the complex: built by a two-skinned emplekton wall with gneiss ashlars (Fig. 77). The wall is equipped with a doorway, Door 3 , which corresponds exactly with the intercolumnation of the gneiss colonnade further to the south. This shows that the Hellenistic stoa was divided into an outer colonnade and a closed off inner section, which could be sealed with a door (from which the iron handle M2013-MT009-2 may originate). It seems, however, that the inner section was a continuous corridor rather than a series of small, square rooms, like, for example, in the late-Classical stoai of Labraunda $^{57}$. Remains of mortar on the rough gneiss

55) $C f$. Hedlund $2014: 67$ (Fig. 3).

56) Blid $2012: 53-54,124-125$.

57) $C f$. the East Stoa and the stoa of the earliest phase of the West Church. 

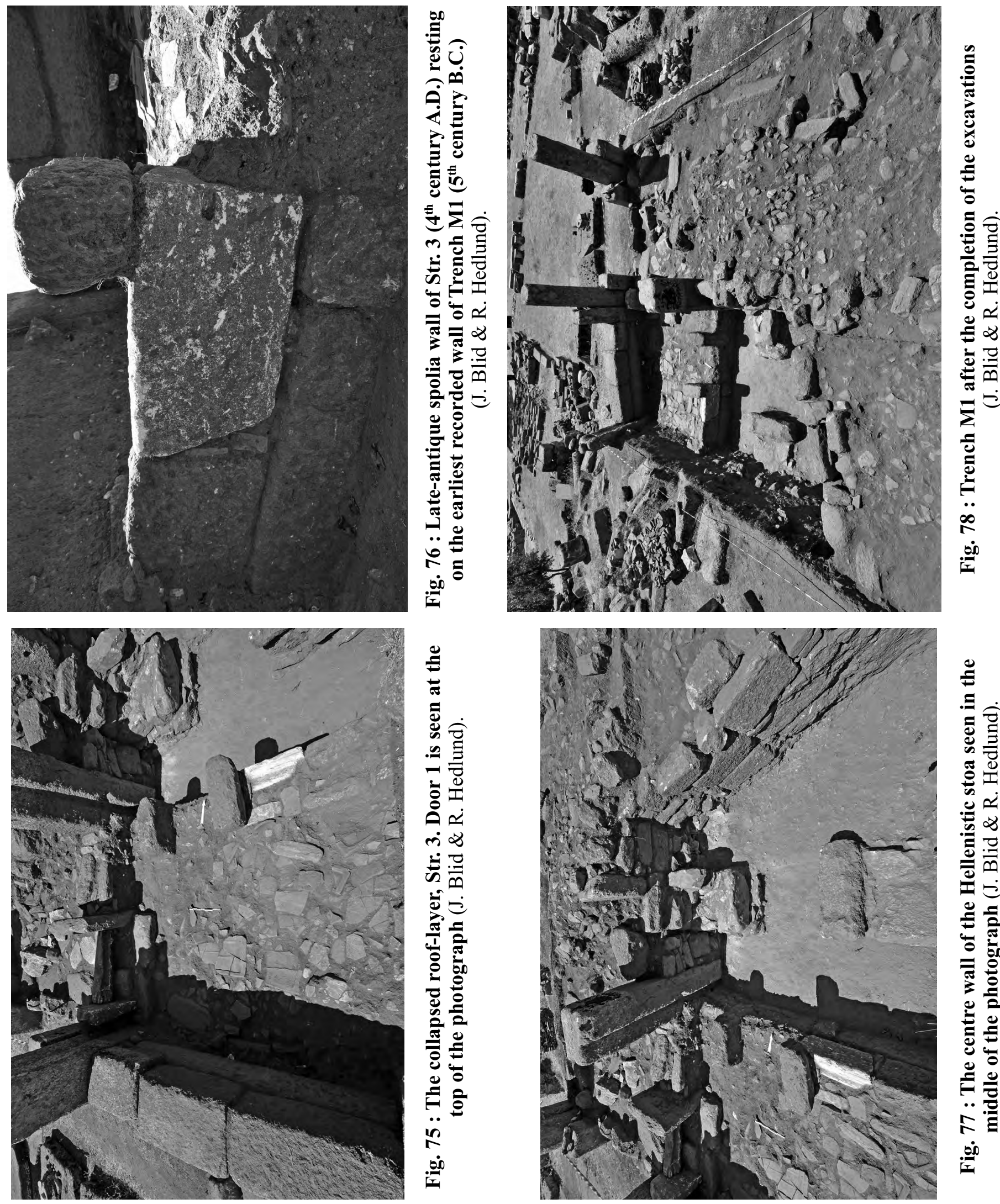

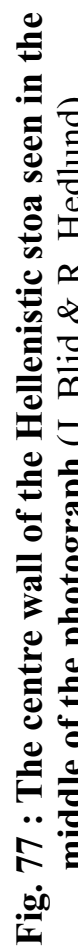


centre wall also indicate that its surface was smoothened with stucco. Given that the mortar remains were found also on the top section of the footing course (which, presumably, would have been slightly buried in the Roman period), we suggest that the treatment of the gneiss façade may be original Hellenistic.

\section{Stratum 5}

At the level of the footing course of the Hellenistic centre wall (Str. 5), a large number of ceramic finds were retrieved. For instance, two bowls of the socalled Achaemenid type and a Koan amphora, which, according to our ceramologist, Vasilica Lungu, should be dated to the mid- $3^{\text {rd }}$ century B.C., thus giving us a date for the Hellenistic construction. In fact, this seems to be the date of most pottery coming from the level of the footing course. The earth was somewhat different from superposed layers as it consisted of reddish, sandy soil. There were no stones or roof tiles in this layer. As the layer connected with the footing course primarily contained many fragments of bone, and the ceramic sample mainly consisted of table wares, like table amphorae, hydriai, pitchers, craters, and lots of so-called 'fish plates', along with storage vessels like amphorae and pithoi, it is probable that, in its original, Hellenistic phase, Building $\mathrm{M}$ was used as a banqueting stoa. The remains of bones (which are currently being studied) and pottery could, therefore, reflect this utility.

At the very bottom of Str. 5, we encountered a transitional stratum (which was only investigated at the very top, and likely represents a separate, preHellenistic phase). This layer was likely a fill coming from the foundation trench made in the $3^{\text {rd }}$ century for the construction of the Hellenistic centre wall. Thus, this material was already here when the construction of the Stoa begun. The material includes fine wares, for instance a black-gloss bowl and a figurine (probably a hydrophoros) of the $5^{\text {th }}$ century B.C. There is also an architectural structure that can be related to these finds. The previously-addressed late-antique wall, which includes the reused marble block M2013-8 (see Fig. 76-77), and runs parallel to the Hellenistic centre wall, is founded upon an earlier gneiss wall, which, without doubt, predates the Hellenistic wall further to the north (there are, for instance, no visible foundation trenches for this wall seen in the section, see Fig. 70). This means that it cannot have been built after the construction of the Hellenistic centre wall. Furthermore, its foundations are on a deeper level. Since only a fraction of this wall has been unearthed, it is not possible at the moment to conclude what kind of building this would be or how vast it is. We can simply determine that Building $\mathrm{M}$ was preceded at this site by at least two previous buildings: the early Hellenistic (?) fountain house to the south and this, currently unexplored, $5^{\text {th }}$-century building.

\section{Architectural analysis and chronological development}

The Terrace M excavations of 2013 support our previous interpretation that Building $\mathrm{M}$ was originally built as a two-aisled stoa in the Hellenistic period (Str. 5, Fig. 78, see also Fig. 74). Yet, there were older, Classical walls (probably $5^{\text {th }}$ century) of unknown condition on site at that time. The Doric two-aisled stoa, which was probably built in the $3^{\text {rd }}$ century B.C., may have been used for banqueting and storage of wine and foods, as suggested by organic and ceramic evidence. Building $M$ was undoubtedly one of the largest buildings within the temenos at this time, also incorporating the Wellhouse on the Andron B Terrace further to the south (see Fig. 67-68). Str. 5 also exhibits the largest quantities of pottery, which, in our opinion, pinpoints the importance and vast activity at this particular terrace in the Hellenistic period.

The late-Hellenistic and Roman-imperial (mainly $1^{\text {st }}$ century B.C. to $2^{\text {nd }}$ century A.D.) layer situated directly atop of the footing course of the Hellenistic centre wall indicates continuous activity. We link the Roman fine wares, like the so-called Knidian thin walled ware, to the restructuring of Building $\mathrm{M}$ in the $2^{\text {nd }}$ century A.D. (Str. 4). From a survey of Roman architectural remains found in the area, we have already suggested that Building $\mathrm{M}$ was given a new upper storey, mostly in marble, in the style of the North Stoa. Nevertheless, it seems evident that the daring and poorly built imperial phase of Building $\mathrm{M}$ did not last long, as the area appears to have become reoccupied by completely different structures in the Constantinian period. Some $2^{\text {nd }}$-century adjustments to the Hellenistic architecture of Building $\mathrm{M}$ were to remove the capitals of the gneiss colonnade, replace the (presumably) wooden superstructure with a lower stone architrave with sockets for wooden beams (which have been identified on Terrace M), and consolidate the gneiss columns with partly doweled supports so as to transform them into studier piers (Fig. 79). The fragments of marble revetments found in Strata $2 \& 2 B$ may give us an idea of the interior decoration of Building $\mathrm{M}$ in the Roman period (these remains most probably originate from the collapsed superstructure in the 


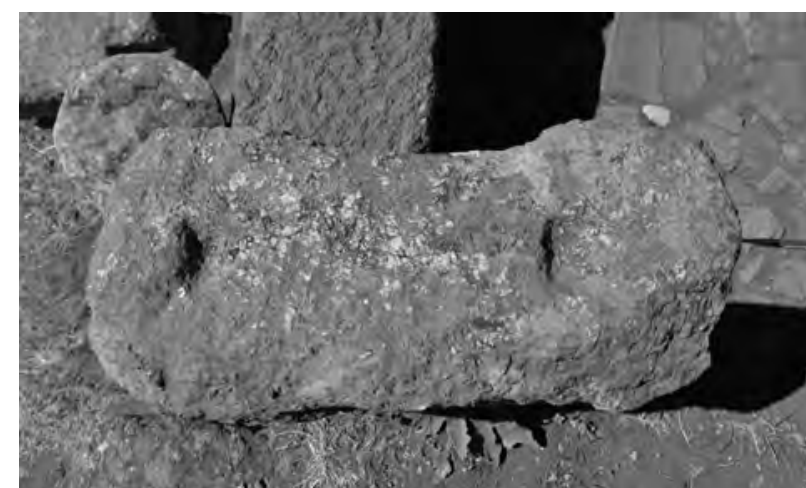

Fig. 79 : Upper side of Roman gneiss supports (with dowel holes) used to consolidate the Hellenistic colonnade at the construction of the $2^{\text {nd }}$-century A.D. superstructure (J. Blid \& R. Hedlund).

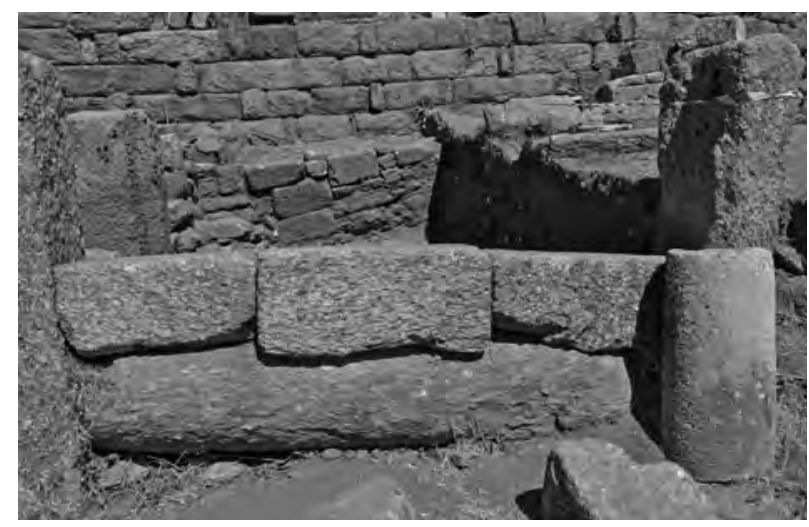

Fig. 80 : Late-antique wall made from blocking the intercolumnation of the Hellenistic (and Roman Imperial) phase of Building $M$ (J. Blid \& R. Hedlund).

level of the Temple Terrace). The interiors apparently were decorated with Corinthian pilasters and wall panels separated by egg-and-dart mouldings and lotus-and-palmette friezes.

The first reoccupation after the collapse of the $2^{\text {nd }}$-century phase of Building M may be dated to the first quarter of the $4^{\text {th }}$ century (Str. $3 \& 3 B$ ), and this resulted in the blocking of the intercolumniations of the Hellenistic portico of the stoa (Fig. 80), and the construction of small, oblique rooms attached to corridors and, presumably, an open courtyard. Most probably, the whole of Terrace $M$ was occupied by similar constructions at this time since an almost identical architectural unit was unearthed in the NW corner of the terrace in 1950 and 1960. It is hard to tell if the late-antique reconstruction of Building $\mathrm{M}$ was still used for ritual feasting. However, large quantities of cooking and fine table wares may favour this interpretation. Perhaps this was another part of the last revival of organized polytheistic cults in the first half of the $4^{\text {th }}$ century, which has previously been suggested for other areas of the sanctuary. If so, Building $\mathrm{M}$ was part of the same architectural trend that spawned the Tetraconch, the South Bath, and the increased activity at Andron C. The $4^{\text {th }}$ - and $5^{\text {th }}$-century phase was followed by a (presumably) $6^{\text {th }}$-century occupation (Str. 2), which reused the earlier building complex, but apparently rebuilt the walls and added a new tile roof with older, reused roof tiles. After the late antique period, there were several following occupation phases, both of Byzantine and Ottoman date. These occupations have left few architectural remains but a relatively substantial body of ceramic evidence (Str. 1).

The excavations on Terrace $\mathrm{M}$, and the architectural survey on the Temple Terrace and Terrace Y, together provide an insight into the building politics of Labraunda in the Hellenistic and Roman Imperial periods. The buildings on the eastern side of the Temple Terrace seem to have been built, or at least rebuilt, in the $2^{\text {nd }}$ century A.D., partly with material that was recycled in a rather ad hoc fashion. A far more ambitious project, the monumental colonnaded hall, Building M, was also constructed in a haphazard way, which ultimately led to a collapse of the building. The current epigraphic and archaeological evidence from the addressed buildings of the Imperial age suggests that Labraunda was a locus where it was important for local priests to dedicate monumental buildings of a spectacular fashion, even if the foundations were literally crumbling under their marble decorations.

\subsection{The Hypostyle Building (par Felipe Rojas ${ }^{58}$ Linda Gosner, Andrew Dufton, and Andrew Waters $)^{59}$}

During the summer of 2013, a Brown University team led by Felipe Rojas partially excavated and

58) Joukowsky Institute for Archaeology and the Study of the Ancient World, Brown University, Providence, RI, USA. E-mail: felipe_rojas@brown.edu

59) We would like to express our gratitude to the Turkish Ministry of Culture and Tourism as well as to the Milas Archaeological Museum and its director for the opportunity to work in Turkey. We would also like to thank the director of the Labraunda project, Dr. Olivier Can Henry, for the invitation to work at Labraunda and for his patience throughout the season, as well as our fellow team members: Laura Leddy, Christina DiFabio, Hilal Küntüz and Marco Ziff. We also extend our gratitude to our Turkish, Swedish, and 


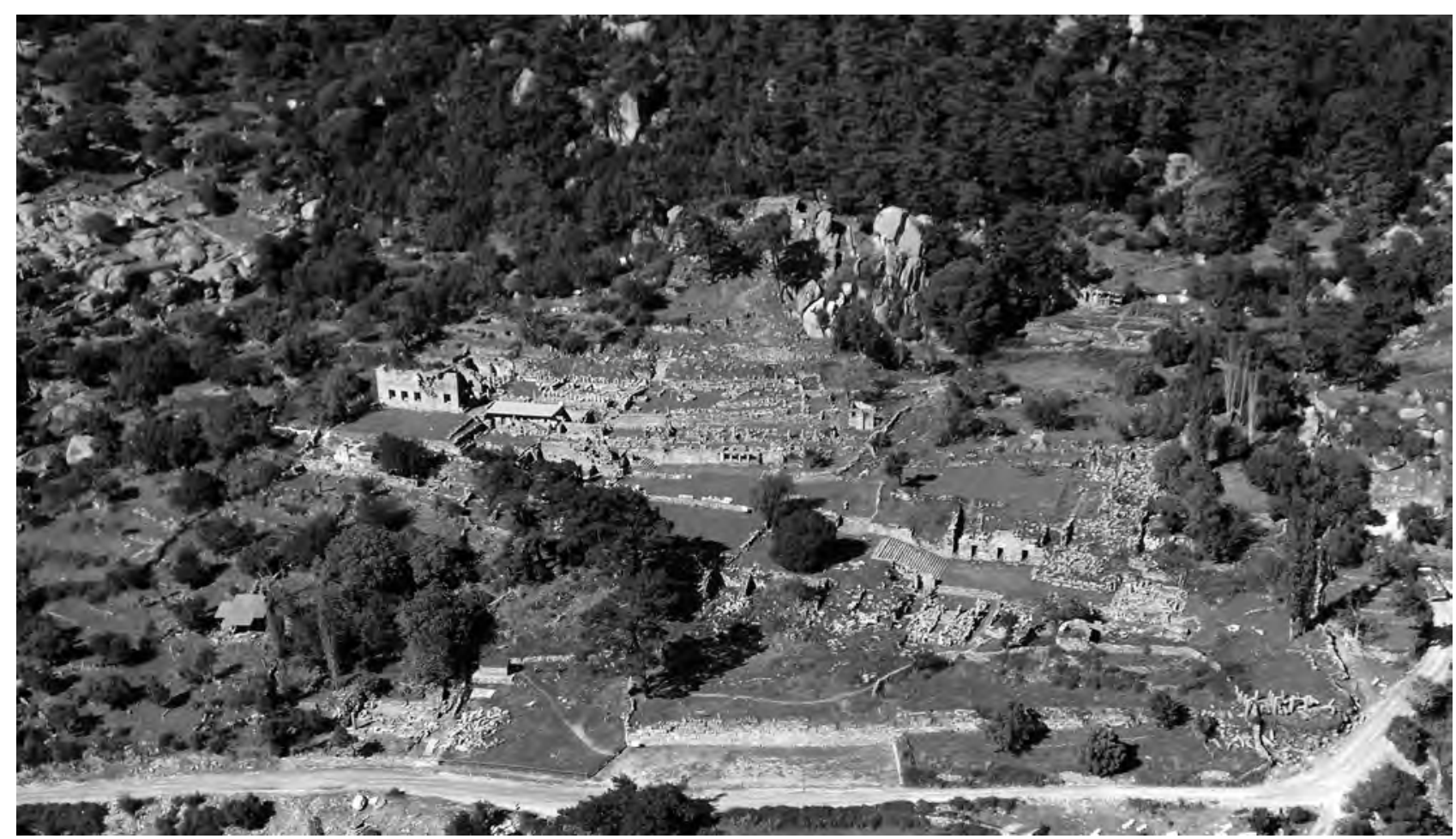

Fig. 81 : Aerial view of the sanctuary, HB is located on bottom right of the photo

(photo: Milas Museum).

documented the so-called Hypostyle Building (hereafter $\mathbf{H B}$ ) at the SE end of the ancient sanctuary of Labraunda in Karia (Fig. 81). The project's main research objectives were to elucidate the date and function of the monument, as well as to analyze the architectural design and building process of what was arguably Labraunda's largest and most conspicuous fountain house. This document provides a brief architectural description of the monument, an overview of the history of research, and an account of the 2013 excavation season. A detailed architectural study will be published after we complete the excavation of the building.

\subsubsection{General Architectural Description}

The HB is a monumental fountain house at the SE end of the sanctuary of Labraunda. Preliminary analysis suggests that its construction dates roughly to the Hellenistic period (somewhere between the mid $4^{\text {th }}$ and the early $2^{\text {nd }}$ century B.C.); the monument is certainly no earlier than the $5^{\text {th }}$ c. B.C. and no later than the $1^{\text {st }}$ century A.D.
The HB is made entirely out of gneiss (covered partly in hydraulic plaster and tile). As exposed until now, it is approximately $20 \mathrm{~m}$ long by $7.5 \mathrm{~m}$ wide (Fig. 81-87); since the structure's foundation is partly disarticulated and much of it still lies buried, more precise measurements will have to wait until the whole monument is excavated.

The fountain is composed of at least three rows of seven (or, less probably, nine) columns (see Fig. $83,85-87$ ). The column capitals are Doric, but the building does not conform to canonical classical architecture. The $\mathrm{N}$ façade of the $\mathbf{H B}$ flanks a narrow porch bound on the $\mathrm{S}$ by a low $(0.55 \mathrm{~m})$ parapet. On the parapet stands a second row of columns. The back of the parapet served as the wall of a large water basin that extended E-W probably for the full length of the building. A third row of columns stood in the water basin; we hypothesize that a fourth row of columns or a wall stood atop the $\mathrm{S}$ wall of the basin. The entire $\mathrm{S}$ side of the monument awaits further investigation since it currently lies under block tumble. The basin walls and at least those columns that stood in the water (row C) were 


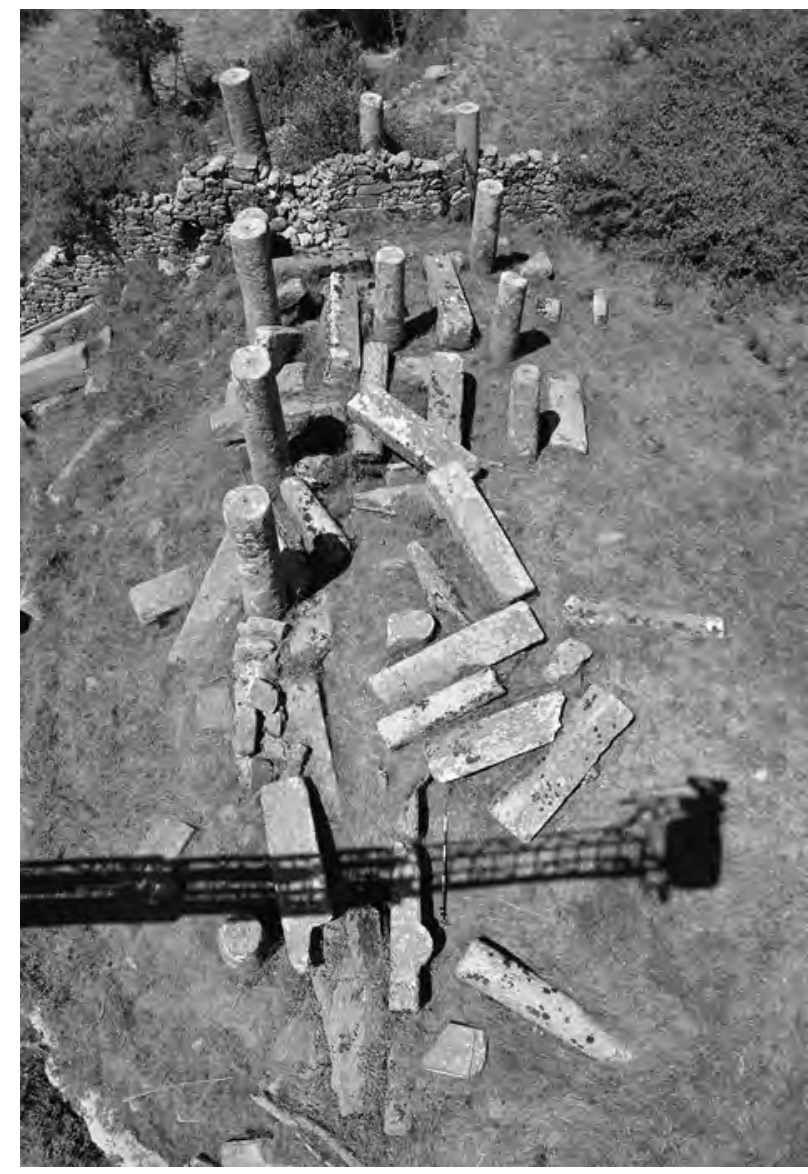

Fig. 82 : Aerial view of HB prior to excavation looking roughly $\mathrm{SW}$ along axis of $\mathrm{HB}$ (photo: O. Henry). plastered and re-plastered several times with successive layers of hydraulic mortar (see infra section 4.4.3., Trench B). People would certainly have been able to access the HB's waters from the $\mathrm{N}$ and perhaps also from the $\mathrm{S}$ of the building, in which case we should expect to find a second lower basin under the tumble.

From an architectural perspective, the HB's massive stone roof is specially interesting and peculiar. The gently pitched roof is covered by stone slabs that are as long as $3.10 \mathrm{~m}$ and can weigh up to 1.5 tons (see Fig. 84). The profiles of these slabs seem to imitate ceramic pan and cover tiles, but the blocks effectively act as a combination of tiles and rafters. These slabs are in some ways reminiscent of other massive stone tiles in Karia such as those found in the so-called 'temple' at Gerga.

Regardless of its exact date, the $\mathbf{H B}$ has the potential to shed light not only on the history of monumentalization of Labraunda, and the practicalities of pilgrimage in the sanctuary, but also on vernacular traditions of monumental architecture in Western Asia Minor. Even today, the HB is an imposing monument; it must have been all the more impressive when the entire hypostyle building was erect, the gneiss structure was probably whitewashed or plastered, and pilgrims from all over Karia flocked to the monument to enjoy the sacred waters of Zeus Labraundos.

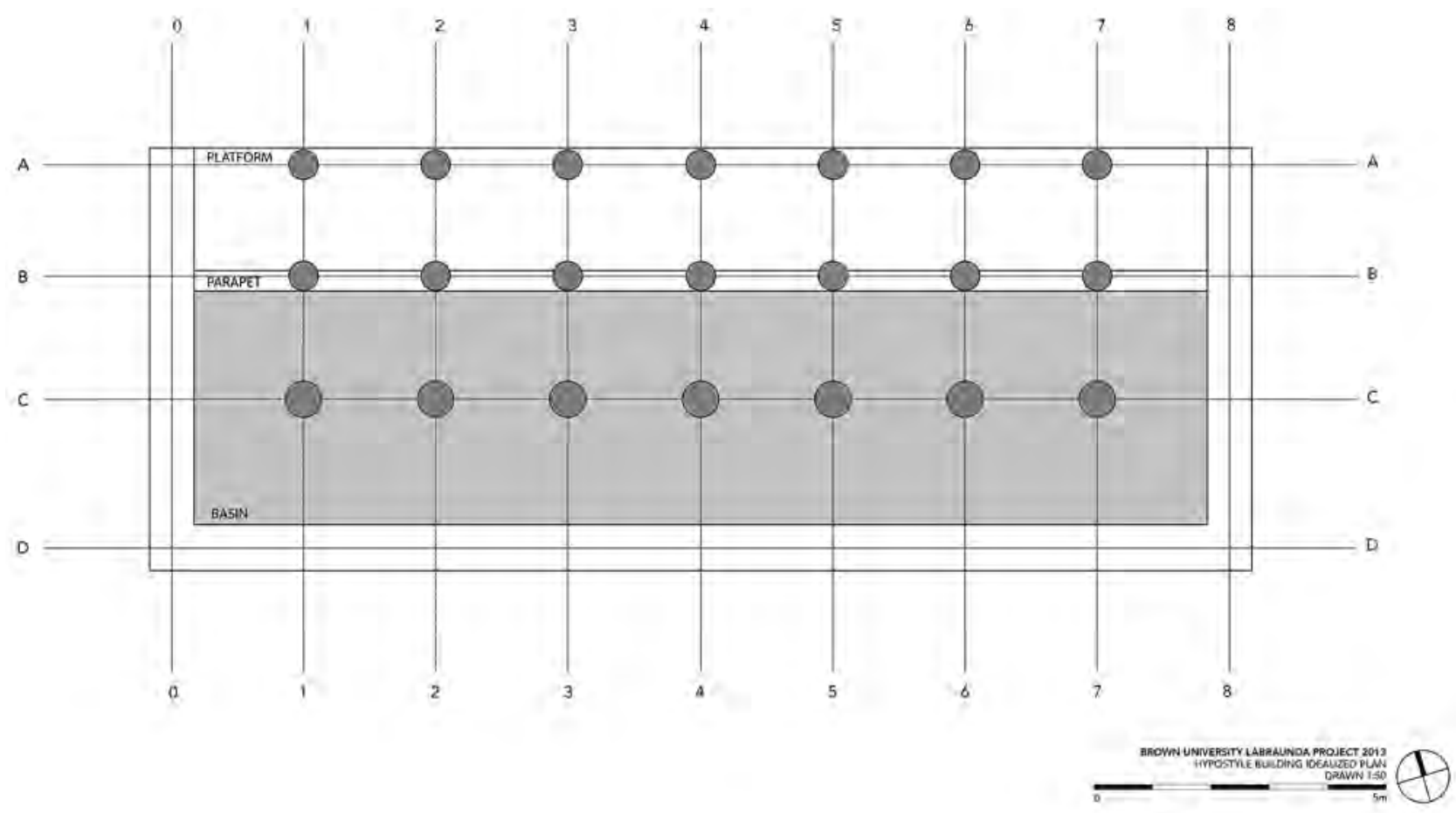

Fig. 83 : Schematic plan of the HB showing column grid, platform, parapet, and basin (credit: BULP). 


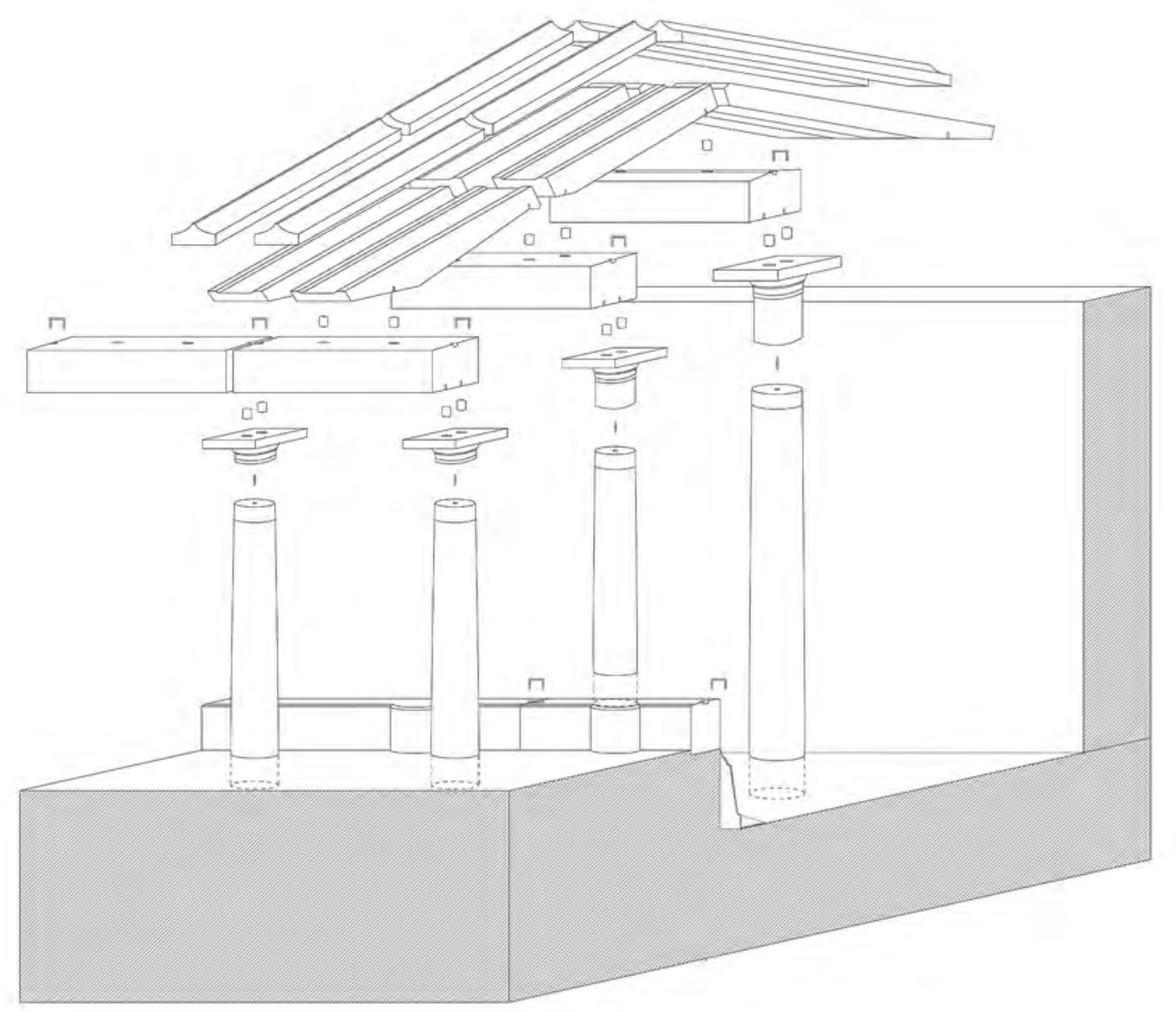

Fig. 84 : Schematic exploded axonometric of HB showing most common block types, clamping, and doweling (credit: BULP).

\subsubsection{History and Importance of research}

\section{History of research}

Although the $\mathbf{H B}$ has been exposed since antiquity, it has received little academic attention. In 1936, Alfred Laumonier published an article surveying the archaeology of Karia and dedicated two pages to the structure ${ }^{60}$. Laumonier's account of the $\mathbf{H B}$ is generally sound, especially considering that he did not conduct any excavation. He published a photograph of the building's remains as well as measured drawings of a few architectural blocks. Furthermore, he noted that the HB had an uneven number of columns and speculatively associated the monument, which he described as a "bizarre portique", with the sacred eel ponds said by Pliny and Aelian to have existed in Labraunda ${ }^{61}$. Laumonier also recorded that the HB was made of granite, as opposed to gneiss, a slight misidentification that is repeated in the 'Labraunda' entry of the Princeton Encyclopedia of Classical Sites ${ }^{62}$.

Although Axel Persson, the scholar who led the early Swedish expedition to the site, did not excavate the $\mathbf{H B}$, there are a few seconds of footage of him

60) Laumonier 1936.

61) Pliny $H N$ 32.16; Aelian De Natura Animalium 12.30.

62) W.L. Macdonald, "Labraunda", Princeton Encyclopedia of Classical Sites Online (Last accessed through Perseus on August, $31,2013)$ 
walking through the ruins of the monument in a 1949 Swedish documentary about life at Labraunda ${ }^{63}$. In the same year, a few trenches were dug by the Swedish expedition immediately north of the HB. The entire documentation of these soundings amounts to one simple sketch plan and a few sentences summarily describing the stratigraphy and ceramic finds; these can be found in the relevant notebooks of the Swedish expedition. There is also some institutional memory about the result of those soundings: Jesper Blid and Ragnar Hedlund told us informally that the entire area between the E propylon and the $\mathbf{H B}$ was crisscrossed by water pipes.

In Pontus Hellström's 2007 guide of Labraunda ${ }^{64}$, the HB is described as a well-house "evidently of Roman date". Although Professor Hellström gives no explicit reason to support this dating in his book, he told us (viva voce) that he assumed that Hekatomnid and later Hellenistic monumental architecture in Labraunda was of more refined facture and generally made at least partly of marble, while later Roman architecture was of lower quality and made of gneiss. Following Laumonier, Professor Hellström also tentatively associated the building with the eels mentioned by ancient authors.

In 2009, geophysical prospection was carried out in the environs of the $\mathbf{H B}$, but the specialists did not conduct work in the immediate vicinity of the building most likely because of the block tumble ${ }^{65}$. In 2011, Elifnaz Durusoy surveyed the area and made basic AutoCAD plan and section drawings of the $\mathbf{H B}$ and the $\mathrm{S}$ terrace wall ${ }^{66}$.

\section{Importance of Research}

The fact that the HB has not received much academic attention before 2013 says more about $20^{\text {th }}$ century archaeological practices and prejudices than it does about the building's importance and interest. The HB is arguably the grandest fountain house in Labraunda - a religious site where water played a key role, even after the demise of polytheism. While there are several monumental fountain houses in or near the sanctuary (including the so-called Doric House by the S propylon, the Hellenistic fountain $\mathrm{S}$ of the $\mathrm{M}$ terrace, and the yet unexplored monumental fountain NW of the temenos), the $\mathbf{H B}$ is the largest of all of these, and also the most conspicuous. Since the HB lies next to one of the main entrances to the sanctuary, there is little doubt that it would have greeted pilgrims, perhaps specifically those coming to the sanctuary from cities in the $\mathrm{N}$, such as Alinda and Alabanda, rather than those coming from Mylasa and Halikarnassos in the W.

In addition to its significance as one of Labraunda's principal fountains, the monument is also an important and intriguing example of vernacular monumental architecture in Western Anatolia. How and when did such an ambitious monument come to be? Who funded its construction, and why? Perhaps more interestingly from a strictly archaeological perspective, how was it designed and built, by whom, and why precisely in that location? The HB has the potential to shed light not just on the history of monumentalization and water-management in the sanctuary, and on the experience of pilgrimage at Labraunda, but also, and more generally, on how the people of Western Anatolia adopted and transformed Greek and Roman architectural traditions and practices. Aesthetic and structural details can shed light on how Karian designers and builders, who were only partly familiar with Greek architectural traditions, tackled the challenges of building a monumental structure in stone. Nowhere is local Karian intervention more apparent than in the fountain's bizarre roof, where gneiss slabs that weigh over a ton were made to look like ceramic roof tiles. These unwieldy roof tiles immediately call to mind other structures in inland Karia including those of the socalled 'temple' at Gerga. Many of the great marble monuments of classical Anatolia have been the object of detailed archaeological and architectural studies; our intention in undertaking this project is to apply the same painstaking analysis that is usually reserved for canonical classical architecture to this fascinating, yet almost unexplored monument.

\subsubsection{Excavation}

The remainder of this document describes briefly the three trenches excavated during the 2013 season.

\section{Trench $A$}

\section{Trench Description and Objectives}

Trench A covered an area of approximately $4 \mathrm{~m}$ by $11 \mathrm{~m}$ at the NE end of the HB (see Fig. 85). The

63) Labranda: med svenska arkeologer i Turkiet directed by E.A. Lingheim.

64) Hellström 2007.

65) Prospection was conducted by GGH-Solutions in Geoscience and a report was submitted to professor Karlsson under the title: "Geophysical survey at Labraunda-Project, Milas, Turkey: Report 2009".

66) Karlsson et al. 2012 : fig. 50. 


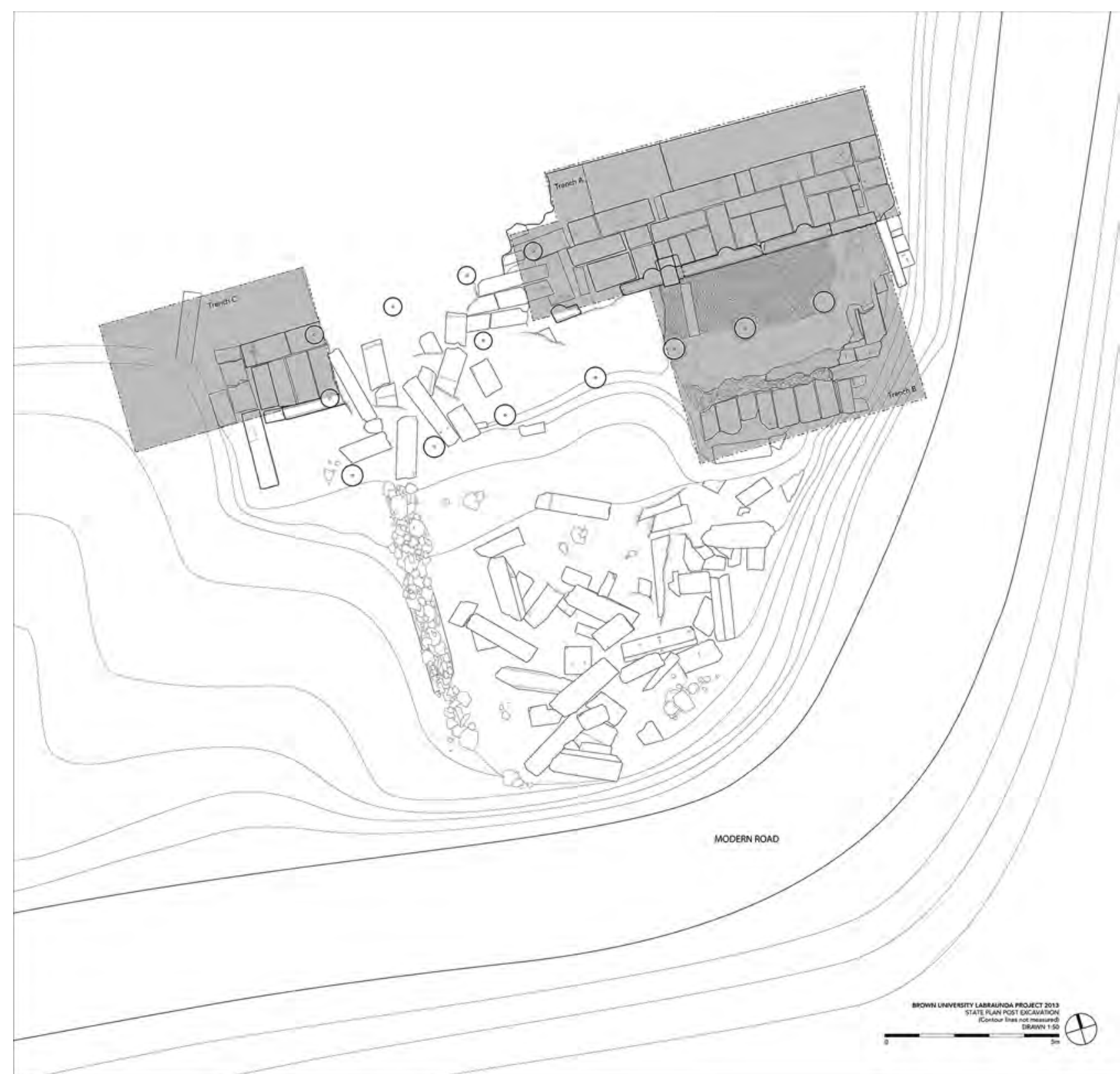

Fig. 85 : State plan post excavation showing location of trenches; contour lines not measured (credit: BULP).

E end of the platform and the parapet marked the trench's $\mathrm{E}$ and $\mathrm{S}$ limits; a line $4 \mathrm{~m} \mathrm{~N}$ of the parapet and parallel to it marked the trench's N limit; column row 4 served as its $\mathrm{W}$ limit. By the end of the season, we had exposed the platform within the trench, and also dug a deep sondage down to the foundations of the platform.

Our primary objective in trench A was to explore the architecture of the $\mathbf{H B} \mathrm{N}$ of the parapet, particularly the platform, which was partly visible in the E even before excavation. Additionally, we wanted to learn about the $\mathrm{N}$ access to the fountain. The trench even- tually provided an opportunity to study the history of occupation of the HB as well as the collapse and abandonment of the structure. Towards the end of the season, we excavated a sondage $\mathrm{N}$ of the platform in order to study the building's substructure and foundation (Fig. 88).

\section{Collapse and Abandonment}

Prior to excavation, the area of Trench A was covered in a combination of grassy topsoil (a1) and block tumble; however, the middle parapet and por- 


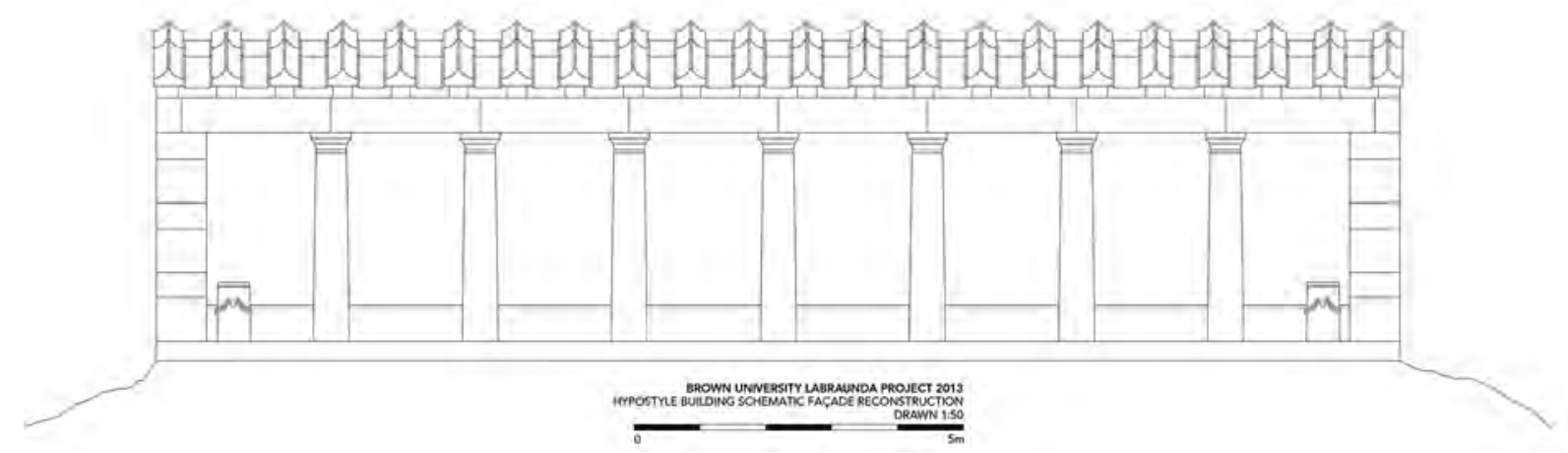

Fig. 86 : Schematic and idealized elevation of $\mathbf{N}$ façade (credit: BULP).

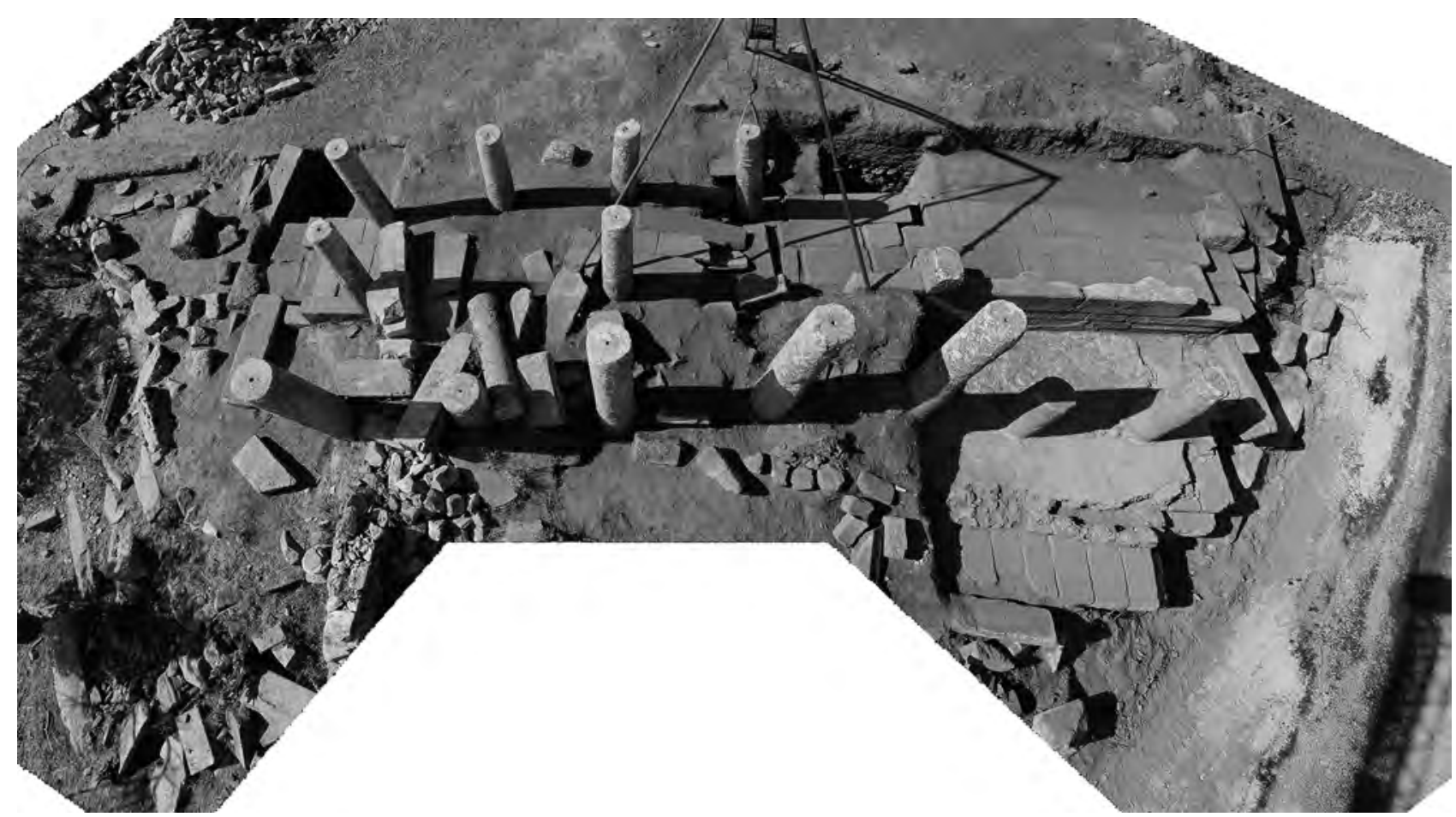

Fig. 87 : Aerial view of HB post excavation looking $\mathbf{N}$ across axis of $\mathrm{HB}$ (photo: BULP).

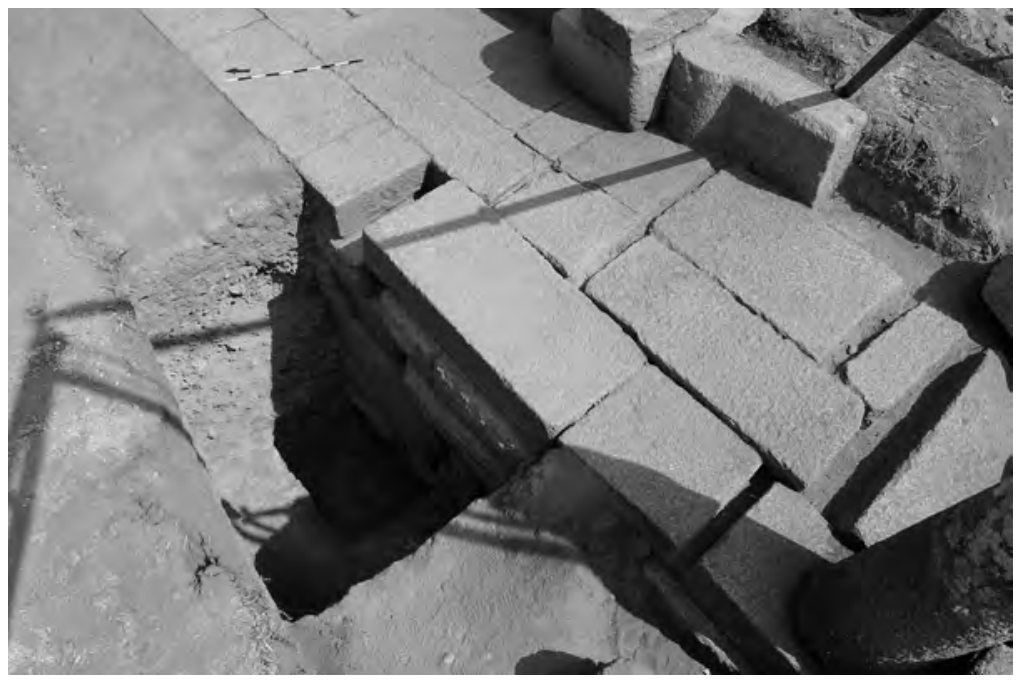

Fig. 88 : View of parapet, platform, and sondage in Trench $A$ that reached bottom of foundation (photo: BULP) 
tions of the platform were partially visible in the $\mathrm{E}$ end of the building (see Fig. 82). After removing the tumble, excavation began in earnest and more of the platform was quickly uncovered. A floor made of ceramic and stone tile (a3) was discovered $\mathrm{N}$ of column B6 below the topsoil. This even surface of irregular tiles was later found to extend $\mathrm{W}$ to around column B5, and was no doubt the remains of Late Antique occupation of the building. Throughout the trench, excavation of the topsoil produced substantial amounts of tile and pottery, as well as some glass and bone. The pottery dated to multiple periods ranging from Late Classical to Late Antique.

\section{Late Antique Adaptive Reuse}

As the topsoil continued to be cleared to the $\mathrm{W}$ of the tile floor, more architectural features were found including a large marble threshold block, along with a tumble of large irregular stones immediately $\mathrm{N}$ of the block. This threshold was not part of the original $\mathbf{H B}$; rather, it appears to have been associated with the tile floor and also with a drystone wall (a14), meager remains of which were found running all the way up to the $\mathrm{N}$ limit of the trench from column A4. Additionally, an extensive rock pile (a9) was uncovered $\mathrm{N}$ of the tile floor between A5 and A6. These features seem to have all been part of a later occupation of the HB, and are probably connected to similar features found in trenches B and C. The purpose and function of this structure are unclear, but the tile floor and wall tumble show a repurposing and reorganization of space on top of the platform and immediately $\mathrm{N}$ of the HB. The exact date of this later occupation is not known, but it is almost certainly Late Antique. The pottery assemblage from in and around these features is mixed, but includes copious amounts of Roman and Late Antique ceramic and tile, and the tile floor appears to be consistent with Late Antique construction methods in other parts of Labraunda. The evenness of the later floor compared with the disjoinded state of the platform beneath it (see below) suggests that this floor was laid down after the moment when the foundation became disarticulated.

\section{Hellenistic-Late Antique Fountain}

The tile floor was removed to reveal a layer of dark rich soil (a4/8), which lay directly on top of the platform. Unlike the platform E of B6, the section of platform in the $\mathrm{W}$ half of the trench was broken and disarticulated - sloping $\mathrm{W}$ and $\mathrm{S}$ with large gaps between blocks, in particular between columns A5 and A6, going all the way from the top of the platform to the lower levels of the foundation (see Fig. 88). Looking through this gap, we were surprised to find that the stylobate was sometimes resting on small roughly cut stones rather than on ashlars. The HB seems to have caved in, and there is a large depression, clearly visible but not yet excavated, between columns 3 and 4 in the A and B rows.

Eventually we opened up a sondage $\mathrm{N}$ of the large break in the platform with the aim of reaching the bottom of the HB's foundation. Initially digging through a loose, brown deposit (a10) similar to the topsoil, we reached a layer of sand and gravel (a13). Immediately on top of this layer, a well-preserved bronze coin was found (SF \#2), which was later identified as an issue from Miletus dating to around 313/2-290 B.C. (Fig. 89) ${ }^{67}$. Ceramics from this context include a stamped Attic black-glazed ring base with a roulette-and-palmettes motif which dates from the early $3^{\text {rd }}$ century B.C. (Fig. $90{ }^{68}$. We next encountered a new context that was similarly rocky, but more yellow in color (a15); from this context we found only a few pieces of pottery almost certainly of Hellenistic or earlier date.

Beneath this context (a15), and on a level with the fifth course of the foundation counting down from the stylobate, we finally reached the undisturbed bedrock (a16). The bottom of the foundation was cut into extremely friable and micaceous bedrock, six courses and $3.374 \mathrm{~m}$ below the top of the stylobate. In the process of digging the sondage, we revealed a cutting in the bedrock corresponding to the original foundation trench. The sixth and part of the fifth course were probably placed into the cut bedrock, while the gravelly layers above bedrock were apparently laid down as the foundation was built up, and seem to correspond with different courses of the foundation.

The gap visible at platform level extends all the way to the base of the foundation; through this gap, part of the inside of the foundation could be viewed. The foundation not only included small stones, but the inward faces of at least some of the blocks were uncut. It is possible that this imperfect construction, as well as the weakness of the bedrock led to the catastrophic collapse of the building. 

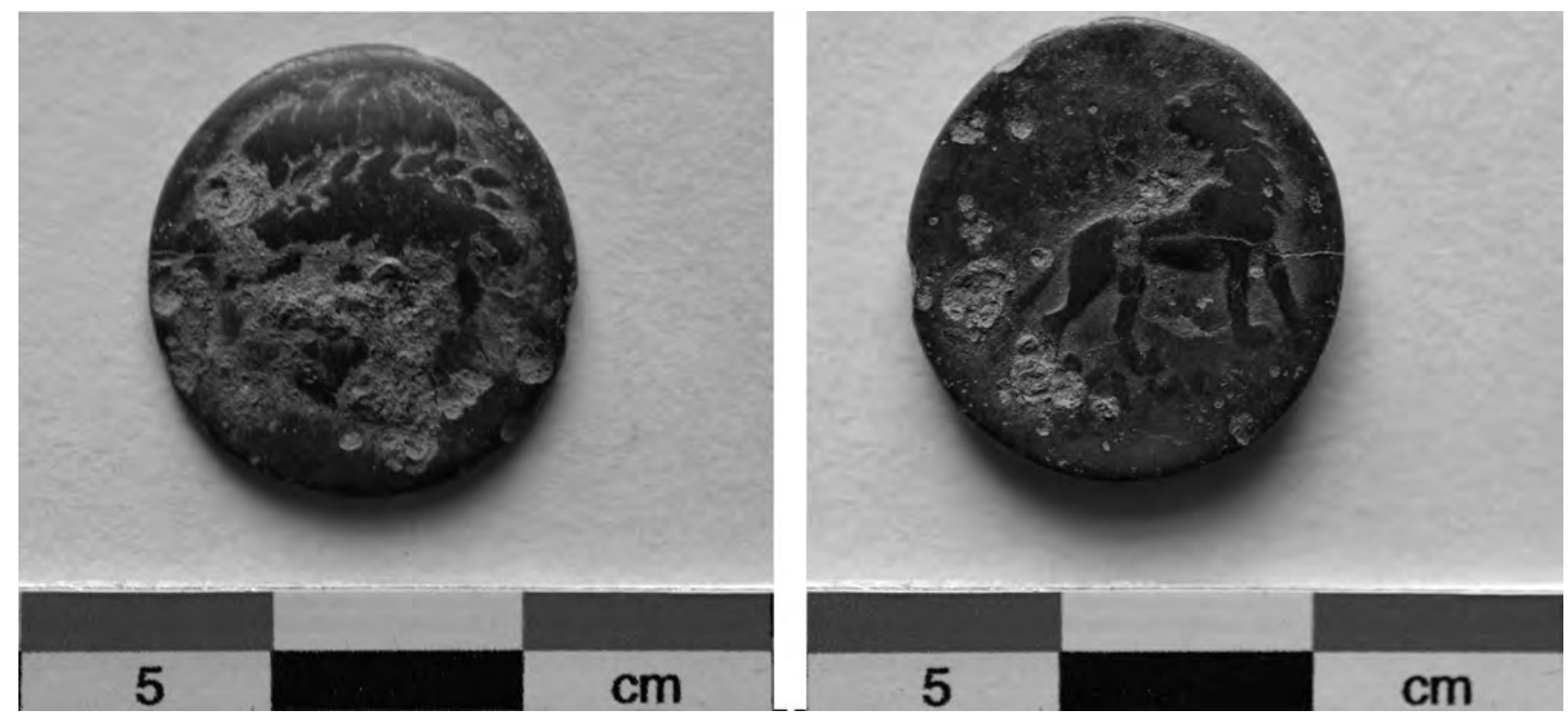

Fig. 89 : Coin of Miletus found in Trench A (photo: BULP).

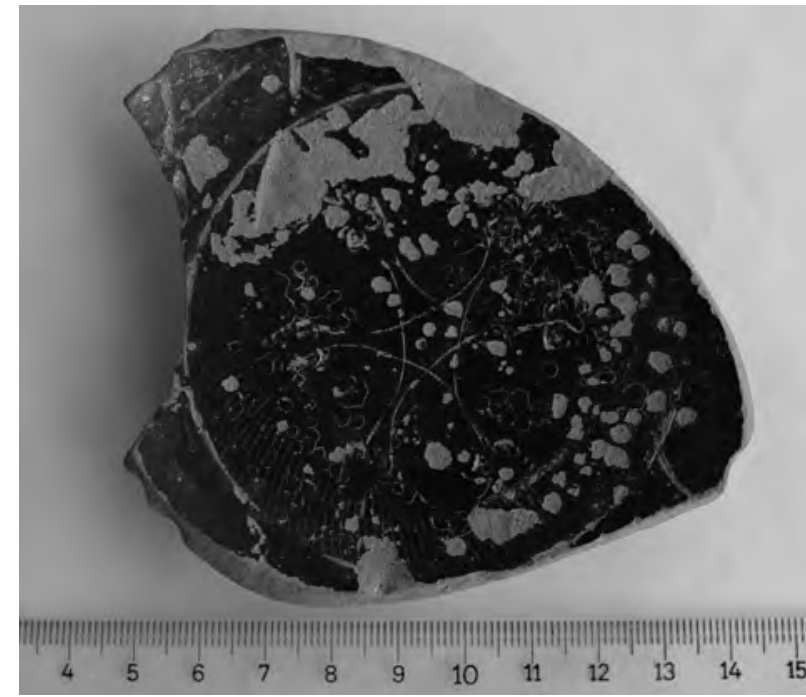

Fig. 90 : Fragment of Attic black glazed ring foot found in Trench A (photo: BULP).

\section{Future Work}

Trench A has done much to elucidate the construction and history of occupation of the HB; however, many questions remain. The weakness of the foundation and underlying bedrock must have contributed to the collapse of the building, but the ultimate cause probably lies $\mathrm{E}$ of Trench A, where a large depression can be seen between columns 3 and 4 in the A and B rows (see Fig. 88). Future excavation of this area should allow us to learn why the entire middle of the platform and indeed the entire HB caved in. Further excavation to the $\mathrm{N}$ is also needed in order to understand how water entered the fountain.

\section{Trench $B$}

\section{Trench Description and Objectives}

Trench B (see fig. 85) was bounded on the $\mathrm{N}$ by the parapet, on the E by the E wall of the $\mathbf{H B}$ that was cut by modern road construction, on the $\mathrm{S}$ by the hypothetical S wall of the basin, and on the W by a line extending along row- 5 columns. After preliminary cleaning of the area $\mathrm{S}$ of the parapet over the basin (which was partially visible in section from the modern road), a trench of approximately 7 $\mathrm{m}$ by $5 \mathrm{~m}$ was laid out in the SW portion of the HB. This area appeared vulnerable to future damage because of its proximity to the modern road, so it needed the most immediate attention.

Through trench $B$ we wanted to determine the $S$ extent of the HB and to further examine its architectural construction. Most importantly, we wanted to investigate whether or not the building was indeed a fountain, as there was no sign of hydraulic mortar or pipes in the already exposed portion of Trench A. Indeed, Trench B has helped to prove unequivocally that this building was constructed as a monumental fountain and maintained as such over a long period of time. Additionally, Trench B provided evidence for the abandonment of the building and subsequent adaptive reuse of the structure in Late Antiquity.

\section{Collapse and Abandonment}

The entire trench was covered in a thick layer of topsoil with the roots of bushes (b1) that had accumulated over the fallen gneiss blocks that once were the roof of the building (b2). Since the collapsed 
blocks corresponded to all shapes that came from the upper part of the $\mathbf{H B}$, it appears that the roof was standing long after this building was no longer used as a fountain. It then collapsed in a single incident, perhaps a sudden shift of the bedrock under the foundation. These blocks were removed using a winch and a Caterpillar in order to excavate the rest of the trench.

Directly under the topsoil and collapsed blocks was a thick accumulation of sandy soil with very few pieces of tile, pottery, or other artifacts. This layer, present both $\mathrm{N}$ and $\mathrm{S}$ of the $\mathrm{C}$-row of columns (b3) and over the S extent of the basin (b4), appears to have been carried into the building by flooding and wind, as indicated by various thin lenses of pebbles and sand. The presence of these layers indicates that the building was abandoned before the roof collapse.

\section{Late Antique Adaptive Reuse}

Under the abandonment layers, we uncovered several layers and features that provided evidence for a period of habitation - or at least modification - of the structure in Late Antiquity. During this time, what was once the water basin for the fountain was partially leveled with a deposit of dark, micaceous soil (b5) containing a high concentration of tile, large rocks, and ceramic. This was likely drawn from a nearby area in order to cover and level the partially destroyed plaster basin.

$\mathrm{S}$ of the C-row of columns was a layer (b7) of large stones; these included three worked blocks of marble as well as worked and unworked gneiss stones; notably, none of these corresponded to shapes found in the roof of the building ${ }^{69}$. These collapsed blocks were likely once part of a dry-stone wall constructed in the intercolumniations between $\mathrm{C} 5$, 6 , and 7. The layer directly below the wall collapse (b9) contained pottery from the $5^{\text {th }}$ and $6^{\text {th }}$ centuries A.D., suggesting that the reoccupation dated to this period $^{70}$.

This evidence for reuse in the southern portion of the HB may be contemporaneous with the Late Antique tile floor discovered in the other two trenches. Although it is unclear whether this was domestic habitation or some other kind of occupation, the material assemblage associated with the collapsed Late Antique wall provides a concrete date by which the HB was no longer used as a fountain; it also adds another example to the many cases of adaptive reuse of earlier monuments in Late Antique Labraunda.

\section{Hellenistic-Late Antique Fountain}

In addition to showing a clear sequence for the later occupation, abandonment, and final collapse of the HB, Trench B was crucial for providing a picture of the building's use as a monumental fountain. Although we still do not know how water entered or exited the basin, Trench B provides clear evidence of many layers of hydraulic mortar and plaster within a basin that probably ran the length of the building $\mathrm{S}$ of the parapet (see Fig. 87 where the basin is partially exposed). In addition, it is evident that the basin must have had a substantial back (S) wall up to $100 \mathrm{~cm}$ in width, which is the distance between the end of the plaster floor and the edge of platform (the width of the back wall can be surmised from the un-plastered portion of basin, immediately $\mathrm{S}$ of the $\mathrm{C}$ row of columns visible in figure 7). Although several reconstructions are possible, we hypothesize that a wall or a fourth row of columns stood on top of this back wall (see below).

At least four distinct plastering episodes of the basin floor are discernible in section on the E side (Fig. 91); the top two floors were both exposed in excavation (b10, b11). A partially preserved patch on the southern side of the wall below the parapet (b6) was also uncovered. The latest phase of plastering was in poor condition, or perhaps never completed. Across much of the basin, this layer (b10) consisted only of loose lime and sand mixed with mediumsized rocks and broken terracotta tile fragments that were used as floor preparation. However, in several patches $\mathrm{N}$ of the $\mathrm{C}$-row of columns, a finished floor surface was preserved. A rectangular area of this floor between the parapet and the C-row of columns between $\mathrm{C} 5$ and $\mathrm{C} 7$ was left in situ. The composition of this plaster is typical of Late Antique plaster in other Labraunda monuments, such as the tetraconch structure. It was distinct from the plaster layers below it, which were made using large pieces of terracotta tile and pinkish hydraulic mortar, but no rocks. Directly under this Late Antique phase, which was the final phase of the building's use as a fountain, was a well-preserved and fine pink plaster floor (b11). It was thin and flat, with elegant molding

69) This fact, in addition to the stratigraphy of the abandonment and roof tumble above this collapsed wall, suggests that the roof remained either completely or mostly intact during the later reuse of the building.

70) Similar cases of adaptive reuse with walls constructed in intercolumniations have been found in other parts of Labraunda, including this season in the trench on the M terrace excavated by Dr. Jesper Blid and Dr. Ragnar Hedlund (see section 4.3 supra). 
along all of its edges, including around the C-row column bases (Fig. 92). The two or more plaster floor layers below this remain unexcavated.

In addition to the plaster floor, we exposed the gneiss blocks of the southern platform (see Fig. 91). The lack of plaster on the S portion of these blocks, in addition to horizontal plaster-filled grooves on them seem to indicate that the fountain had a thick back wall to contain the water. Nothing of the wall remains. In the $\mathrm{S}$, the topmost course of the basin fell $\mathrm{S}$ at a later date because it was not clamped to the blocks directly $\mathrm{N}$ of it. This created a crevice along the southern extent of the plastered basin, which later filled with loose dirt (b12) (Fig. 93).

The extant evidence suggests that the water basin was maintained and successively repaired over a long period of time, perhaps from the Hellenistic period through Late Antiquity. The C-row of columns would have been submerged in the water, and the basin would have been bounded by a wall along its southern edge.

\section{Future Work}

Trench B was completely excavated this season. It helped to draw a clear picture of the building's use as a fountain, its reuse in Late Antiquity, and its final abandonment and collapse. Further study of the ceramic assemblage should help us refine the dating of each of these phases. Additional excavation next year to the areas directly $\mathrm{W}$ and $\mathrm{S}$ of Trench $\mathrm{B}$ will help clarify the appearance of the S part of the building, and demonstrate how water flowed into the basin from the $\mathrm{N}$ and out of it to the S. Future excavation might also clarify the nature of the adaptive reuse of the $\mathbf{H B}$ in Late Antiquity.

\section{Trench C}

\section{Trench Description and Objectives}

Trench C's N limit was defined by an E-W line that is parallel to the $\mathbf{H B}$ and $1.8 \mathrm{~m} \mathrm{~N}$ of the platform; its S limit was defined by the parapet itself. Row 1 columns marked its $\mathrm{E}$ end, while its initial $\mathrm{W}$ limit was marked by existing rubble terrace in the W. This originally encompassed an overall area of approximately $4 \mathrm{~m}$ by $6 \mathrm{~m}$, but our efforts quickly focused on a sondage measuring roughly $1.8 \mathrm{~m} \times 1.8 \mathrm{~m}$ immediately to the $\mathrm{N}$ of the HB's NW corner (see Fig. 85). The primary objectives for this trench were to better understand the NW corner of the $\mathbf{H B}$, its foundations, and its relationship with Labraunda's monumental $\mathrm{S}$ terrace. The excavations aimed to expose the substructure of the $\mathbf{H B}$, to

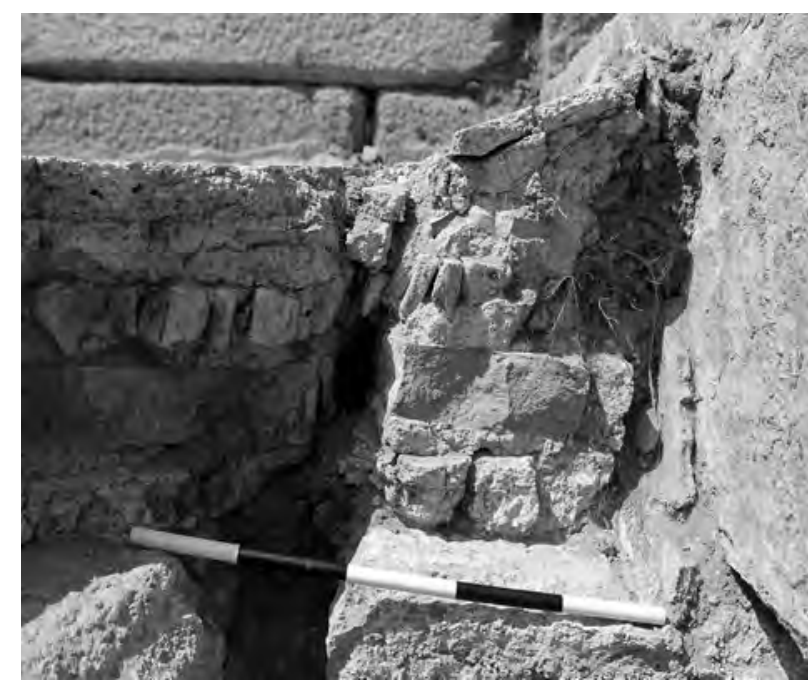

Fig. 91 : Detail of successive layers of tile and plaster floors from NE corner of basin (photo: BULP).

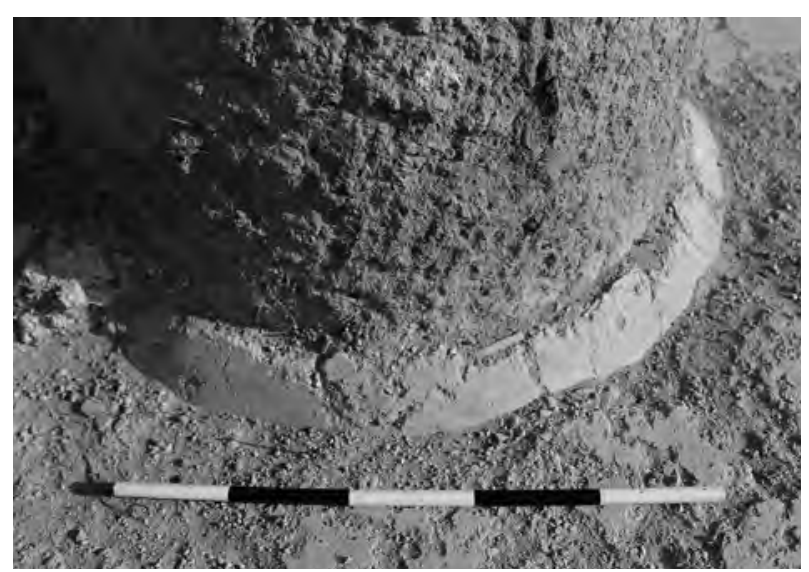

Fig. 92 : Detail of plaster around bottom of column C6 (photo: BULP).

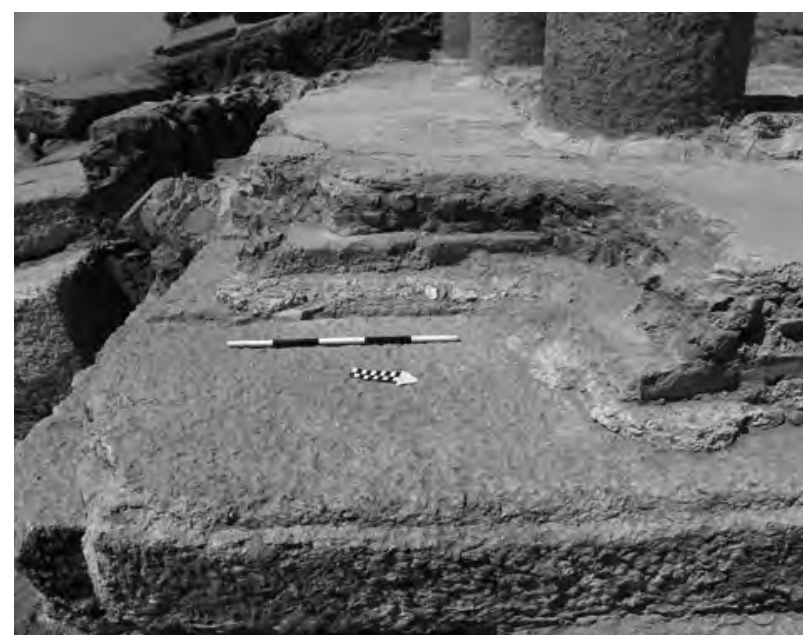

Fig. 93 : Detail of bottom of basin, successive layers of tile and plaster, and disarticulated S section of basin (photo: BULP). 
clean and partly expose the $\mathrm{W}$ façade, and to reach the $\mathrm{S}$ terrace wall in the $\mathrm{W}$.

Prior to excavation, Trench $\mathrm{C}$ was covered with topsoil of variable thickness (c1). As in Trenches A and $\mathrm{B}$, the topsoil had accumulated on top of blocks from the roof collapse (c2) and included abundant ceramics and tiles of all periods. A heavily weathered coin was also uncovered on topsoil (c1) and a second similar coin was found slightly $\mathrm{S}$ of the trench upon the surface (c2); both coins were corroded and unidentifiable. In the $\mathrm{W}$ of the trench, a line of stones (c3), associated with an in situ water pipe, was uncovered. This line of stones extended E-W for a length of $2.28 \mathrm{~m}$ (seemingly towards the structure being excavated in 2013 by Dr. Ömür Çakmakl1, see section 4.5 below). The area in which the pipe was found was not excavated during the 2013 season, so its date and its relationship to the $\mathrm{S}$ terrace and $\mathbf{H B}$ remain unknown.

\section{Collapse and Abandonment}

The stratigraphic sequence within the columns of the $\mathbf{H B}$ differed from that outside the structure. Initial work within the columns in Trench $\mathrm{C}$ involved the removal of a field wall running roughly $\mathrm{N}-\mathrm{S}$ along column row 1 . This dry-stone wall (c7) included reused architectural elements from the HB. Early photographs of the $\mathbf{H B}$, which do not include the field wall, show that it was constructed sometime after the 1950s. Underneath (c7) and immediately $\mathrm{N}$ of the parapet (c14) was a loose deposit (c6) containing a variety of building material from all periods. This context extended both underneath and above the collapse inside the structure. Below (c6) was another deposit (c5), which contained significantly less ceramic material, and few roof or floor tiles. The yellow-brown color and sandy-silt composition of this deposit (c5) is similar to a layer encountered in Trench B (b3/b4) at a similar level and may represent a long period during which the building was still standing, but abandoned.

\section{Late Antique Adaptive Reuse}

Below context (c5) a single tile was exposed, likely in situ, of what was once a larger floor surface. This tile may represent a later occupation surface similar to that exposed in Trench A (a3) at a comparable elevation above the platform. In addition to the tile, a beaten-earth floor surface (c8) extended over the stylobate in the $\mathrm{N}$ and almost to the $\mathrm{W}$ extent of the building. This beaten earth floor was completely excavated. Ceramic materials and building tiles await further study, but preliminary dating sug- gests that this is a Late Antique occupation. Underneath the beaten-earth floor (c8) was the original platform (c12) of the HB: a series of three large rectangular ashlar blocks on a N-S alignment.

\section{Hellenistic-Late Antique Fountain}

To better understand the stratigraphy below subsoil deposit (c4), a sondage (B) of $1.8 \mathrm{~m}$ by 1.8 $\mathrm{m}$ was opened immediately to the $\mathrm{N}$ of the HB. Below subsoil we encountered a very dark brown, almost black, deposit (c9), which included a wealth of ceramic material and faunal remains. The deposit was interspersed with lenses of lighter, dryer material (c13). Ceramics recovered from this deposit (c13) dated primarily from the $1^{\text {st }}$ century A.D. onwards.

The sondage further revealed that the foundations of the HB (c12) were roughly cut, poorly joined, and not clamped; at least at the NW corner, they included large ashlars. As in trench A, the foundations in Trench $\mathrm{C}$ are visibly disarticulated. The presence of several large boulders $\mathrm{N}$ of the stylobate and lining the bottom of the sondage under layer (c9) might indicate that large rocks were placed around the actual foundation to buttress the structure and increase the stability of the blocks in the NW corner of the building.

\section{Future Work}

From the excavations in Trench $\mathrm{C}$, we can reach a number of preliminary conclusions. First, as was already clear in Trench A, Trench $\mathrm{C}$ excavations confirmed that the foundations of the HB appear to be poorly designed and built. The $\mathrm{W}$ portion of the platform (c12) has slipped away from the rest of the building leaving large gaps between the platform blocks. The sondage to the $\mathrm{N}$ of the stylobate (c11) also indicates that only the stylobate of the HB stood above ancient ground level. Although poorly understood, the in situ water pipe uncovered in the $\mathrm{W}$ section of the trench brings to mind the reports by Swedish team members of similar pipes found in the area. The organic, wet deposit (c9) also indicates the continued presence of a source of water to the $\mathrm{N}$ of the structure. After the collapse of the monumental fountain, the structure has continued to act as a dam partially blocking the flow of water from an underground source. Much like the evidence in Trenches $\mathrm{A}$ and B, Trench C also shed some light on later occupation of the $\mathbf{H B}$.

There are many remaining questions to be addressed in future seasons. The relationship between the building and the $\mathrm{S}$ terrace wall is still unknown. Furthermore, although the dark brown deposit (c9) 


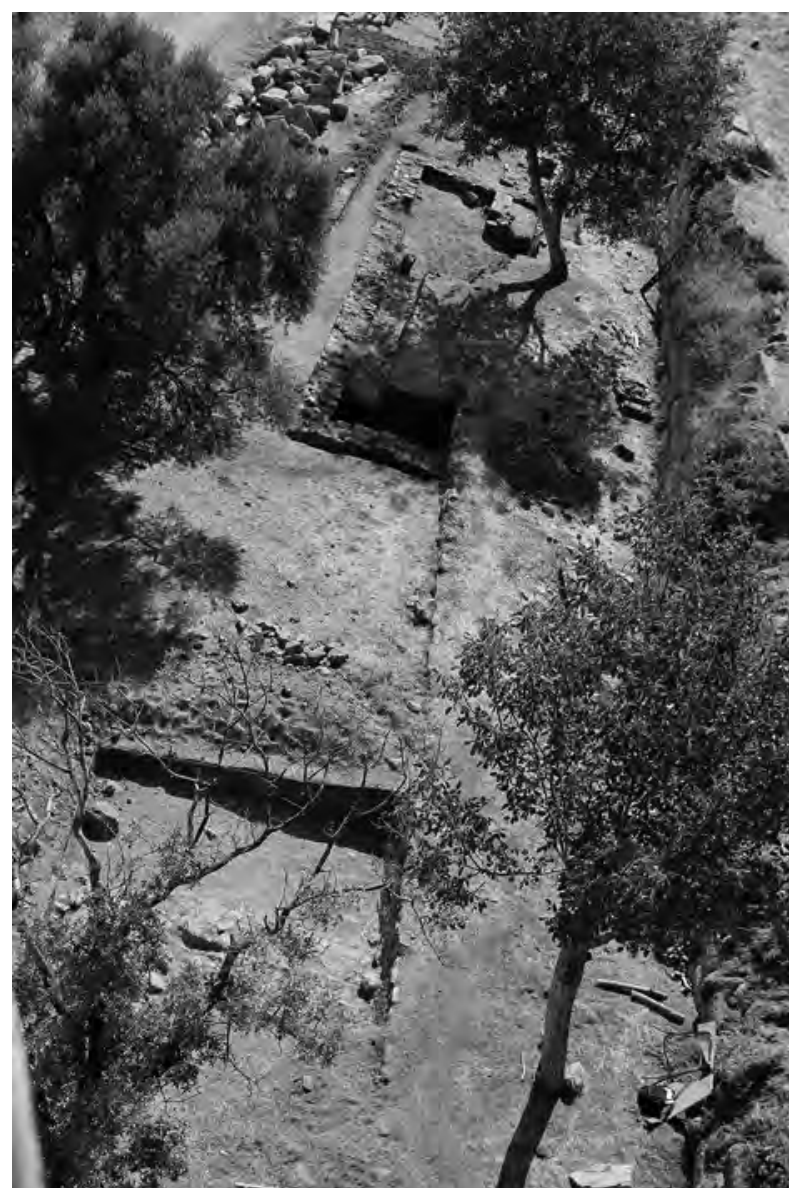

Fig. 94 : Vue générale des sondages dans la zone méridionale (photo : A. Waters).

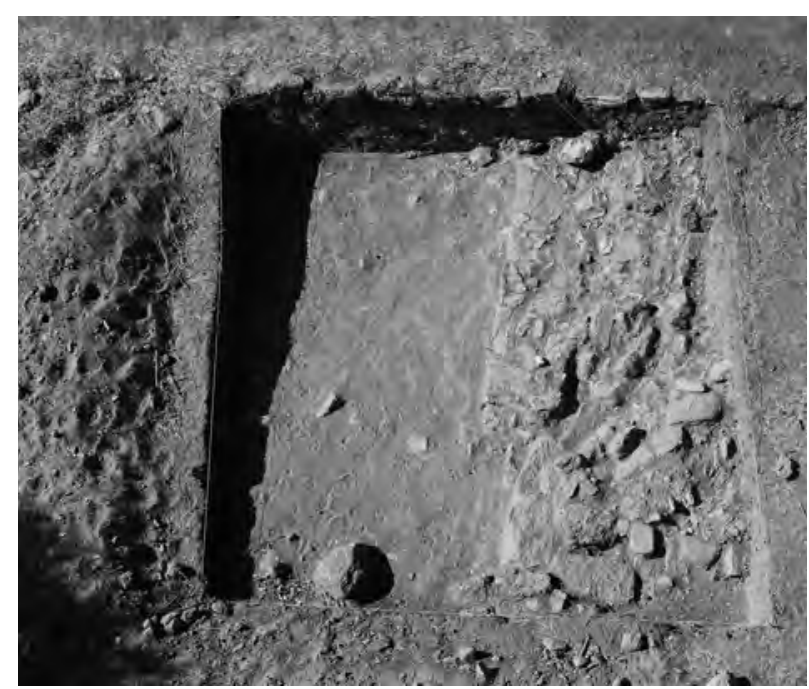

Fig. 95 : Vue aérienne de la tranchée 1 (photo: A. Waters). encountered suggests water entering the building from the $\mathrm{N}$, the path of water in and out of the basin is uncertain.

\subsection{La zone méridionale du sanctuaire (Fig. 94)}

(par Ö. Çakmakl1, chercheuse indépendante)

L'exploration de la zone au Sud du sanctuaire, le long de la route asphaltée qui mène de Milas vers Aydın, avait pour objectif de dégager cet espace des terres de remblais qui s'y étaient accumulées et de faire apparaitre le long mur $(100 \mathrm{~m})$ qui soutient la terrasse du propylon sud du sanctuaire. Avant de procéder au dégagement des terres nous avons décidé d'effectuer une série de trois sondages afin de vérifier s'il existait des structures enfouies. La tranchée 1 se situe dans la partie orientale de la parcelle. La tranchée 2 au centre, la tranchée 3 dans la partie occidentale.

\section{Tranchée 1 (Fig. 95)}

La tranchée 1 couvre une superficie de $5 \mathrm{~m}$ de côté. Seules les terres arables ont été dégagées (sur $1.80 \mathrm{~m}$ de profondeur), permettant de mettre au jour l'arase de vestiges. Ces derniers semblent correspondre soit à un mur effondré ou à un niveau de sol perturbé. Cette structure, partiellement construite, forme un angle dans la partie méridionale de la tranchée. Le matériel récolté au cours de ce décapage n'est pas très riche, excepté pour un peson relativement bien conservé. La fourchette chronologique semble très large, de la période hellénistique à la période romaine tardive.

\section{Tranchées 2 et 3 (Fig. 96)}

La tranchée 2 a commencé avec une superficie de $5 \mathrm{~m}$ par $5 \mathrm{~m}$ puis a été entendue afin de rejoindre la tranchée 1. Là aussi seules les terres arables ont été décapées. Les vestiges mis au jour se composent d'une très large structure formée par une série de murs connectés définissant un espace rectangulaire. Les murs sont composés de petits blocs liés par un mortier hydraulique rosâtre très fin. Seul le mur sud de la structure a été entièrement dégagé. Il présente une largeur de $80 \mathrm{~cm}$ et s'étend sur une longueur totale de 17,60 m. Un sondage profond a été creusé dans l'angle sud-est de la structure, afin de préciser sa composition, son état de conservation, sa chronologie ainsi que sa fonction. L'emprise du sondage est de 2,65 $\mathrm{m}$ par 1,50 $\mathrm{m}$. La profondeur totale du creusement a été de $1,50 \mathrm{~m}$. Il apparaît que les niveaux mis au jour correspondent à un remplissage dû au ruissellement des eaux de pluie. Au fond du sondage on récolte une large quantité de matériel 


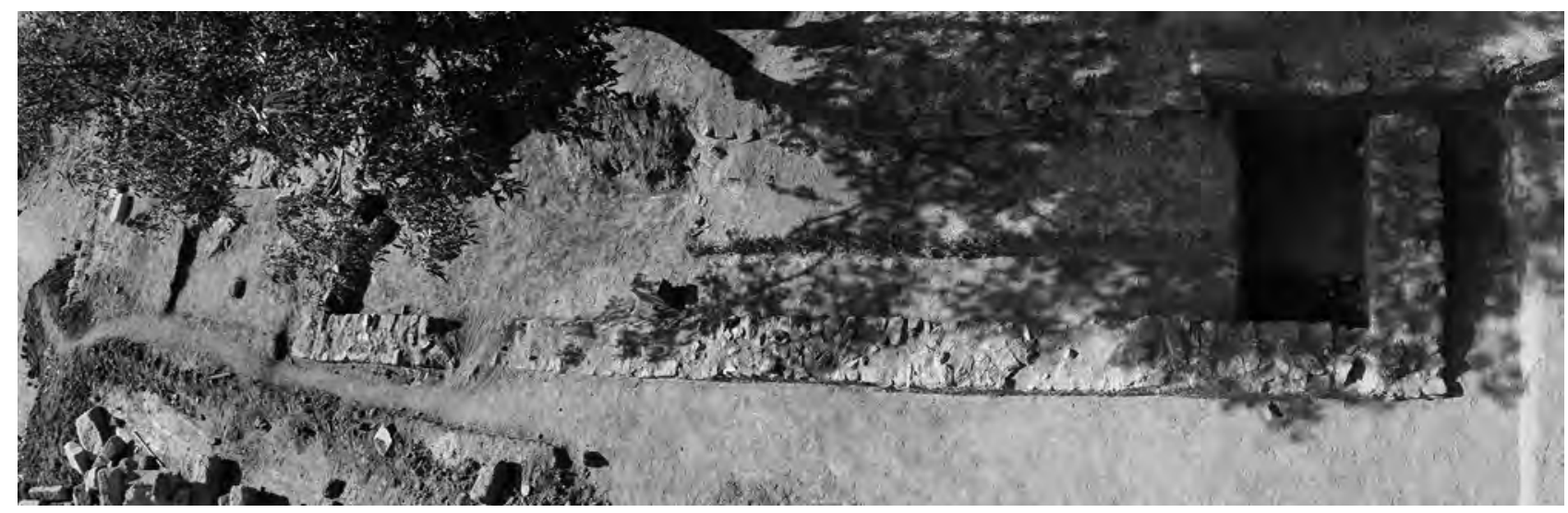

Fig. 96 : Vue aérienne des tranchées 2 et 3 (photo : A. Waters).

céramique, dont notamment une grande série de bol Cnidien des $\mathrm{I}^{\mathrm{e}}$ et $\mathrm{II}^{\mathrm{e}} \mathrm{s}$. ap. J.-C. Ce niveau de remblai correspond également à une arrivée d'eau, dont on a mis au jour la canalisation qui perce le mur est de la structure. On remarque de nombreuses traces de mortier hydraulique couvrant les faces internes de cet ensemble qui s'apparente très probablement à un très grand bassin de récupération des eaux de pluie.

La tranchée 3 a permis de révéler que ce bassin semble s'articuler sur une deuxième structure, plus large, et avec laquelle il partage son mur nord. Il n'est pas impossible que cette deuxième structure soit elle aussi un bassin et que l'ensemble présente une série de réservoirs en cascade (Fig. 97).
Dans l'état actuel de nos connaissances, et du fait de la faible profondeur des investigations menées en 2013, il est difficile d'avoir une vue d'ensemble de cet espace. La présence de grandes structures hydrauliques en contrebas du mur de terrasse sud est cependant surprenante. La saison 2014 visera à continuer le décapage entrepris cette année et poursuivre le sondage profond entamé afin de déterminer la profondeur totale des vestiges conservés. Nous chercherons aussi à déterminer le schéma de gestion (adduction, évacuation) des eaux et définir s'il existe un lien physique entre ces réservoirs et le bâtiment hypostyle.

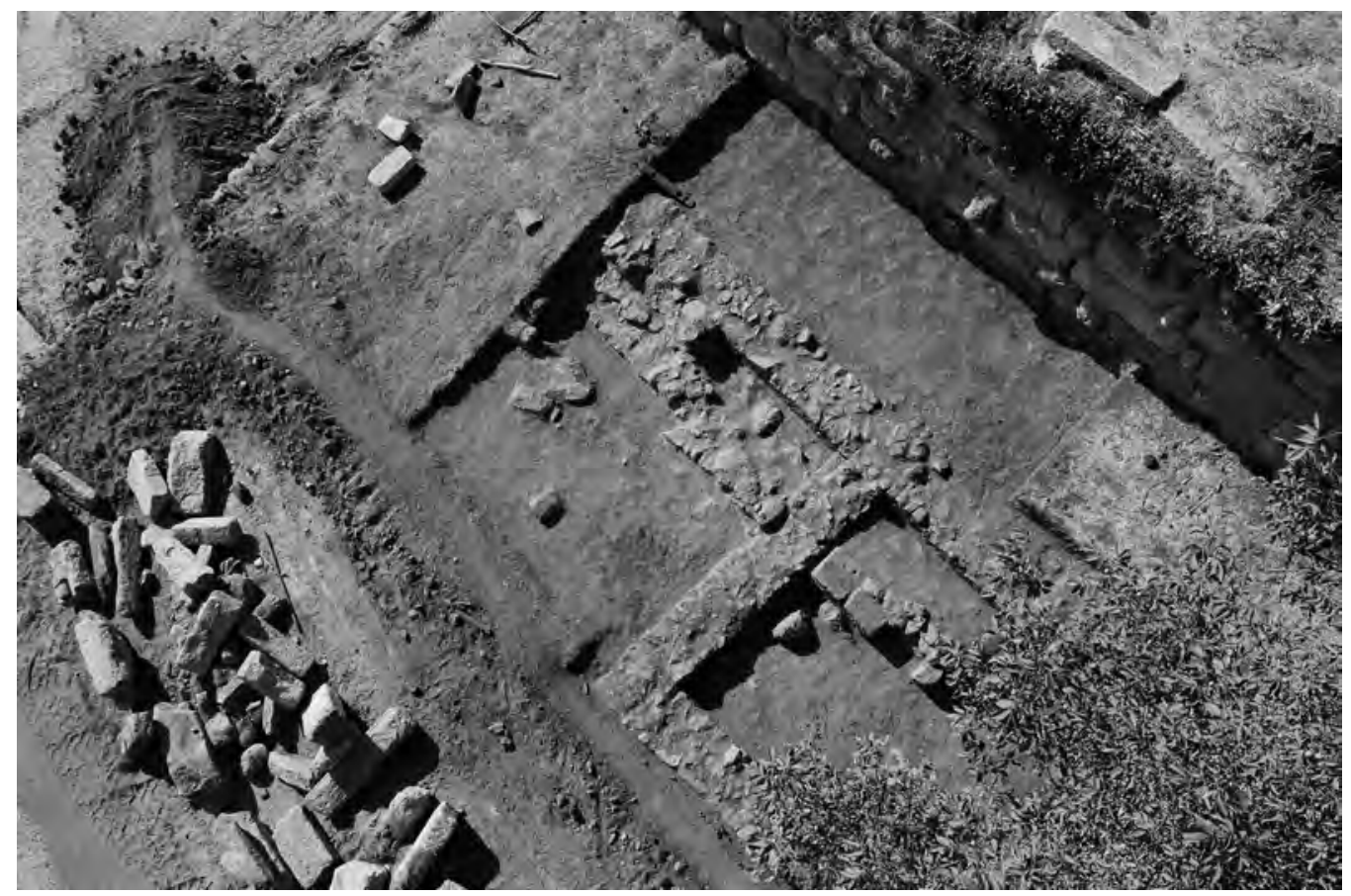

Fig. 97 : Détail de la tranchée 3 et de l'organisation en cascade des bâtiments (photo : A. Waters). 


\section{PUBLICATIONS, CONFERENCES ET LECTURES (2012/2013)}

Nous présentons ci-dessous un récapitulatif des publications et communications qui ont eu trait à Labraunda entre décembre 2012 et janvier 2014.

\section{Volume paru}

L. Karlsson, S. Carlsson et J. Blid Kullberg (éds.), LABRYS, Studies presented to Pontus Hellstrom [Boreas 35], Uppsala, 2013.

Articles publiés

O. Henry, L. Karlsson and J. Blid, "Labraunda 2011", KST 34.2 : 455-471.

Olivier Henry et al., "Labraunda 2012 - Rapport préliminaire", Anatolia Antiqua XXI, 2013, 285-355.

Olivier Henry, "Tombes cariennes, tombes lyciennes : un processus analogue de pétrification architecturale?", in P. Brun, L. Cavalier, K. Konuk et Fr. Prost (dir.), EUPLOIA. La Lycie et la Carie antiques. Dynamiques des territoires, échanges et identités. Actes du colloque de Bordeaux 5, 6, 7 novembre 2009, Bordeaux Ausonius : 257-268.

L. Karlsson, "Combining Architectural Orders at Labraunda: A political Statement?”, in O. Henry (éd.), 4th Century Karia; Defining a Karian Identity under the Hekatomnids [Varia Anatolica XXVIII], Istanbul, 2013 : 65-80.

Lars Karlsson, "The Hekatomnid Pottery from the recent excavations and the date of the Forts at Labraunda", in P. Brun, L. Cavalier, K. Konuk et Fr. Prost (dir.), EUPLOIA. La Lycie et la Carie antiques. Dynamiques des territoires, échanges et identités. Actes du colloque de Bordeaux 5, 6, 7 novembre 2009, Bordeaux Ausonius : 213-224.

\section{Articles à paraître}

Olivier Henry, "De l'ombre à la lumière, une étude de monumentalité funéraire autour du sanctuaire carien de Labraunda", in Proceedings of Greek Monumental Tombs, Berlin February 10-11, 2012.

Olivier Henry, "Labraunda 2012", KST 35.

Karlsson, L., Blid Kullberg, J., Vergnaud, B. and A. Freccero, "A preliminary report on the work at the sanctuary with a new reconstruction drawing of the sanctuary by Jesper Blid Kullberg and an appendix by Fredrik Tobin”, Opuscula 7, 2014.

Contributions dans des colloques internationaux 05/2013 : Olivier Henry, "Labraunda 2012, preliminary report”, Kazı Sonuçları Toplantısı, Muğla 25-30 May 2013.

09/2013 : Vasilica Lungu, "Hellenistic Pottery from Labraunda. Looking for a Carian facies", $1^{\text {st }}$ Conference: Traditions and Innovations: Tracking the Development of Pottery from the Late Classical to the Early Imperial Periods, organized by International Association for Research on Pottery of Hellenistic Period, Berlin, November $2013,7^{\text {th }}-10^{\text {th }}$.
11/2013 : "4e Rencontres d'Archéologie de l'IFEA" - Pontus Hellström, "The Archaic Temple Terrace at Labraunda. Excavations 1949-1953”.

- Olivier Henry, "A pre-Hekatomnid Mausoleum at Labraunda?".

- Lars Karlsson, "The cult of Kybele at Labraunda".

- Damien Aubriet, "Mylasa et la Crète : une histoire longue et complexe".

01/2014: Felipe Rojas, Linda Gosner and J. Andrew Dufton: "Turning Water into Stone: Ancient Architectural Practice and a New Monumental Fountain in Labraunda, Caria", AIA $115^{\text {th }}$ Annual Meeting, Chicago, January 2-5, 2014.

\section{Conférences et Séminaires}

12/2012: Damien Aubriet, “Apports de l'épigraphie grecque à la connaissance du sanctuaire de Zeus à Labraunda (Carie)", Séminaire de MASTER II/Doctorat, Université de Caen, 15 décembre 2012.

01/2013 : Damien Aubriet, “Art, programme politique et identité dans le monde grec : quelques réflexions sur le sanctuaire carien de Zeus à Labraunda", Conférence en Histoire grecque à l'Université d'Orléans, 23 janvier 2013.

02/2013 : Damien Aubriet, “Art et programme politique dans le monde grec : le cas du sanctuaire carien de Zeus Labraundos", séminaire d'épigraphie grecque de M. Costanzi, Ecole du Louvre, 18 février 2013.

06/2013 : Olivier Henry, "Tombes royales - tombes dynastiques d'Asie Mineure, un état des dernières recherches", INHA (exposition Mendel), Paris.

08/2013 : Olivier Henry, "Labraunda ve Hekatomnidler", Dibeklihan, Ortakent /Bodrum

09/2013: Olivier Henry, “Labraunda' daki Hekatomnid Mozolesi", Milashan Oteli, Milas/Muğla.

09/2013: Felipe Rojas, "Hypostyle Building at Labraunda", September 11, 2013, Brown University, Providence, RI.

12/2013 : Olivier Henry, "Le sanctuaire carien de Zeus Labraundos en Carie : une vitrine de la puissance hekatomnide", INHA (Séminaire Archéologie de la Cité grecque, Paris 1), Paris.

01/2014 : Baptiste Vergnaud, "Pétra près de Labraunda, une forteresse carienne aux époques hécatomnide et hellénistique", (Séminaires Ausonius), Institut Ausonius, Université Bordeaux Montaigne, 29 Janvier 2014.

\section{Tables rondes (Labraunda Day)}

11/2013 au Museum of mediterranean and near east antiquities (Medelhavsmuseet, Stockholm) : New perspectives at Labraunda

Lars Karlsson : Årets utgrävningar och arbeten i Labranda (This year's excavations and work at Labranda).

Agneta Freccero : Konservering av marmor i Labranda (Marble conservation at Labranda).

Fredrik Tobin : Exedran på tempel-terassen (The exedra on the temple terrace). 
Ragnar Hedlund : Utgrävningen i Brunnhusstoan (The excavation of the stoa on the M-terrace).

12/2013 au Swedish Research Institute in Istanbul (SRII) : Labraunda 2013, preliminary results:

Olivier Henry : Introduction and Remarks concerning the Labraunda Mausoleum.

Ömur Çakmaklı : A new Roman water complex in Labraunda.

Jesper Blid : New research on Building $M$ and the Temple Terrace in the Roman and Hellenistic periods.

Can Karavul : Jeofizik yöntemlerin Labraunda Antik Kutsal Alanı'nda uygulaması ve sonuçları.

Felipe Rojas : The Hypostyle Building of Labraunda: example of vernacular Karian monumental architecture.

Baptiste Vergnaud : Labraunda Lower Acropolis Excavation 2013.

\section{CONCLUSION}

Comme le lecteur aura pu le constater dans les lignes qui précèdent, la saison 2013 à Labraunda a été particulièrement fructueuse. Beaucoup reste encore à faire, en terme de recherche autant que de mise en valeur du site et de protection/restauration. Nous attendons à cet égard avec impatience l'autorisation du Kurul de Muğla qui nous permettra de mettre en route le projet de restauration de l'Andron A. Le travail actuellement mené sur le nettoyage et la protection des marbres est en train de s'inscrire au sein d'un partenariat que nous souhaitons conclure avec le département de restauration de l'Université d'Uppsala, qui permettrait à la fois de pérenniser cette entreprise tout en participant à la formation des étudiants étrangers et locaux.

L'enseignement principal des travaux de documentation et de fouille de l'année 2013 tient probablement dans l'importance de l'activité architecturale du début de l'époque hellénistique. Qu'il s'agisse de l'acropole, du bâtiment en $P i$ sous la tombe monumentale, de la terrasse $\mathrm{M}$ ou encore du bâtiment hypostyle, tous ces chantiers démontrent que l'activité de construction n'a pas subi le contrecoup de la disparition des dynastes hékatomnides. Bien au contraire, il semble que les autorités locales issues de Milas ou du pouvoir central aient cherché à continuer la mise en valeur du sanctuaire en y apportant de nouveaux aménagements tant à la périphérie du site qu'en son sein même. La cohérence des travaux entrepris à cette époque semble démontrer un soucis de continuité dont l'origine nous échappe mais qui pourrait s'inscrire dans la volonté de célébrer le passé proche du sanctuaire en soulignant la pérennité de l'importance de ce centre régional et du culte local qui pourrait avoir été agrémenté des éléments hékatomnides.

O.H. et al

\section{ANNEXE}

Catalogue du matériel de la fouille de la Terrasse M

\section{Catalogue of Str. 1}

\section{Pottery (Fig. 98)}

1. 2 fragments (first shown from both interior and exterior) of white-glazed ware coming from different vessels (Lab13 MT-1:P27 [exterior and interior] and P24)

Find-spot: Str. 1, NE sector.

Description: Rims-and-body fragments. The body is covered with white glaze, with blue (and sometimes green) decorations. The fabric is white and very hard and dense. MT-1:P27, H. $1.1 \mathrm{~cm}$, L. $3.5 \mathrm{~cm}$. MT-1:P24, H. $1.6 \mathrm{~cm}$, W. $2.5 \mathrm{~cm}$.

Date: Mid- to late Ottoman (this ceramic is currently being processed).

2. 3 fragments of green-glazed ware, probably from the same vessel (Lab13 MT-1:P15, 1:P19, and 1:P17)

Find-spot: Str. 1.

Fabric: Light yellowish-red, medium-hard fabric.

Description: Rims-and-body fragments. The sherds are covered with a thick, light-greenish slip, with patchy areas of darker, greenish slip. The fragments show traces of sgrafitto decoration (calligraphy?). 1:P15, H. $3 \mathrm{~cm}, \mathrm{~W}$.
4.9 cm. 1:P19, H. $1.8 \mathrm{~cm}$, W. $3.2 \mathrm{~cm} .1: P 17$, H. $2.3 \mathrm{~cm}$, W. $3.7 \mathrm{~cm}$.

Date: Early Ottoman? (this ceramic is currently being processed).

3. 2 fragments of glazed bowl, probably from the same vessel (Lab13 MT-1:P04a-b.)

Find-spot: Str. 1, NE sector.

Fabric: Medium-hard, reddish-brown paste with very small mica inclusions.

Description: Body-base fragments. Amber coloured glaze preserved on interior. 1:P04a, H. $2.4 \mathrm{~cm}$, W. 5.3 cm. 1:P04b, H. $3.1 \mathrm{~cm}$, W. $3.3 \mathrm{~cm}$.

Date: Middle Byzantine ? (this ceramic is currently being processed).

Marbles (Fig. 99)

4. White marble revetment with meander frieze (M2013-13)

Find-spot: found in topsoil of NE sector.

Description: partly preserved fragment of meander, H. $17.2 \mathrm{~cm}$, W. $15.8 \mathrm{~cm}$. 

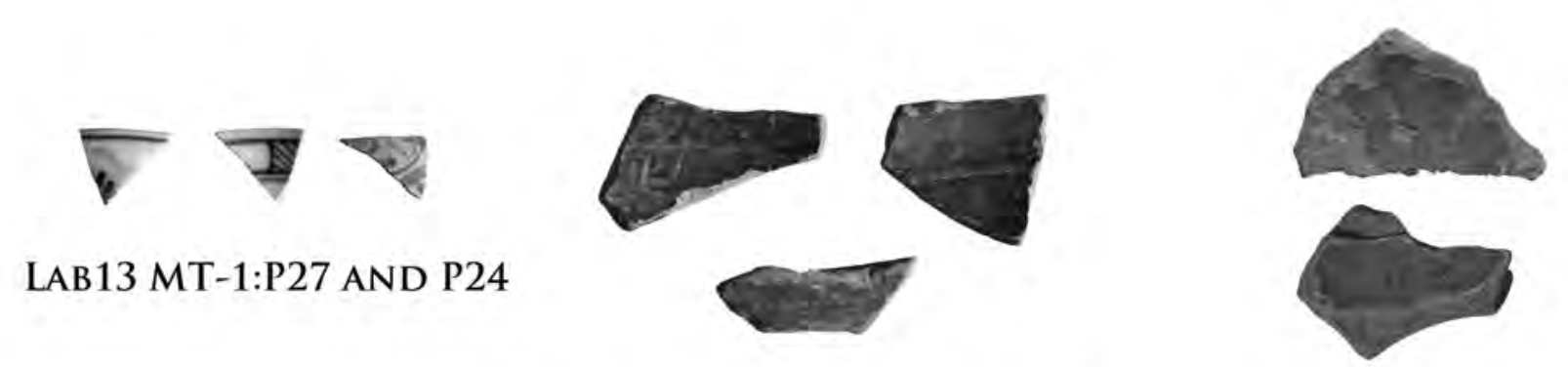

LAB13 MT-1:P15, 1:P19, AND 1:P17 LAB13 MT-1:P04A-B

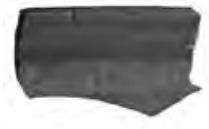

(LAB13 MT-2:P04)

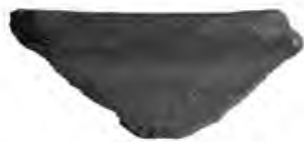

(LAB13 MT-3:P05)

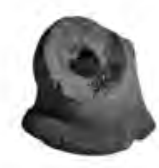

(LAB13 MT-4:P26)

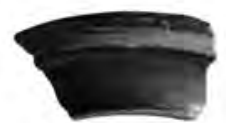

(LAB13 MT5:P28)

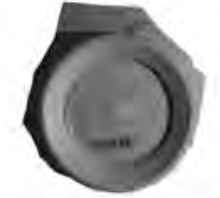

(LAB13 MT-4:P15)

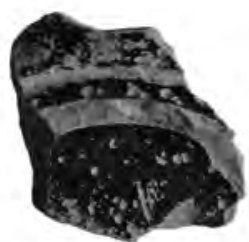

(LAB13 MT5:P04)

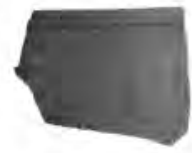

(LAB13 MT-4:P17)

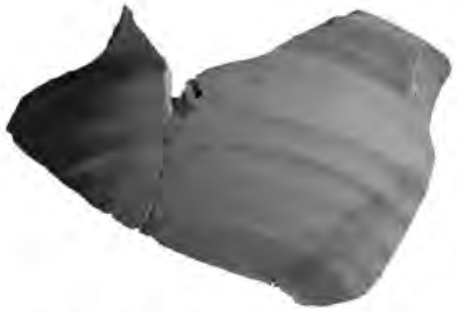

(LAB13 MT5:P38-2)

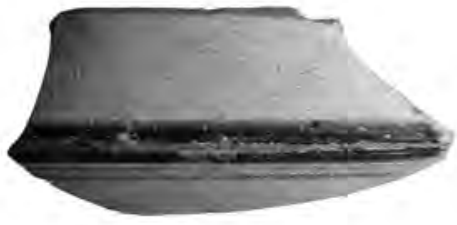

(LAB13 MT-5:P28)

Fig. 98: Selection of pottery from Trench M1 (J. Blid \& R. Hedlund). 

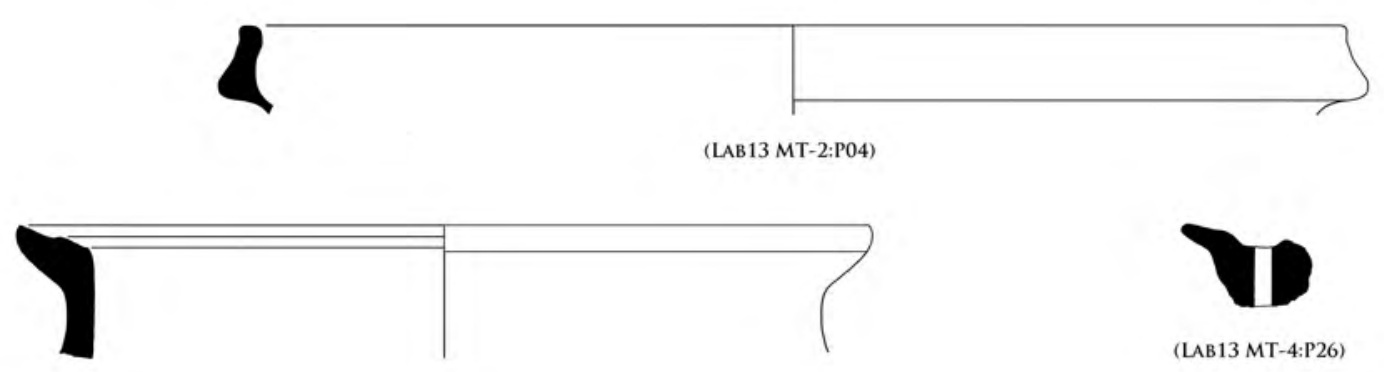

(LAB13 MT-4:P26)

(LAB13 MT-3:P05)

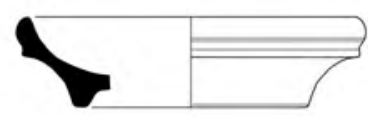

(LAB13 MT5:P28)
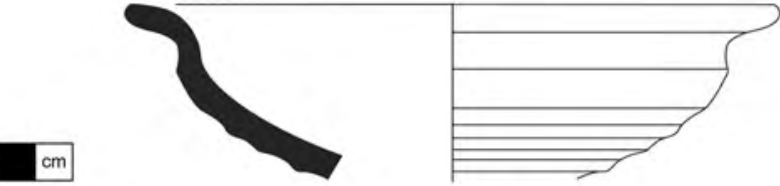

(LAB13 MT5:P38-2)
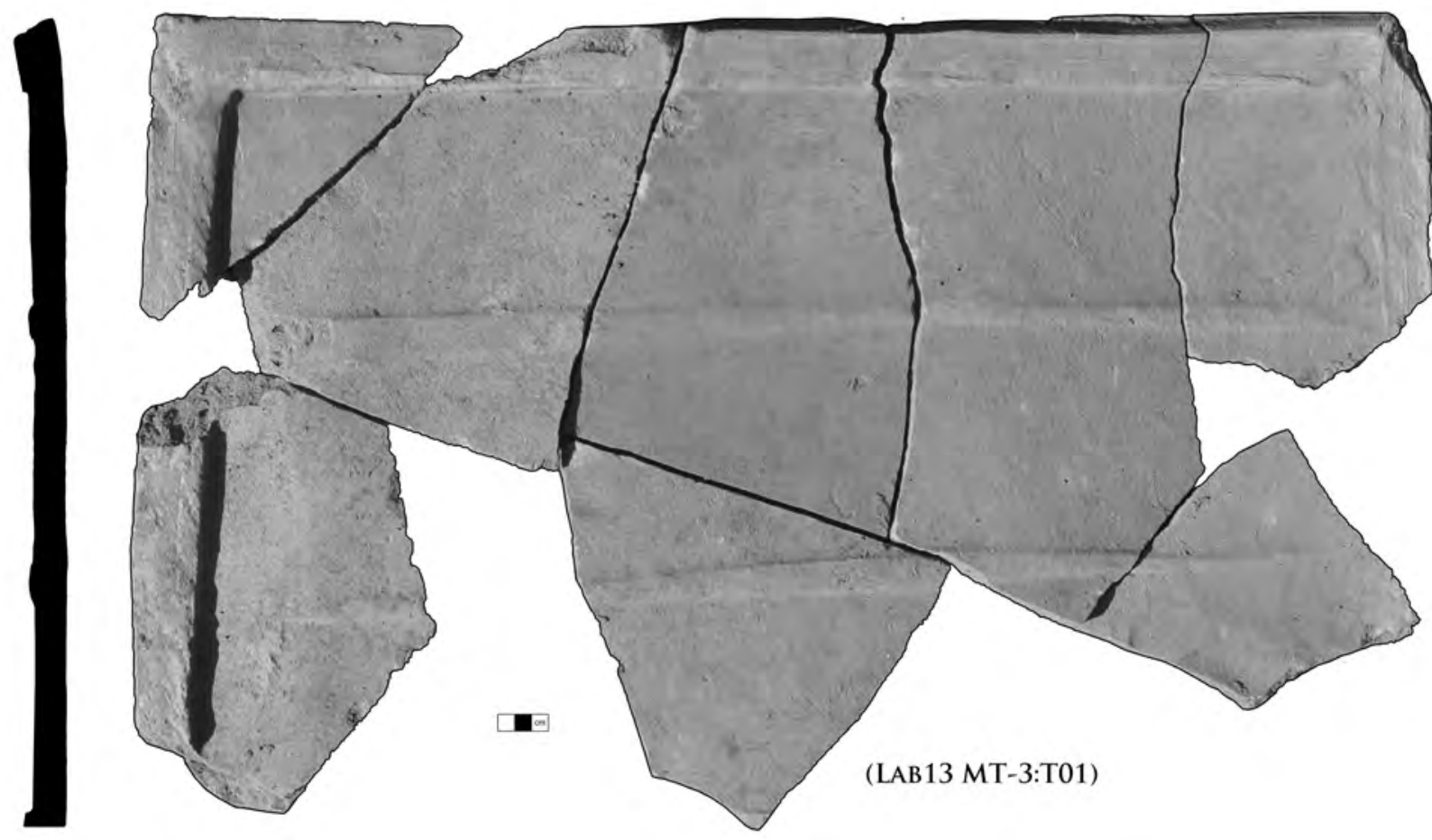

Fig. 99: Selection of pottery and roof tiles from Trench M1 (J. Blid \& R. Hedlund).

Date: Early $2^{\text {nd }}$ century A.D. (?) $)^{71}$.

Catalogue of Str. $2 \& 2 \mathrm{~B}$

Pottery (Fig. 98-99) 2:P04)

5. Dish of Phocaean Red Slip ware (Lab13 MT-

Find-spot: Str. 2B, SE sector.

Fabric: 10 R 6/8, light red. Fine, hard fabric without inclusions.
Description: Rim-to-body. No preserved traces of stamped decoration. Ø $30 \mathrm{~cm}, \mathrm{H} .2 .5 \mathrm{~cm}, \mathrm{~L} .4 .7 \mathrm{~cm}$.

Date: $5^{\text {th }}-6^{\text {th }}$ century A.D. ${ }^{72}$

Marbles (Fig. 100)

6. Corinthian pilaster capital in white marble (M20139)

Find-spot: Str. 2, NE sector.

71) This is most probably another fragment of the frieze that has previously been published by Gunter; $c f$. Labraunda II:5 : $44-51$ (cat. nos 18a-18u), Figs. 23-24.

72) Hayes $1972: 329-338$ (Form 3). 
Description: Corner of Corinthian pilaster capital with one preserved acanthus leaf supporting a volute. Partly preserved abacus. H. $24 \mathrm{~cm}, \mathrm{~W} .13 .6 \mathrm{~cm}$.

Date: Early $2^{\text {nd }}$ century A.D. (?).

7. White marble revetment with egg-and-dart moulding (M2013-10)

Find-spot: Str. 2.

Description: The fragment has two preserved eggs and darts and part of a flat crowning moulding. H. 10.4 $\mathrm{cm}, \mathrm{W} .13 .6 \mathrm{~cm}$.

Date: Early $2^{\text {nd }}$ century A.D. (?).

8. White marble revetment with lotus-and-palmette frieze (M2013-12)

Find-spot: Str. 2.

Description: The fragment has a partly preserved palmette and the vey faint remains of a lotus flower. $\mathrm{H}$. $12 \mathrm{~cm}, \mathrm{~W} .16 .4 \mathrm{~cm}$.

Date: Early $2^{\text {nd }}$ century A.D. (?).

Catalogue of Str. $3 \& 3 \mathrm{~B}$

Pottery and roof tiles (Fig. 98-99)

9. Cooking pot (Lab13 MT-3:P05)

Find-spot: Str. 3B, SE sector.

Fabric: $10 \mathrm{R} \mathrm{4/6}$, red. Coarse paste with miss-fired core. Few, ca. $1 \mathrm{~mm}$ large, angular white and black inclusions.

Description: Rim-to-body. Coarse kitchen ware, rimto-base, $\varnothing 23 \mathrm{~cm}$, H. $3.5 \mathrm{~cm}$, L. $9.1 \mathrm{~cm}$.

Date: Mid-to second half of $5^{\text {th }}$ century A.D. ${ }^{73}$

10. Roof tile (Lab13 MT-3:T01)

Find-spot: Str. 3B, SE sector.

Fabric: Reddish-yellow clay with very small inclusions of mica, $c a$. $10-15$ per $1 \mathrm{~cm}^{2}$.

Description: H. $74 \mathrm{~cm}$, W. $48 \mathrm{~cm}$.

Coin (Fig. 100)

11. Bronze coin of Constantine 1 (Lab13-MT010)

Find-spot: Str. 3B, just north-east of threshold of Door 1.

Description: type probably Sarmatia Devicta or Alamannia Devicta. Obv: Head of emperor, laur. Legend: CONSTANTINVS AVG. Rev: Victoria, advancing r., holding trophy and palm branch (?), spurning captive on ground. Legend: missing. Ø $1.4 \mathrm{~cm}$.

Date: A.D. $323-324^{74}$.

\section{Catalogue of Str. 4}

Pottery (Fig. 98-99)

12. 'Frying pan' (Lab13 MT-4:P26)

Find-spot: Str. 4.

Fabric: 2.5 YR 3/4, dark reddish brown. Coarse paste. Less than $10 \mathrm{ca} .1 \mathrm{~mm}$ large inclusions per $1 \mathrm{~cm}^{2}$.

Description: hollow handle of coarse kitchen ware, $\varnothing$ (of handle) $5 \mathrm{~cm}$, H. $2.3 \mathrm{~cm}$, L. $3.8 \mathrm{~cm}$

Date: $1^{\text {st }}-2^{\text {nd }}$ century A.D. ${ }^{75}$

13. Knidian thin-walled ware (Lab13 MT-4:P15) Find-spot: Str. 4.

Fabric: 7.5 YR 7/6, reddish yellow. Fine, hard fabric with no inclusions. Slip on interior, 2.5 YR 3/4, dark reddish brown.

Description: Body-to-base. The most common type of early-imperial fine wares found at Labraunda. $\varnothing$ (of ring base) $4.4 \mathrm{~cm}$, H. $1.5 \mathrm{~cm}$, L. $3.4 \mathrm{~cm}$.

Date: $1^{\text {st }}-2^{\text {nd }}$ century A.D. ${ }^{76}$

14. Local imitation (?) of Pergamene sigillata (Lab13 MT-4:P17)

Find-spot: Str. 4.

Fabric: 5 YR 6/6, reddish yellow. Fine, hard fabric with very small mica inclusions.

Description: Rim-to-body. Red slip on interior $10 \mathrm{R}$ 4/8. Ø $13 \mathrm{~cm}$, H. $3.6 \mathrm{~cm}$, L. $4.7 \mathrm{~cm}$.

Date: $1^{\text {st }}-2^{\text {nd }}$ century A.D. ${ }^{77}$

Metal (Fig. 100)

15. Iron handle from Door 3 ? (Lab13 MT009-2)

Find-spot: Str. 4 at Door 3.

Description: Corroded iron handle. L. $13.5 \mathrm{~cm}$.

\section{Catalogue of Str. 5}

Pottery (Fig. 98-99)

16. Black-gloss bowl with shallow wall and convexconcave profile (Lab13 MT5:P28)

Find-spot: Str. 5 (bottom of stratum), in the area of Door 3.

Fabric: 2.5 YR 6/8, light red. Very hard paste covered by black slip.

Description: Rim-to-base, Ø $9.5 \mathrm{~cm}, \varnothing 3.4 \mathrm{~cm}$ (of ring base) $9.5 \mathrm{~cm}$, H. $2.4 \mathrm{~cm}$, L. $5.5 \mathrm{~cm}$.

Date: $425-400$ B. $C^{78}$

73) Blid $2012: c f$. the Tetraconch, cat. $\mathrm{n}^{\text {os }} 59-64$, the West Church Complex, cat. $\mathrm{n}^{\text {os }} 15-16$; Poulter et al. 1999: 155-156, fig 9.15 (cat. $\mathrm{n}^{\circ}$ 274); Turnovsky $2005: 640$ (cat. $\mathrm{n}^{\circ}$ 7).

74) RIC VII : e.g. 201, cat. $\mathrm{n}^{\text {os }} 429$ or 475 , cat. $\mathrm{n}^{\text {os }} 49-51$

75) Gasperetti 2003 : 154, cat. no. 56 (pl. XCVII).

76) Agora XXXII : Cat. n 1619 (Knidian ware); Labraunda II:1 : 38f (Brittle ware); Samos XIV : 162

77) Cf. Athenian Agora XXXII : cat. ${ }^{\circ} 770$ (fig. 24).

78) Athenian Agora XII, 224 (cat. no 819). 


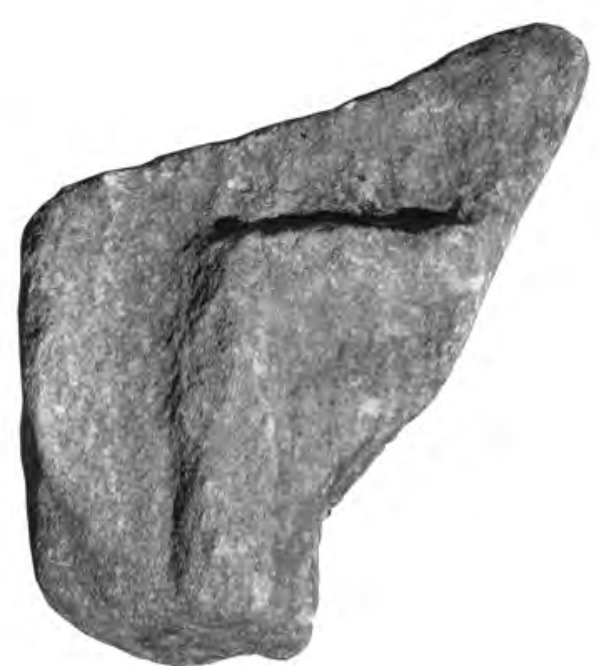

M2013-13

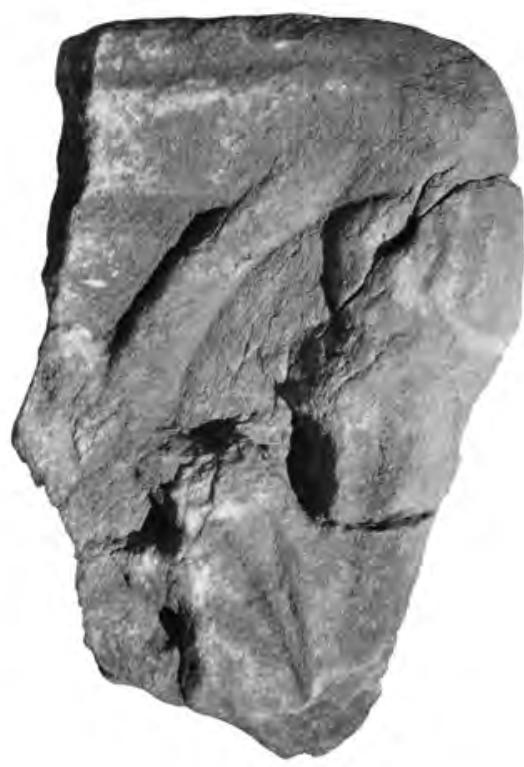

M2013-9

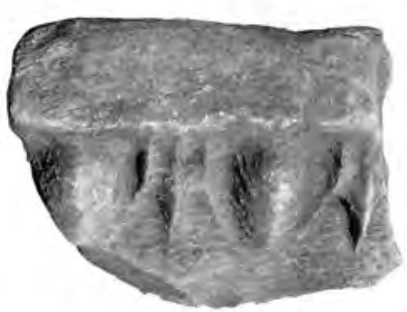

M2013-10

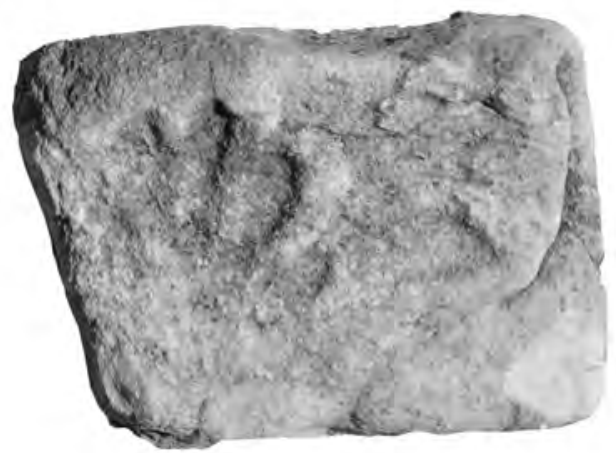

M2013-12
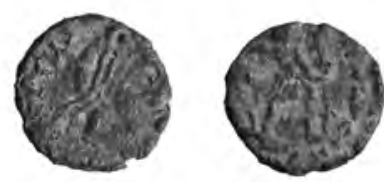

LAB13-MT010

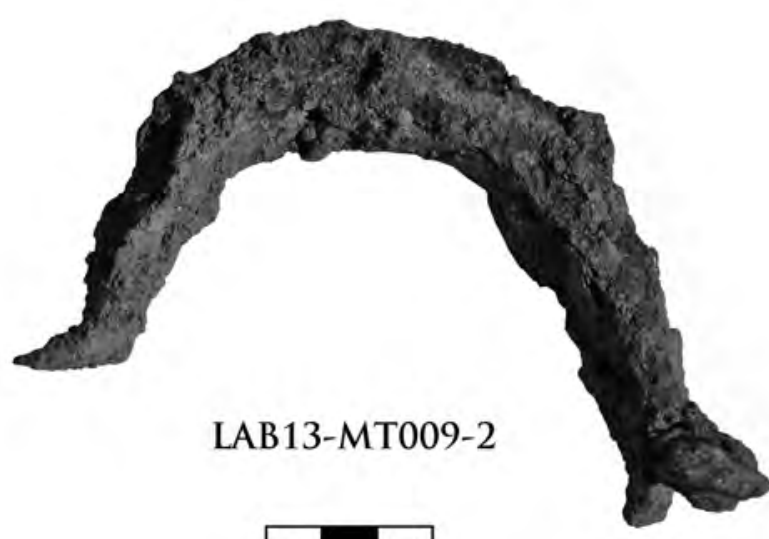

$\mathrm{cm}$

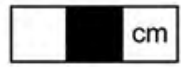

Fig. 100: Selection of marble and metal finds from Trench M1 (J. Blid \& R. Hedlund). 
17. Black-gloss Bolsal (Lab13 MT5:P04)

Find-spot: Str. 5 (bottom of stratum), NE sector.

Fabric: 7.5 YR 7/6, reddish yellow.

Description: Body-to-base. Very hard, fine paste with few, small inclusions. Interior and exterior is covered by black slip. 3 rouletted tondi in centre of the interior. $\mathrm{H}$. $1.9 \mathrm{~cm}$, L. $6.2 \mathrm{~cm}$.

Date: $380-350$ B.C. ${ }^{79}$

18. Terracotta figurine, hydrophoros? (Lab13 MT5:P27)

Find-spot: Str. 5 (bottom of stratum), in the area of Door 3.

Fabric: 5 YR 6/8, reddish yellow. Medium-hard, grainy fabric with $10-15$ very small mica inclusions per 1 $\mathrm{cm}^{2}$.

Description: Section of waist and left leg covered by convoluted drapery. H. $5.7 \mathrm{~cm}$, W. $3.1 \mathrm{~cm}$.

Date: $5^{\text {th }}$ century B.C. ${ }^{80}$
19. Achaemenid bowl/phiale (Lab13 MT5:P38-2)

Find-spot: Str. 5 (at the level of footing course), in the area of Door 3. One of five vessels identified.

Fabric: Coarse paste, buff, buff dark, or buff orange fabric, with some mica and fine limestone inclusions, with small holes in section.

Description: Rim-to-body. Ribbed exterior of wall. $\varnothing 17.5 \mathrm{~cm}$, H. $4.6 \mathrm{~cm}$.

Date: Mid- $3^{\text {rd }}$ century B.C. ${ }^{81}$

20. Lagynos [pitcher] (Lab13 MT-5:P28)

Find-spot: Str. 5 (found in the very upper section of this stratum, close to Str. 4).

Fabric: 10 R 7/8, light red. Fine, hard fabric with no inclusions.

Description: Body fragment. White slip with dark yellow and brownish red bands on exterior of body. $\mathrm{H}$. $4.5 \mathrm{~cm}$, L. $9.5 \mathrm{~cm}$.

Date: Late $2^{\text {nd }}$-early $1^{\text {st }}$ century B.C.

\section{BIBLIOGRAPHIE} Paris.

Adam, J.-P., 1982 : L'architecture militaire grecque, Paris.

Akarca, A., 1959 : Les monnaies grecques de Mylasa,

Athenian Agora XII : Sparkes, B.A. et Talcott, L., The Athenian Agora. Results of excavations conducted by the American School of Classical Studies at Athens XII:1-2. Black and plain pottery of the $6^{\text {th }}, 5^{\text {th }}$ and $4^{\text {th }}$ centuries B.C., Princeton, NJ, 1970.

Athenian Agora XXXII : Hayes, J., The Athenian Agora. Results of excavations conducted by the American School of Classical Studies at Athens, XXXII. Roman pottery: fine-ware imports, Princeton, NJ, 2008.

Athenian Agora XXXIV : Weinberg, G.D. et Stern, E.M., The Athenian Agora. Results of excavations conducted by the American School of Classical Studies at Athens, XXXIV. Vessel glass, Princeton, NJ, 2009.

Blid, J., 2012 : Felicium Temporum Reparatio. Labraunda in Late Antiquity (c. AD 300-600), Stockholm.

Blid Kullberg, J., 2014 : "Flowers and garlands of the alsos: verdant themes within the architectural sculpture of Labraunda", in Karlsson, L., Carlsson, S. et Blid

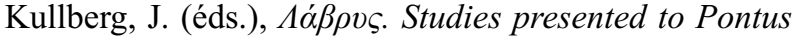
Hellström, [BOREAS 35], Uppsala : 19-42.

Brun, P., 1994 : "Les fortifications d'Hyllarima, Philon de Byzance et Pleistarchos", in Debord, P. et Descat, R. (éds.), Fortifications et défense du territoire en Asie Mineure occidentale et méridionale. Table ronde CNRS, Istanbul 20-27 mai 1993, [REA 96] : 193-204.
Debord, P. et Varinlioğlu, E., 2011 : Cités de Carie, Harpasa, Bargasa, Orthosia dans l'Antiquité, PUR, Rennes.

Deppert-Lippitz, B., 1984 : Die Münzprägung Milets vom vierten bis ersten Jahrhundert v. Chr., Aarau.

Fachard, S., 2012 : La défense du territoire. Etude de la chôra érétrienne et de ses fortifications [Eretria XXI], Gollion.

Gasperetti, G., 2003 : “Osservazioni preliminari sulla ceramica romana di Iasos di Caria. Materiali dal quartiere a sud del teatro", in Abadie-Reynal, C. (éd.), Varia Anatolica XV: Les céramiques en Anatolie aux époques hellénistique et romaine, Istanbul 2003 : 141-156.

Grandjean, Y., 2011 : Le rempart de Thasos (avec la collaboration de Wurch-Kozelj, M. et la participation de Kozelj, T.), [Etudes Thasiennes XXII], Athènes.

Halikarnassos 7 : Vaag, L.E., Norskov, V. et Lund, J., The Maussolleion at Halikarnassos, Reports of the Danish Archaeological Expedition to Bodrum 7. The pottery. Ceramic material and other finds from selected contexts, Aarhus 2002.

Hayes, J.W., 1972 : Late Roman pottery, London.

Hedlund, R., 2014 : "Antae in the afternoon. Notes on the Hellenistic and Roman architecture of Labraunda", in Karlsson, L., Carlsson, S. et Blid Kullberg, J. (éds.),

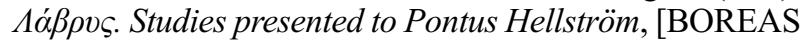
35], Uppsala : 57-70.

79) Agora XII:1 : 275 and Agora XII:2 : fig. 6 (Cat. n ${ }^{\circ}$ 561); Olynthus V : 153 and pl. 123 (Cat. n 273); Olynthus XIII : 329 and pl. 213 (Cat. $\mathrm{n}^{\circ}$ 659); Halikarnassos 7 : 216 and pl. 54 (Cat. ${ }^{\circ}$ L39).

80) Karlsson $2014: 87-91$.

81) The fragments were found together with a rim of a Koan type amphora, of which a similar discovery from Egypte-Tebtynis is dated to the middle of the $3^{\text {rd }}$ century B.C. (information given by the ceramologist of the project, Vasilica Lungu). 
Hellström, P., 2007 : Labraunda: A Guide to the Karian Sanctuary of Zeus Labraundos, Istanbul.

Henry et al. 2013 : "Labraunda 2012 - Rapport préliminaire", Anatolia Antiqua XXI : 285-355.

Hoffmann, A., 2000 : "Die Stadtmauern der Hellenistisch-Römischen Dekapolisstadt Gadara", $A A$ : 175233.

Jones, F., (éd.), 1950 : Excavations at Gözlü Kule, Tarsus, I, The Hellenistic and Roman Periods, Princeton, NJ.

Karlsson, L., 2010 : “Labraunda 2009. A preliminary report on the Swedish excavations with contributions by Jesper Blid \& Olivier Henry", Opuscula 3 : 61-104.

Karlsson, L., 2011 : "The forts and fortifications of Labraunda", in Karlsson, L. et Carlsson, S. (éds.), Labraunda and Karia, Proceedings of the international symposium commemorating sixty years of Swedish archaeological work in Labraunda. The Royal Academy of Letters, History and Antiquities, Stockholm, 20-21 Novembre 2008 [BOREAS 32] : 217-252.

Karlsson, L., 2014 : "The Labraunda hydrophoroi”, in Karlsson, L., Carlsson, S. et Blid Kullberg, J. (éds.),

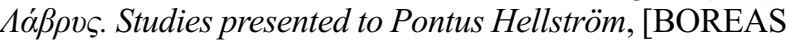
35], Uppsala : 87-91,

Karlsson, L. et al., 2010 : "Labraunda 2009, a preliminary report on the Swedish excavations", Opuscula 3 : 61-104.

- 2011 : "Labraunda 2010, a preliminary report on the Swedish excavations", Opuscula 4 : 21-67.

- 2012 : "Labraunda 2011, a preliminary report on the Swedish excavations", Opuscula 5 : 49-87.

- 2014 : "Labraunda 2012-2013. A preliminary report on the work at the sanctuary with a new reconstruction drawing of the sanctuary by Jesper Blid Kullberg and an appendix by Fredrik Tobin", Opuscula 7 : 2014.

Kienast, H.J., 1978 : Die Stadtmauer von Samos, Bonn.

Labraunda II:1 : Hellström, P., Labraunda, Swedish excavations and researches II:1. Pottery of Classical and later date, terracotta lamps and glass [ActaAth-4 $\left.{ }^{\circ}, 5: 2: 1\right]$, Lund 1965.

Labraunda II:5 : Gunter, A. C., Labraunda: Swedish Excavations and Researches, II.5. Marble sculpture, Stockholm 1995.

Labraunda III:2 : Crampa, J., Labraunda: Swedish Excavations and Researches, III.2. The Greek Inscriptions, part 2, 13-133, [ActaAth-4 , 5:3:2], Stockholm 1972.

Laumonier, A., 1936 : “Archéologie carienne", $\mathrm{BCH}$ $60: 286-335$.
Liljenstolpe, P. et von Schmalensee, P., 1996 : “The Roman stoa of Poleites at Labraynda. A report on its architecture", OpAth $21: 125-148$.

McNicoll, A.W., 1997 : Hellenistic fortifications from the Aegean to the Euphrates, Oxford.

Morris, S.P. and Papadopoulos, J.K., 2005 : "Greek Towers and Slaves: An Archaeology of Exploitation", AJA 109 : 155-225.

Olynthus V : Robinson, D.M., Excavations at Olynthus V. Mosaics, vases, and lamps of Olynthus found in 1928 and 1931, Baltimore \& London 1933.

Olynthus XIII : Robinson, D.M., Excavations at Olynthus XIII. Vases found in 1934 and 1938, Baltimore \& London 1950.

Pimouguet-Pédarros, I., 2000 : Archéologie de la défense: Histoire des fortifications antiques de Carie aux époques classique et hellénistique, Paris.

Poulter, A.G., Falkner, R.K. et Shepherd, J.D., 1999 : Nicopolis ad Istrum: a Roman to Early Byzantine city. The pottery and glass, London.

RIC VII : Bruun, P.M., The Roman imperial coinage, 7: Constantine and Licinius, A.D. 313-337, (RIC 7), éds. Sutherland, C.H.V., Litt, D. et Carson, R.A.G., London 1966.

Rotroff, S., 1983 : "Three Cistern Systems on the Kolonos Agoraios", Hesperia 52.3 : 257-297.

- 1997 : Hellenistic Pottery Athenian and Imported wheelmade table ware and related material, [Athenian Agora XXIX], Princeton, New Jersey.

Samos XIV : Tölle-Kastenbein, R., Samos XIV. Das Kastro Tigani: die Bauten und Funde griechischer, römischer und byzantinischer Zeit, Bonn 1974.

Turnovsky, P., 2005 : "The morphological repertory of Late Roman/Early Byzantine coarse wares in Ephesos", in Gurt i Esparraguera, J.M., Buxeda i Garrigós, J. et Cau Ontiveros, M.A. (éds.), Late Roman coarse wares, cooking wares and amphorae in the Mediterranean: archaeology and archaeometry, Oxford : 635-654.

Vergnaud, B., 2014 : "Quelques observations sur la forteresse de Labraunda", in Karlsson, L., Carlsson, S. et Blid Kullberg, J. (éds.), $\Lambda \alpha ́ \beta \rho v \varsigma$. Studies presented to Pontus Hellström, [BOREAS 35], Uppsala : 107-122.

- 2013 : "L'acropole du site", in Henry, O. et al., "Labraunda 2012, rapport préliminaire", Anatolia Antiqua XXI : 285-298.

Von Gerkan, A., 1935 : Milet II.3. Die Stadtmauern, Berlin. 



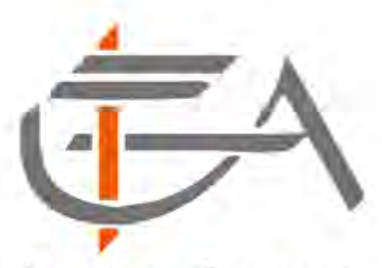

Institut Francais

d'Etudes Anatoliennes

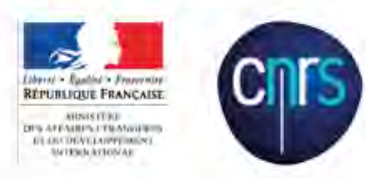

Peinture rupestre préhistorique, Sağlık Köy, près d'Alabanda, Turquie (cliché Suat Ateşlier). 